
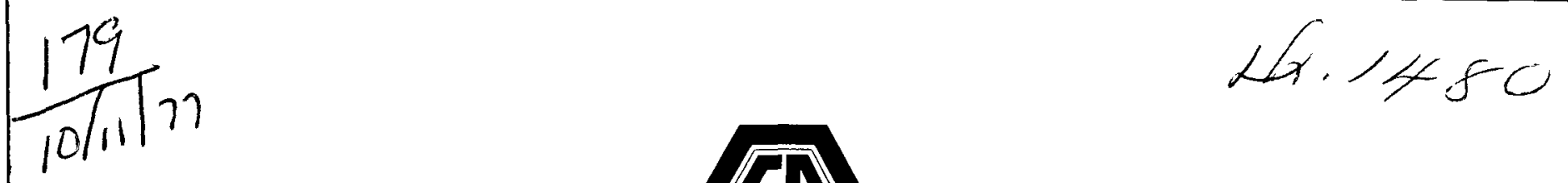

\author{
GA-A 14320

\section{REPROCESSING YIELDS AND MATERIAL THROUGHPUT - HTGR RECYCLE DEMONSTRATION FACILITY}

UC-77

\author{
by \\ N. HOLDER and L. ABRAHAM
}

Prepared under

Contract EY-76-C-03-0167

Project Agreement No. 53

for the San Francisco Operations Office

U.S. Energy Research and Development Administration 


\title{
NOTICE
}

This report was prepared as an account of work sponsored by the Lnited States Government Netther the Unted States nor the United States Fnergy Resedrch and Developinent Admınıstration, nol any of theil emplovees nor any of theil contractors, subcontractors or their employees makes iny warranty express or implied or assumes any legal liability or responsibility for the accuracy completeness or usefulness of any information, apparatus product or process disclosed or icpresents that its use would not infringe privately owned rights

\author{
Printed in the United States of America \\ Available from \\ National Technical Information Service \\ U.S. Department of Commerce \\ 5285 Port Roya 1 Road \\ Springfield, Virginia 22161 \\ Price: Printed Copy $\$$; Microfiche $\$ 3.00$ \\ 6.50
}




\section{DISCLAIMER}

This report was prepared as an account of work sponsored by an agency of the United States Government. Neither the United States Government nor any agency Thereof, nor any of their employees, makes any warranty, express or implied, or assumes any legal liability or responsibility for the accuracy, completeness, or usefulness of any information, apparatus, product, or process disclosed, or represents that its use would not infringe privately owned rights. Reference herein to any specific commercial product, process, or service by trade name, trademark, manufacturer, or otherwise does not necessarily constitute or imply its endorsement, recommendation, or favoring by the United States Government or any agency thereof. The views and opinions of authors expressed herein do not necessarily state or reflect those of the United States Government or any agency thereof. 


\section{DISCLAIMER}

Portions of this document may be illegible in electronic image products. Images are produced from the best available original document. 


\section{REPROCESSING YIELDS AND MATERIAL THROUGHPUT - HTGR RECYCLE DEMONSTRATION FACILITY}

by

N. HOLDER and L. ABRAHAM

\section{Prepared under}

Contract EY-76-C-03-0167

Project Agreement No. 53

for the San Francisco Operations Office

U.S. Energy Research and Development Administration

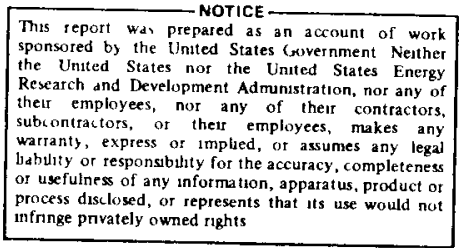


0. 
ABSTRACT

Recovery and reuse of residual U-235 and bred U-233 from the HighTemperature Gas-Cooled Reactor (HTGR) thorium-uranium fuel cycle will contribute significantly to HTGR fuel cycle economics and to uranium resource conservation. The Thorium Utilization National Program Plan for HTGR Fuel Recycle Development includes the demonstration, on a production scale, of reprocessing and refabrication processes in an HTGR Recycle Demonstration Facility (HRDF).

This report addresses process yields and material throughput that may be typically expected in the reprocessing of highly enriched uranium fuels in the HRDF. Material flows will serve as guidance in conceptual design of the reprocessing portion of the HRDF. In addition, uranium loss projections, particle breakage limits, and decontamination factor requirements are identified to serve as guidance to the HTGR fuel reprocessing development program. 
•

• 
CONTENTS

ABSTRACT . . . . . . . . . . . . . . . . . . . 1 . . . . . .

1. INTRODUCTION . . . . . . . . . . . . . . . . . 1

References... . . . . . . . . . . . . 6

2. REPROCESSING FEED MATERIAL DEFINITION. . . . . . . . . . . . 7

2.1. Fuel Element Types . . . . . . . . . . . . . . . . 7

2.2. Fuel Element Composition . . . . . . . . . . . . 10

2.3. Feed Material Variations . . . . . . . . . . . . 13

2.4. Yields and Material Balance Basis. . . . . . . . . 15

References . . . . . . . . . . . . . . . . 18

3. PROCESS YIELDS AND MATERIAL THROUGHPUT . . . . . . . . 27

3.1. Reprocessing Flow Diagram and Material Balance

Description. . . . . . . . . . . . . . . 27

3.2. Unit Operation Yields and Throughput - Head-End. . . . . 29

3.2.1. Fuel Element Crushing. . . . . . . . . . 31

3.2.2. Material Transport (Solids). . . . . . . . 36

3.2.3. Fuel Element Burning . . . . . . . . . 40

3.2.4. Fuel Particle Separation (Classification). . . . 47

3.2.5. Fertile Fraction Leaching. . . . . . . . . 50

3.2.6. Fuel Particle Crushing and Burning . . . . . 57

3.2.7. Fissile Fraction Leaching. . . . . . . . . 61

3.2.8. Material Sampling. . . . . . . . . . . 67

3.3. Yields and Throughput Summary - Head-End Operations. . . 68

3.3.1. Reprocessing Throughput Summary. . . . . . . 68

3.3.2. Reprocessing Yields Summary. . . . . . . . 69

3.4. Yields and Material Throughput - Off-Gas Treatment . . . 82

3.5. Yields and Material Throughput - Solvent Extraction. • • 86

References ..................... 93

4. COMPARISON OF REPROCESSING YIELDS WITH PRODUCT SPECIFICATION . 98

References . . . . . . . . . . . . . . . 102 
FIGURES

1-1. Reference recycle design basis: once-through U-235 recycle, continuous $\mathrm{U}-233$ recycle . . . . . . . . . 2

1-2. HTGR coated fuel particles. . . . . . . . . . . . . 4

1-3. HTGR fuel reprocessing flow diagram . . . . . . . . . . 5

2-1. HTGR standard fuel element. . . . . . . . . . . . 8

2-2. HTGR control fuel element . . . . . . . . . . . . . 9

2-3. HRDF block flow comparisons (steam-cycle HTGR). . . . . . . 14

3-1. Reprocessing flow diagram . . . . . . . . . . . 28

3-2. Block diagram of fuel element crushing and material transport . . . . . . . . . . . . . . 32

3-3. Transport system routes and storage points. . . . . . . 37

3-4. Block diagram of fuel element burning and material transport .................... . 4 41

3-5. Block diagram of fuel particle classifying. . . . . . . 48

3-6. Block diagram of fertile fraction leaching. . . . . . . . . 51

3-7. Fissile fraction particle crushing and burning. . . . . . . 58

3-8. Block diagram of fissile fraction leaching. . . . . . . . 62

3-9. Crossover of fuel particles vs weight fraction of fissile particles . . . . . . . . . . . . . . . 73

3-10. Proposed reprocessing off-gas treatment scheme. . . . . . 83

3-11. Thorex solvent extraction diagram . . . . . . . . . . 89

3-12. Purex solvent extraction diagram. . . . . . . . . . . . 90

\section{TABLES}

2-1. HRDF reprocessing feed materials. . . . . . . . . . . 11

2-2. Average fuel element definitions - HRDF . . . . . . . . 12

2-3. Typical mix of spent fuel elements discharged from an 1160-MW (e) HTGR ................. 16

2-4. HTGR fuel element block flow for recycle. . . . . . . . . 17

2-5. Spent fuel element definition - (TBV) (average LHTGR standard makeup element; TRISO $\mathrm{UC}_{\mathrm{x}} \mathrm{O}_{\mathrm{y}}$ fissile; BISO $\mathrm{ThO}_{2}$ fertile) . . 20

2-6. Spent fuel element definition - (TBV) (average LHTGR recycle element; TRISO UC $\mathrm{O}_{\mathrm{y}}$ fissile; BISO Tho ${ }_{2}$ fertile). . . . . . 21 


\section{INTRODUCTION}

The High-Temperature Gas-Cooled Reactor (HTGR) operates on the thoriumuranium cycle utilizing 93\% U-235-enriched uranium as fissile fuel. The U-233 bred in the cycle is also an excellent fissile fuel, and its recovery and reuse (recycle) in the reactor will contribute significantly to HTGR fuel cycle economics and to uranium resource conservation.

The Thorium Utilization National Program Plan for HTGR Fuel Recycle Development states as a specific objective the provision of a demonstration plant for the recycle of HTGR fuels. The HTGR Fuel Recycle Demonstration Facility (HRDF) will demonstrate, on a production scale, processes that are licensable and commercially feasible for both recovery (reprocessing) and refabrication of spent fuels from HTGRs (Ref. 1-1).

This report specifically addresses process yields and material throughputs that may typically be expected in the reprocessing section of the HRDF. A companion report (Ref. 1-2) describes the processes in detail, including flow sheets and material balances, and outlines development recommendations for the HRDF. This report pertains to expected variations in the material flows to serve as guidance for HRDF reprocessing conceptual design and for the reprocessing development program.

The reference recycle design basis for the HRDF is illustrated schematically in Fig. 1-1. In addition to bred U-233 recovery, sufficient residual U-235 remains in the spent initial fissile material to make its recovery and reuse economically attractive. It is desirable, however, to recover and process the U-235 separately since a significant percent of neutron capture in the U-235 in the reactor leads to the formation of U-236, a neutron poison. Considerably less U-236 is formed with the bred U-233; recent HTGR spent fuel element definitions (Ref. 1-3) indicate that about $80 \%$ of the 


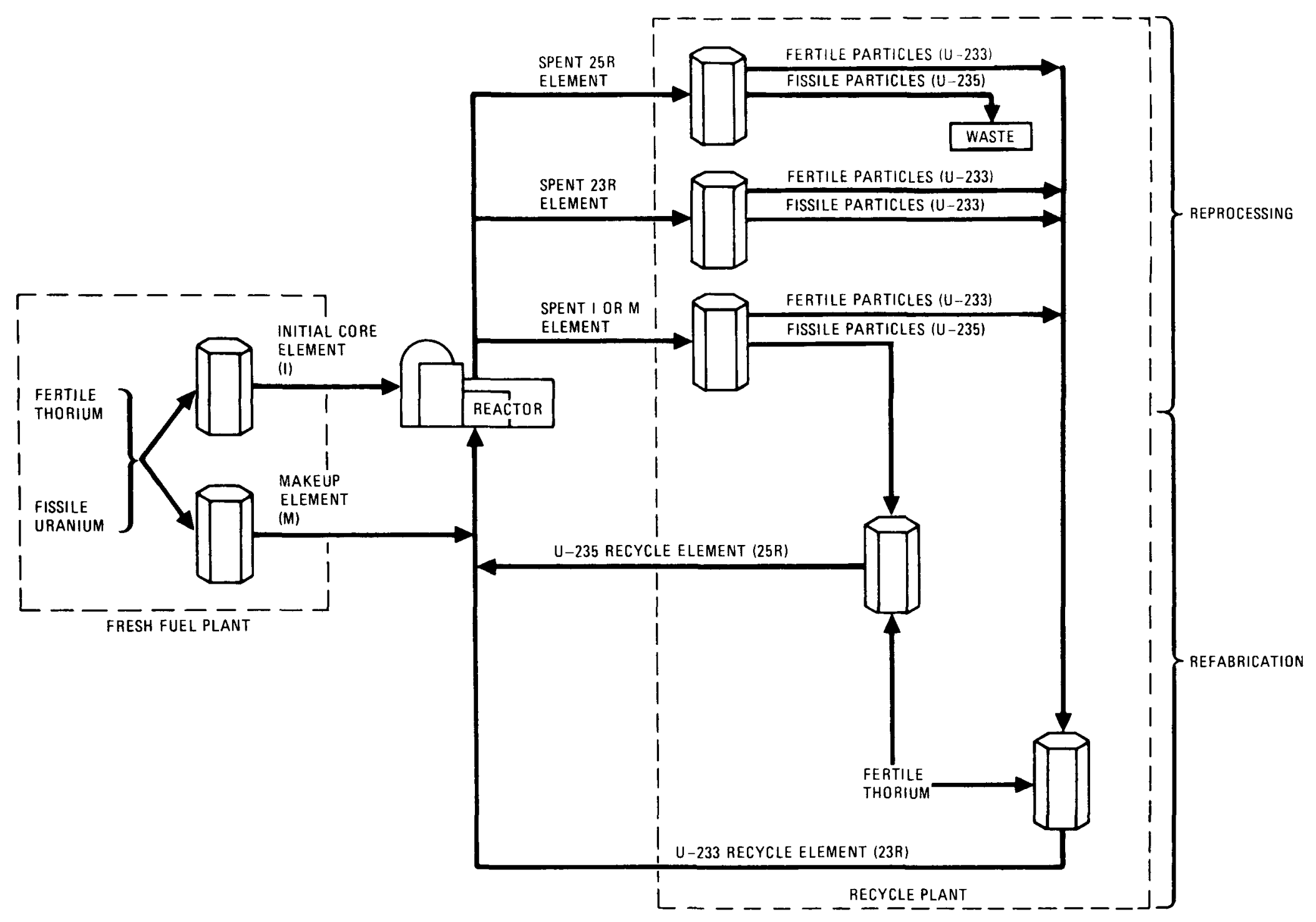

Fig. 1-1. Reference recycle design basis: once-through U-235 recycle, continuous U-233 recycle 
U-236 in the fuel element is associated with the spent fissile U-235 and about $20 \%$ with the bred U-233 in a typical full-burnup reactor segment. Economic analyses (Refs. 1-4 and 1-5) have indicated that the U-235 should be recycled at least once before removal from the fuel cycle.

The particulate nature of the proposed Large HTGR (LHTGR) fuel (Fig. 1-2) lends itself to the separation of the U-235 and U-233 during recycle. The TRISO-coated fissile fuel particle initially contains the 93\% U-235-enriched uranium and the BISO-coated fertile fuel particle initially contains the thorium. Separation techniques based on the coatings and on particle density allow separation of the particles for separate processing in the recycle plant. Similar particle configurations for refabricated fuel allow the separation of the depleted U-235 particles as waste when they are returned from the reactor in separately identified fuel elements.

The reprocessing processes consist basically of crushing and burning the hexagonal graphite fuel elements, freeing the fuel particles from the carbonaceous matrix fuel rods contained in the elements, and removing particle coatings exterior to any silicon carbide ( $\mathrm{SiC}$ ) coatings. The two types of particles are then separated by pneumatic classification. The burned-back fertile particles are dissolved and a purified uranyl nitrate solution is obtained by the Acid Thorex solvent extraction process for transfer to refabrication. The burned-back fissile particles require additional crushing and burning to remove the silicon carbide and underlying coatings before dissolution and Purex or Thorex solvent extraction. A simplified reprocessing flow diagram is shown in Fig. 1-3. In addition to the processes shown, this report addresses throughput in the off-gas treatment system where volatile and semivolatile fission products and other contaminants are removed or reduced before process gases are released to the atmosphere. The off-gas sections of this report are interim data and subject to near-term revision. Liquid and solid waste treatment is not addressed in this report. 


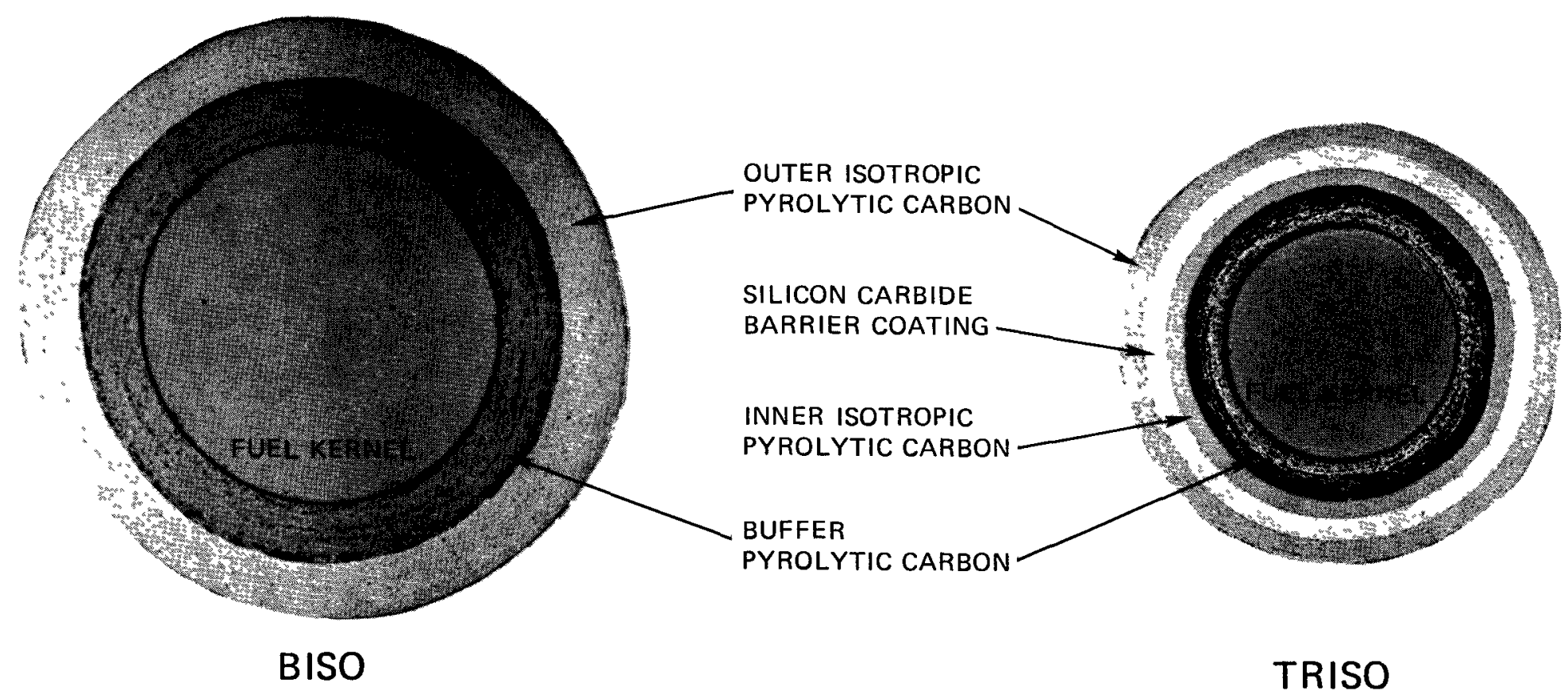

FERTILE

FISSILE

Fig. 1-2. HTGR coated fuel particles 


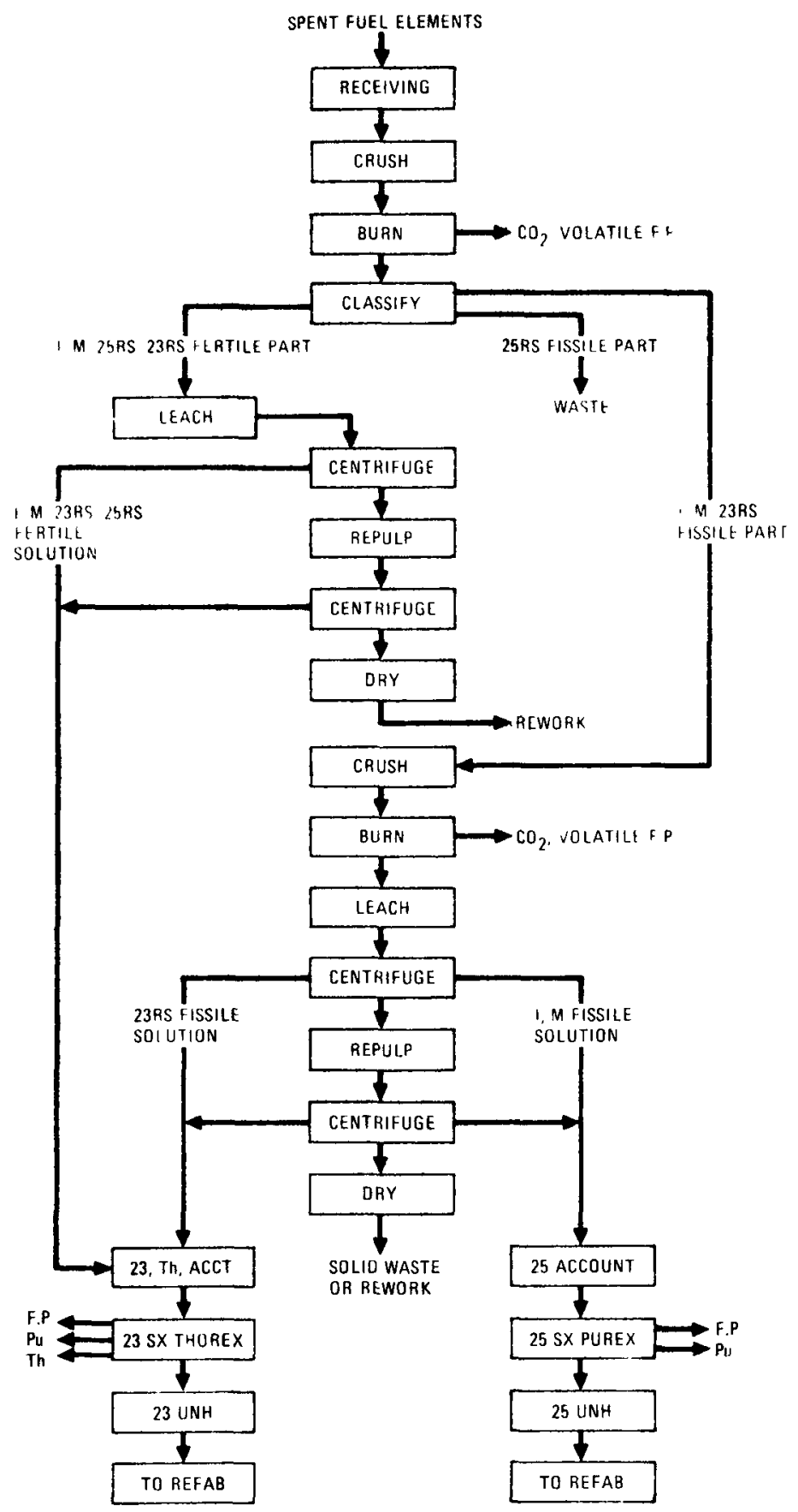

I ELEMENT = FUEL ELEMENT IN REACTOR'S INITIAL FUEL CHARGE

$M$ EIEMENT - REPLACEMENT FUEI ELEMENT CONTAINING 936 ENRICHED URANIUM 23R ELEMENT = REFABRICATED FULL ELEMENT CONTAINING RECOVERED BRED U 233 25R F. _EMENT REFABPICATED FUEL ELEMENT CONTAINING U 235 RECOVERED FROM SPENT I AND M ELEMENTS

Fig. 1-3. HTGR fuel reprocessing flow diagram 
Fort St. Vrain fuel elements will also be processed in the HRDF. Several process modifications are required to handle Fort St. Vrain fuel. Details are shown in flow sheets in Ref. 1-2 but are not specifically addressed in this report.

\section{REFERENCES}

1-1. "National Program Plan for HTGR Fuel Recycle Development," United States Energy Research and Development Administration, October 1976.

1-2. Abraham, L., and N. Holder, "Reprocessing Flowsheet Review and Material Balance," General Atomic Report GA-Al4319, to be published.

1-3. Hamilton, C. J., et a1., "HTGR Spent Fuel Composition and Fuel Element Block Flow," ERDA Report GA-A13886, General Atomic Company, Vol. I, July $1,1976$.

1-4. Holder, N. D., V. H. Pierce, and M. P. Rothstein, "An Economic Analysis of U-235 Recycle in the HTGR," ERDA Report GA-A13836, General Atomic Company, July 15, 1976.

1-5. Rothstein, M. P., "Fuel Cycle Cost Comparison of Choices in U-235 Recycle in the HTGR," ERDA Report GA-A14060, General Atomic Company, July 1976. 


\section{REPROCESSING FEED MATERIAL DEFINITION}

\subsection{FUEL ELEMENT TYPES}

As can be seen from Fig. 1-1, four types of spent fuel elements are expected to be received for reprocessing: those originally loaded with $93 \%$ U-235-enriched uranium at the fresh fuel plant for initial (I) reactor cores and those for fresh makeup (M) reactor reload segments, those containing recycle U-235 (25R), and those containing recycle U-233 (23R). A11 elements are originally loaded with fertile thorium and will contain bred $\mathrm{U}-233$.

The types described above include both standard fuel elements (Fig. 2-1) and elements machined for control rod passage (Fig, 2-2). Not shown are control rod elements from the bottom layer of the reactor core which contain more graphite to close off the control rod channels. Typically, a 3000-MW(t) LHTGR reactor* will include the following in an average segment (one-quarter core) (Ref, 2-1):

$\begin{array}{lr}\text { Standard elements } & 842 \\ \text { Full control rod elements } & 126 \\ \text { Bottom control rod elements } & \frac{18}{986}\end{array}$

The standard and control rod spent fuel elements may contain mixtures of four types of particles: BISO-coated fertile thorium/U-233 particles, TRISO-coated fissile U-235 particles, or TRISO-coated fissile recycle U-233 or TRISO-coated recycle U-235 particles.

*The proposed General Atomic Lead Unit Plant design is not considered in this report. 


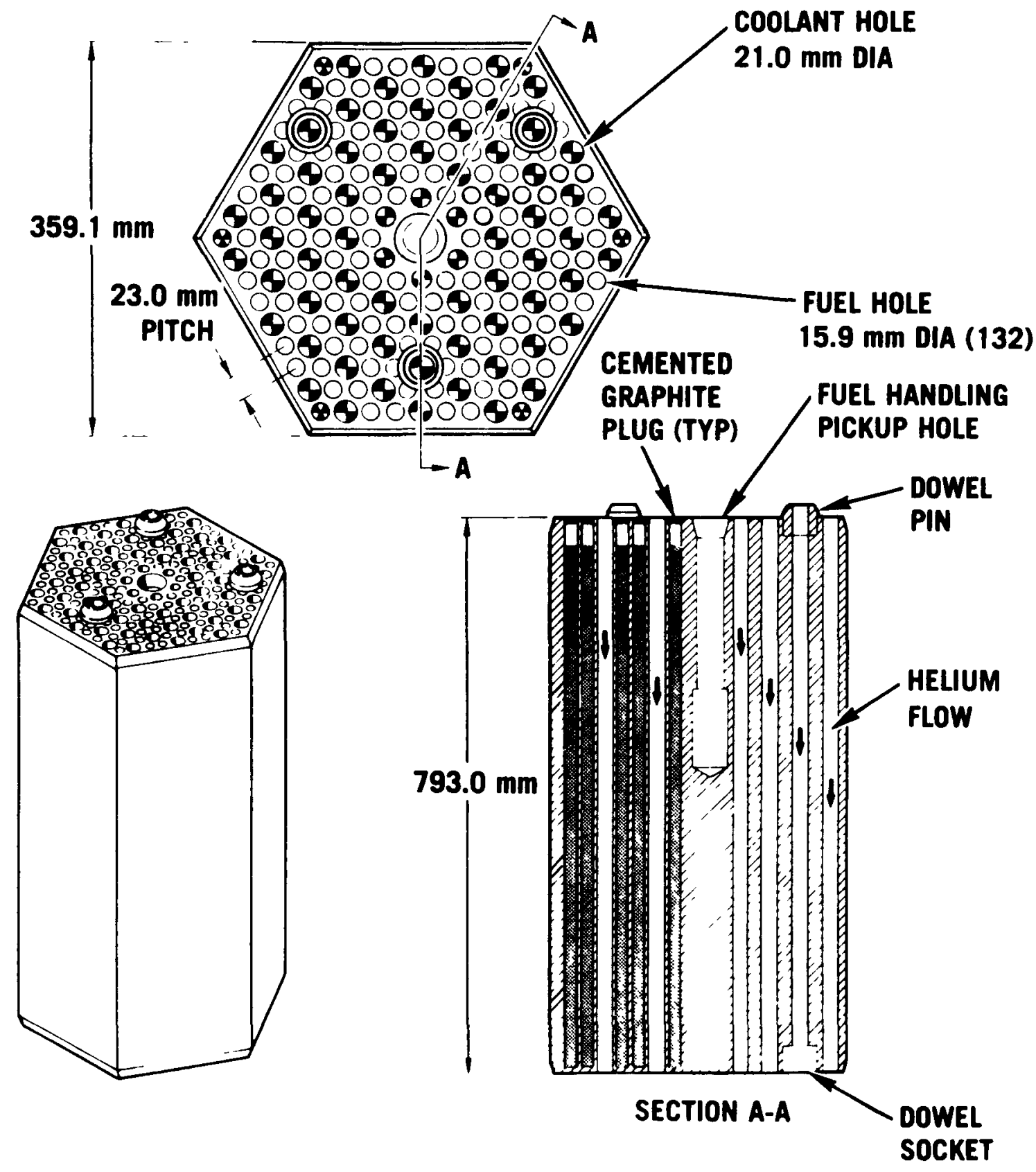

Fig. 2-1. HTGR standard fuel element 

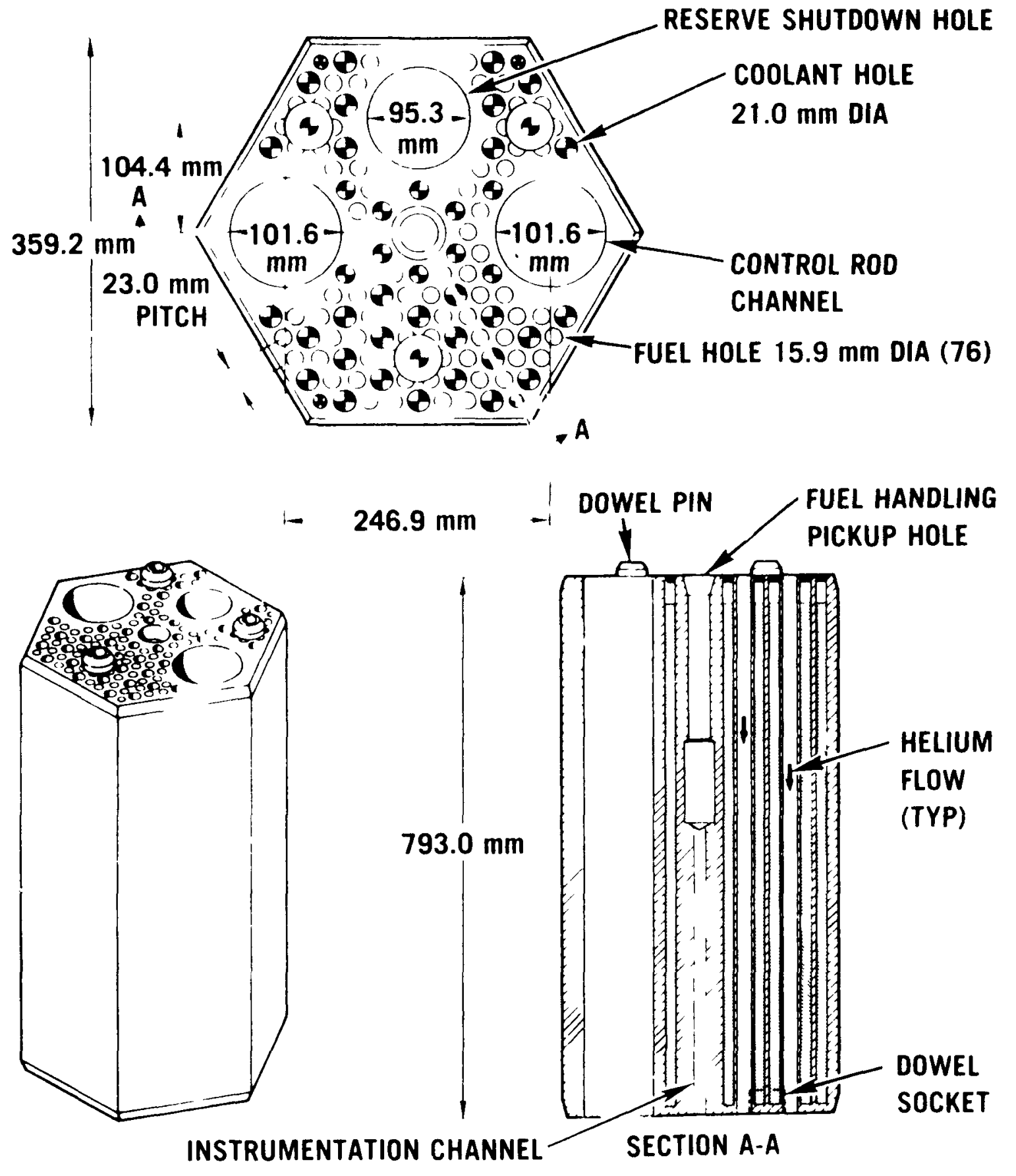

Fig. 2-2. HTGR control fuel element 
In addition to the LHTGR elements described above, Fort St. Vrain (FSV) fuel is expected to be reprocessed in the HRDF. The exterior configuration of the FSV elements can be considered essentially the same as the LHTGR standard and control elements for reprocessing purposes. Particle variations include TRISO coatings on fertile particles and a mixed thorium/uranium fissile particle design in early FSV segments, necessitating adjustments in the processing flow sheets.

A summary of the fuel element types considered for the current flow sheet review is shown in Table 2-1. Additional possible feed materials include German High-Temperature Reactor (HTR) fuels, HTGR reflector blocks, and scrap fuel elements from refabrication. These materials are not considered in this brief review.

\subsection{FUEL ELEMENT COMPOSITION}

In addition to fuel element configuration, fuel element composition is an important reprocessing parameter. Fissile uranium throughput constitutes the valuable inventory of the reprocessing plant, from the standpoint of both economics and regulations concerning safeguarding special nuclear material. Other heavy metals and fission product content affects the throughput of many of the processes, particularly in solvent extraction, and also affects off-gas and waste treatment. Average projected content of several of the fuel element types is shown in Table 2-2.

"As-loaded" or "fresh" fuel content is also shown in Table 2-2 since the plant should be capable of handling unirradiated fuel elements returned either from a reactor or from refabrication scrap recovery. Table 2-2 is only a partial list; initial fuel element loadings will vary from segment to segment for both FSV and LHTGR fuel. Spent fuel composition will vary, depending on reactor loading and operating conditions. Control rod fuel elements are a part of all segments (the two shown at the bottom of the table give only a typical comparison). Special buffer zone elements with specialized fuel loadings are not shown. 
TABLE 2-1

HRDF REPROCESSING FEED MATERIALS

\begin{tabular}{|c|c|c|c|}
\hline $\begin{array}{c}\text { Spent } \\
\text { Fuel Type }\end{array}$ & Fue1 Element & Fissile Particle & $\begin{array}{l}\text { Fertile } \\
\text { Particle }\end{array}$ \\
\hline Fort St. Vrain & $\begin{array}{l}\text { Standard } \\
\text { Full control rod } \\
\text { Bottom control rod }\end{array}$ & $\begin{array}{l}\text { TRISO }(\mathrm{Th}, \mathrm{U}) \mathrm{C}_{2} \\
(\mathrm{Th} / \mathrm{U}-233, \mathrm{U}-235)\end{array}$ & $\begin{array}{l}\text { TRISO ThC } \\
\text { (Th/U-233) }\end{array}$ \\
\hline Fort St. Vrain & $\begin{array}{l}\text { Standard } \\
\text { Fu11 contro1 rod } \\
\text { Bottom control rod }\end{array}$ & $\begin{array}{l}\text { TRISO UC } 2 \\
(\mathrm{U}-235)\end{array}$ & $\begin{array}{l}\text { TRISO ThO2 } \\
(\mathrm{Th} / \mathrm{U}-233)\end{array}$ \\
\hline LHTGR I,M & $\begin{array}{l}\text { Standard } \\
\text { Full control rod } \\
\text { Bottom control rod }\end{array}$ & $\begin{array}{l}\text { TRISO } \mathrm{UC}_{\mathrm{x}} \mathrm{O}_{\mathrm{y}} \\
(\mathrm{U}-235)\end{array}$ & $\begin{array}{l}\text { BISO } \mathrm{ThO}_{2} \\
(\mathrm{Th} / \mathrm{U}-233)\end{array}$ \\
\hline LHTGR 23R & $\begin{array}{l}\text { Standard } \\
\text { Full control rod } \\
\text { Bottom control rod }\end{array}$ & $\begin{array}{l}\text { TRISO } \mathrm{UC}_{\mathrm{x}} \mathrm{O}_{\mathrm{y}} \\
(\mathrm{U}-233)\end{array}$ & $\begin{array}{l}\text { BISO } \mathrm{ThO}_{2} \\
(\mathrm{Th} / \mathrm{U}-233)\end{array}$ \\
\hline LHTGR 25R & $\begin{array}{l}\text { Standard } \\
\text { Full control rod } \\
\text { Bottom control rod }\end{array}$ & $\begin{array}{l}\text { TRISO } \mathrm{UC}_{\mathrm{x}} \mathrm{O}_{\mathrm{y}} \\
(\mathrm{U}-235)\end{array}$ & $\begin{array}{l}\text { BISO } \mathrm{ThO}_{2} \\
(\mathrm{Th} / \mathrm{U}-233)\end{array}$ \\
\hline
\end{tabular}


TABLE 2-2

AVERAGE FUEL ELEMENT DEFINITIONS - HRDF

\begin{tabular}{|c|c|c|c|c|c|c|c|}
\hline \multirow[b]{3}{*}{ Fuel Type } & \multirow[b]{3}{*}{ Fuel Design } & \multicolumn{6}{|c|}{ Average $\mathrm{Kg}$ /Fuel Element (Approximate) } \\
\hline & & \multicolumn{2}{|c|}{$\mathrm{U}$ Content } & \multicolumn{2}{|c|}{ Th Content } & \multirow{2}{*}{$\begin{array}{l}\text { Fission } \\
\text { Products }\end{array}$} & \multirow{2}{*}{$\begin{array}{c}\text { Other } \\
\text { Heavy Metal }\end{array}$} \\
\hline & & Fresh & Spent & Fresh & Spent & & \\
\hline & Average & $6-y \mathbf{B}$ & rnup ( $R$ & f. $2-2)$ & & & \\
\hline \multicolumn{8}{|l|}{ FSV } \\
\hline Segment 4 & Fissile - TRISO $(\mathrm{Th}, \mathrm{U}) \mathrm{C}_{2}$ & 0.62 & 0.23 & & & 0.54 & 0.02 \\
\hline Standard & Fertile - TRISO ThC $_{2}$ & & 0.23 & 7.49 & 6.93 & 0.33 & Trace \\
\hline Average - & Loaded at Reload 9 - Disc & harged & t Reloa & $13-4$ & yr Burr & p (Ref. 2- & \\
\hline \multicolumn{8}{|l|}{ Large HTGR ${ }^{(a)}$} \\
\hline Makeup & Fissile - TRISO UC ${ }_{x}{ }^{0} y$ & 0.83 & 0.22 & & & 0.58 & 0.02 \\
\hline Standard & Fertile - BISO $\mathrm{ThO}_{2}$ & & 0.26 & 8.55 & 7.94 & 0.35 & Trace \\
\hline \multicolumn{8}{|l|}{ Large $H T G R$} \\
\hline $23 R$ & Fissile - TRISO $\mathrm{UC}_{\mathbf{x}}{ }^{0} \mathrm{y}$ & 0.68 & 0.16 & & & 0.50 & Trace \\
\hline Standard & Fert1le - BISO $\mathrm{ThO}_{2}$ & & 0.26 & 8.55 & 7.94 & 0.35 & Trace \\
\hline \multicolumn{8}{|l|}{ Large HTGR } \\
\hline $25 \mathrm{R}$ & Fissile - TRISO UC $\mathrm{x}_{\mathrm{y}}{ }^{\mathrm{y}}$ & 2.10 & 1.40 & & & 0.43 & 0.17 \\
\hline Standard & Fertile - BISO $\mathrm{ThO}_{2}$ & & 0.26 & 8.55 & 7.94 & 0.35 & Trace \\
\hline Average - & Loaded in Initial Core - & Dischar & ed at $R$ & load 1 & $1-y \mathrm{r}$ & nup (Ref. & $2-3)$ \\
\hline \multicolumn{8}{|l|}{ Large HTGR } \\
\hline Initial core & Fissile - TRISO UC ${ }_{x}{ }_{y}$ & 0.45 & 0.26 & & & 0.18 & Trace \\
\hline Standard & Fertile - BISO $\mathrm{ThO}_{2}$ & & 0.14 & 9.50 & 9.32 & 0.04 & Trace \\
\hline Average & - Loaded at Reload 1 - Di & scharge & at $\operatorname{Re} 1$ & ad $5-$ & -yr Bur & p (Ref. 2 & \\
\hline \multicolumn{8}{|l|}{ Large HTGR } \\
\hline Makeup & Fissile - TRISO $U C_{\mathrm{x}}{ }_{\mathrm{y}}$ & 0.74 & 0.18 & & & 0.53 & 0.02 \\
\hline Standard & Fertile - BISO $\mathrm{ThO}_{2}$ & & 0.26 & 8.55 & 7.91 & 0.38 & Trace \\
\hline \multicolumn{8}{|l|}{ Large HTGR } \\
\hline Makeup & Fissile - TRISO UC ${ }_{x}{ }^{0} y$ & 0.42 & 0.10 & & & 0.30 & 0.01 \\
\hline Top control & Fertile - BISO $\mathrm{ThO}_{2}$ & & 0.15 & 4.87 & 4.51 & 0.22 & Trace \\
\hline \multicolumn{8}{|l|}{ Large HTGR } \\
\hline Makeup & Fisstle - TRISO UC $x_{y}^{O}$ & 0.32 & 0.08 & & & 0.23 & Trace \\
\hline $\begin{array}{l}\text { Bottom (b) } \\
\text { control }\end{array}$ & Fertile - BISO $\mathrm{ThO}_{2}$ & & 0.11 & 3.68 & 3.40 & 0.16 & Trace \\
\hline
\end{tabular}

(a) Philadelphia Electric unit type design.

(b) Assumes per-rod loading equivalent to standard element. 
The averaging effect in Table 2-2 must be realized. A number of factors affect fuel loadings, including variations within allowable ranges in the fresh fuel loading specifications and the use of fuel rod blends to achieve desired loadings (typically 17-18 blends in fresh fuel and 15 blends in refabricated fuel). Spent fuel composition will vary according to reactor core position, years of burnup, and individual reactor operating history. The averages shown are derived from FSV as-loaded and projected fuel data, and from LHTGR designs projected for reactors of the Philadelphia Electric unit type. Due to the complexity of variables affecting fuel element loadings and burnup, and to possible fuel design changes pending in General Atomic Lead Unit Plant studies, average fuel element definitions are used for projecting throughput in the system descriptions and material balances.

\subsection{FEED MATERIAL VARIATIONS}

In addition to fuel element composition variations, reprocessing throughput will be affected by many other factors, some under direct control of recycle plant management and others containing elements of uncertainty. As can be seen in Table 2-2, LHTGR initial core standard elements average less uranium and more thorium than the makeup standard elements. This reflects the lower burnup expected for some segments of the core (i.e., approximately one-fourth of the core is replaced after one year of operation, one-fourth after two years, etc.). Only one segment of the initial core receives full burnup while all of the makeup elements are expected to receive full burnup. In addition, refabricated elements will not be returned for processing for four or more years after their manufacture, resulting in only initial and makeup elements being reprocessed for at least the first five years of HRDF operation. Early HRDF throughput is, therefore, market-dependent. It may be further complicated by reactors in startup mode experiencing longer-than-expected operating cycles between refueling, again making predictions difficult. Still another set of currently uncertain variables is introduced by the National Thorium Utilization Program (Ref. 2-4) planned HRDF startup date with reference to a projected market, as shown in Fig. 2-3. Discharged fuel elements are projected to exceed processing capacity, particularly in the early years. The recycle management then has 


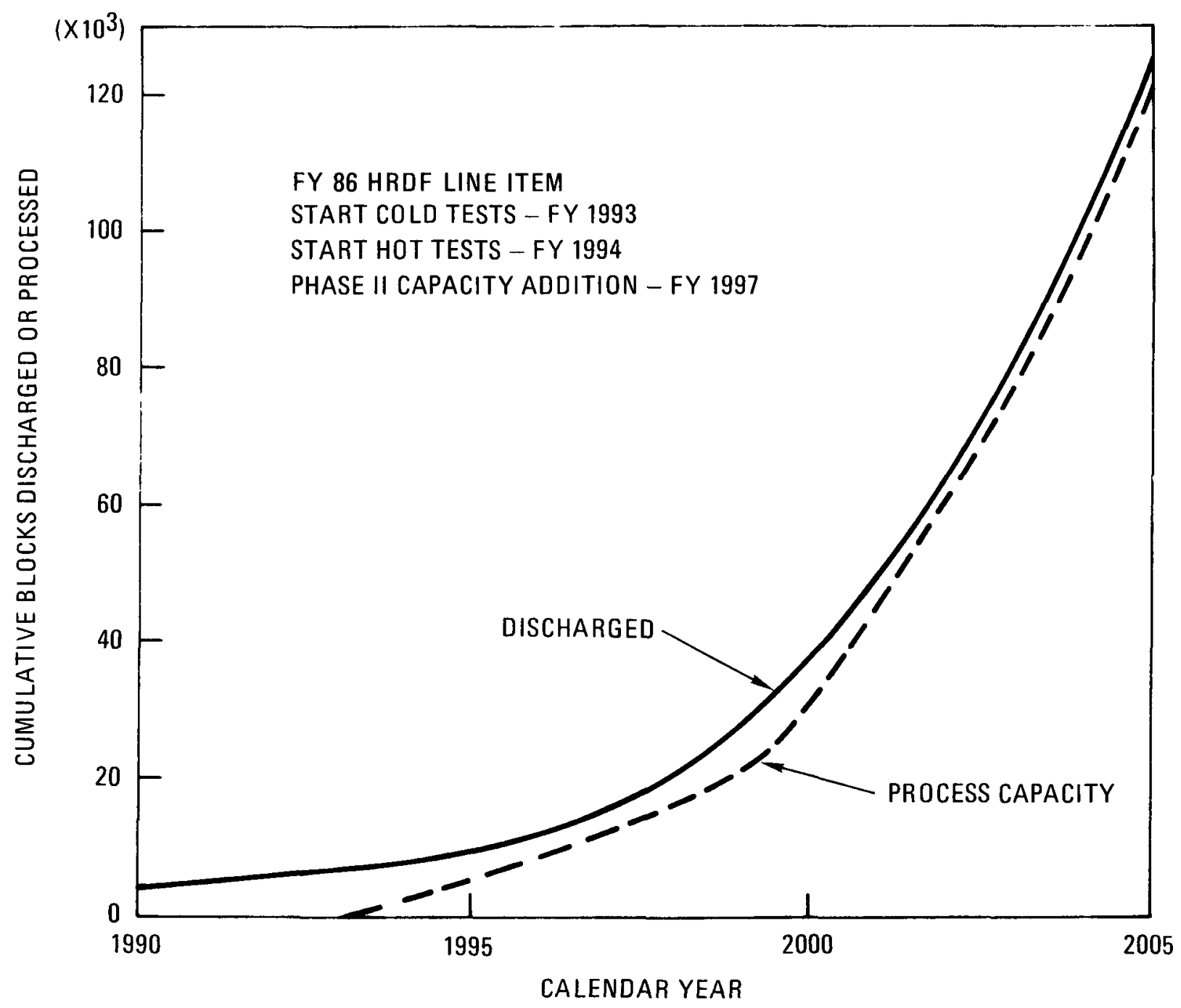

Fig. 2-3. HRDF block flow comparisons (steam-cycle HTGR) (from Ref 2-4) 
a store of elements to choose from and this choice itself affects the subsequent years' throughput. For example, a one-year delay in processing a reactor's fuel would produce an effect approximately as shown in Table 2-3. This effect, multiplied over several reactors or extended to later reloads, could significantly affect HRDF throughput composition. Choices open to recycle management in selecting elements are many. Examples include: processing on a last in-first out (LIFO) basis (processing the newest, hottest elements to gain experience on high burnup fuel), or processing on a first in-first out (FIFO) basis (cooling the fuel as long as possible). Other factors include a large backlog of FSV fuel, possible individual customer contract variations, possible processing of pebble-bed fuel from Germany, and the need to schedule fuel so that solvent extraction lines are continuously fed.

The effects of early-year variations will eventually smooth out (assuming that the same reactors are kept as customers), and the reprocessing plant throughput can be expected to stabilize after about 20 years of operation at about $54 \%$ makeup (M) elements, $44 \% \mathrm{U}-233$ recycle (23R) elements, and $2 \% \mathrm{U}-235$ recycle (25R) elements. These estimates cannot be used as an equipment design basis. The 23R throughput is probably a maximum, but as can be seen in Table 2-4, refabricated 25R elements number about 2,000 at an approximately 20,000-fuel-element reprocessing capacity (1997 forecast) and would represent $10 \%$ of the plant throughput when returned for processing five years later. The basis for this shift can be seen in Table 2-3 because the reactor segment composition varies over time. The reprocessing plant unit operation design capacities, where applicable, must consider both early and late plant throughput to determine the maximum for certain types of fuel elements.

\subsection{YIELDS AND MATERIAL BALANCE BASIS}

Based on the many variables discussed above, coupled with pending Lead Unit Plant design changes that could significantly modify the data in this report, only the equilibrium fuel element throughput after several years of HRDF operation and only average fuel element compositions are considered for the yields and material balance data. 
TABLE 2-3

TYPICAL MIX OF SPENT FUEL ELEMENTS DISCHARGED

FROM AN 1160-MW(e) $\operatorname{HTGR}(a)$

\begin{tabular}{c|r|r|r|r|r|r}
\hline \multirow{2}{*}{ Segment } & \multicolumn{3}{|c|}{ With Recycle } & \multicolumn{3}{c}{ With Recycle } \\
at Reload 2 & \multicolumn{2}{|c|}{ at Reload 3 } \\
\cline { 2 - 7 } 1 & 1064 & & & IM & $23 \mathrm{R}$ & $25 \mathrm{R}$ \\
\hline 2 & 960 & & & 1064 & & \\
3 & 960 & & & 960 & & \\
4 & 960 & & & 960 & & \\
5 & 1064 & & & 960 & & \\
6 & 451 & 278 & 230 & 960 & & \\
7 & 527 & 346 & 86 & 19 & 624 & 317 \\
8 & 497 & 431 & 32 & 602 & 326 & 32 \\
9 & 578 & 457 & 29 & 617 & 418 & 29 \\
10 & 499 & 431 & 29 & 499 & 431 & 29 \\
\hline
\end{tabular}

(a) Illustrative data only. Philadelphia Electric unit type design. 
TABLE $2-4$
HTGR FUEL ELEMENT BLOCK FLOW FOR RECYCLE

\begin{tabular}{|c|c|c|c|c|c|c|c|c|c|}
\hline \multirow[b]{2}{*}{ Year } & \multicolumn{2}{|c|}{ LHTGRs Discharging } & \multicolumn{4}{|c|}{$\begin{array}{l}\text { Fuel Elements Available } \\
\text { for Reprocessing }\end{array}$} & \multicolumn{3}{|c|}{$\begin{array}{l}\text { Fuel Elements Available } \\
\text { from Refabrication }\end{array}$} \\
\hline & $1160 \mathrm{MW}(\mathrm{e})$ & $1550 \mathrm{MW}(\mathrm{e})$ & IS/MS & 23RS & 25RS & Total & $23 R$ & $25 R$ & Total \\
\hline 1989 & 1 & & 1,064 & & & 1,064 & 309 & 255 & 564 \\
\hline 1990 & 1 & & 960 & & & 960 & 346 & 86 & 432 \\
\hline 1991 & 1 & 1 & 2,336 & & & 2,336 & 793 & 359 & 1,152 \\
\hline 1992 & 1 & 3 & 5,088 & & & 5,088 & 1,706 & 813 & 2,519 \\
\hline 1993 & 1 & 5 & 7,944 & & & 7,944 & 2,831 & 981 & 3,812 \\
\hline 1994 & 1 & 7 & 9,908 & 309 & 255 & 10,472 & 3,888 & 1,057 & 4,945 \\
\hline 1995 & 1 & 9 & 12,672 & 346 & 86 & 13,104 & 5,047 & 1,136 & 6,183 \\
\hline 1996 & 1 & 12 & 16,080 & 793 & 359 & 17,232 & 6,684 & 1,549 & 8,233 \\
\hline 1997 & 1 & 16 & 20,321 & 1,706 & 813 & 22,840 & 8,864 & 2,088 & 10,952 \\
\hline 1998 & 1 & 20 & 24,308 & 2,831 & 981 & 28,120 & 11,060 & 2,330 & 13,390 \\
\hline 1999 & 1 & 24 & 28,439 & 3,888 & 1,057 & 33,384 & 13,348 & 2,485 & 15,833 \\
\hline 2000 & 1 & 28 & 32,705 & 5,047 & 1,136 & 38,888 & 15,747 & 2,647 & 18,394 \\
\hline
\end{tabular}

(a) Based on the HTGR discharged fuel element forecast for planning purposes made by ERDA, Division of Nuclear Fuel Cycle and Production, in January 1976 (Ref. 2-3).

(b) Illustrative data only; forecast superseded by Ref. 2-4. 
Since several processing unit operations in the head-end also depend on carbon content and particle dimensions and volumes, more detailed average fuel element definitions have been developed for LHTGR standard makeup (M) fuel elements (Table 2-5) and bred U-233 recycle (23\%) standard fuel elements (Table 2-6), using the midpoint of the kernel size, coating thickness, and density ranges given in the HTGR Fuel Product Specification (Ref. 2-5). Fresh and spent fuel composition and radioactivity have been derived from Ref. 2-3: as-loaded for Reload 9 and as-discharged for Reload 13 with 180day cooling. Decay heat data is taken from Ref. 2-6. Some uncertainty exists in the oxygen/carbon content definition of the fissile kernel. However, none of the processes are very sensitive to this number at this level of calculation and the exact ratio has not been pursued in depth. Matrix and shim particle details are not included for the same reasons. U-235 recycle particles are currently not specified; however, a definition based on a specification similar to that for bred U-233 recycle particles (Ref. 2-6) is given in Table 2-7.

Table 2-8 summarizes the range of variables for fissile and fertile particles assumed in deriving the average fuel element definitions (Ref. 2-5). Table 2-9 summarizes the major fission products, heavy metals, and other contaminants assumed in the LHTGR fuel elements after 180 days cooling time (Ref. 2-3). Process paths (separation from precursors) and decay time during processing will have a significant bearing on quantities present in any given process step; however, these factors have not been considered in this study.

\section{REFERENCES}

2-1. Turner, R. F., "Fuel Criteria for GA/FFF Plant Design," General Atomic Company, unpublished data, October 3, 1975.

2-2. Union Carbide Corporation (UCC-ND), et al., "Criteria Document for HTGR Fuel Recycle Hot Engineering Test," Volume III, October 1976.

2-3. Hamilton, C. J., et al., "HTGR Spent Fuel Composition and Fue1 Element Block Flow," Volumes I and II, General Atomic Report GA-A13886, July 1976. 
2-4. "National Program Plan for HTGR Fuel Recycle Development," United States Energy Research and Development Administration, October 1976.

2-5. McEachern, D., et a1., "HTGR Fuel Product Specification," ERDA Report GA-A13464, General Atomic Company, Issue B, January 1976.

2-6. Sund, R. E., D. E. Strong, and B. A. Engholm, "HTGR Spent Fuel Element Decay Heat and Source Term Analysis," ERDA Report GA-A14140, General Atomic Company, February 1977. 
TABLE 2-5

SPENT FUEL ELEMENT DEFINITION - (TBV)

(Average LHTGR Standard Makeup Element;

TRISO UC $\mathrm{x}_{\mathbf{y}}$ Fissile; BISO $\mathrm{ThO}_{2}$ Fertile)

Fuel Element Composition

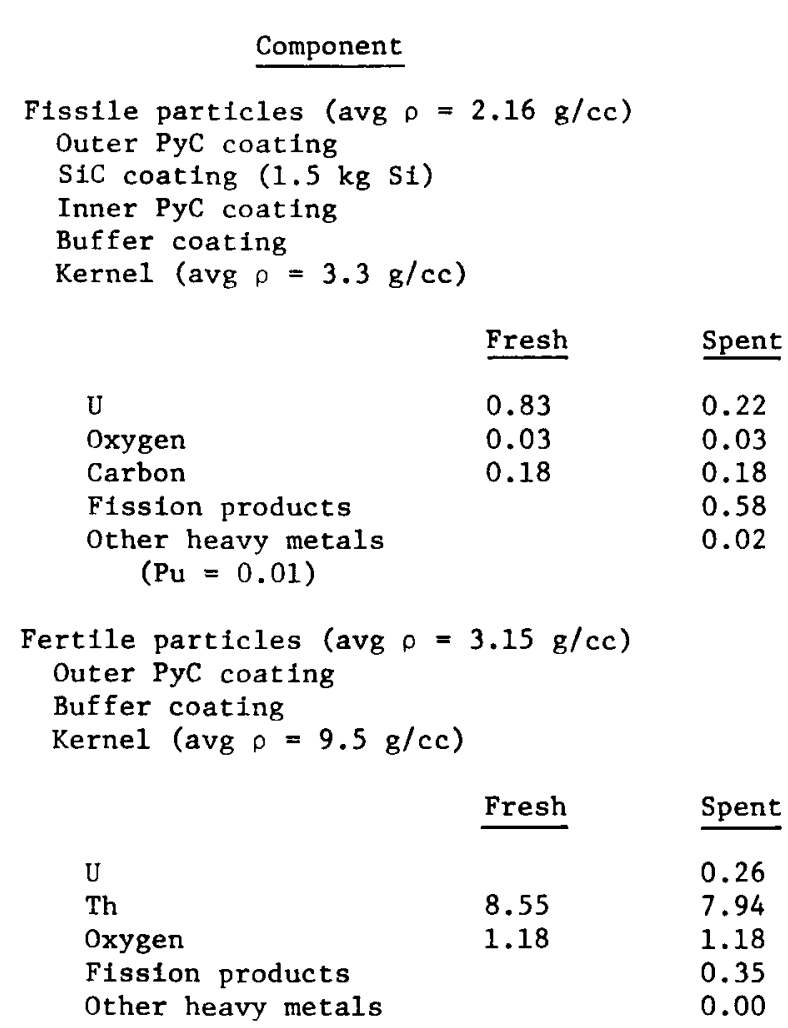

Carbon (includes graphite fuel element, plugs,

Weight

(kg/FE)

1.80

2.10

0.95

0.57

1.03

6.45

dowels, fuel rod matrix, shim)

Boron

4.38

1.75

9.73

pent

.94

35

0.00

Radioactivity (TBV)

$\mathrm{Ci} / \mathrm{FE}$

180 Days After Discharge

Fissile fraction

Fertile fraction

Total

Decay Heat

Fissile fraction

Fertile fraction
35,690

48,930

84,620

W/FE

180 Days Decay

156

183 
TABLE 2-6

SPENT FUEL ELEMENT DEFINITION - (TBV)

(Average LHTGR U-233 Recycle Element;

TRISO UC $\mathrm{x}_{\mathrm{y}}$ Fissile; BISO $\mathrm{ThO}_{2}$ Fertile)

Fuel Element Composition

Weight

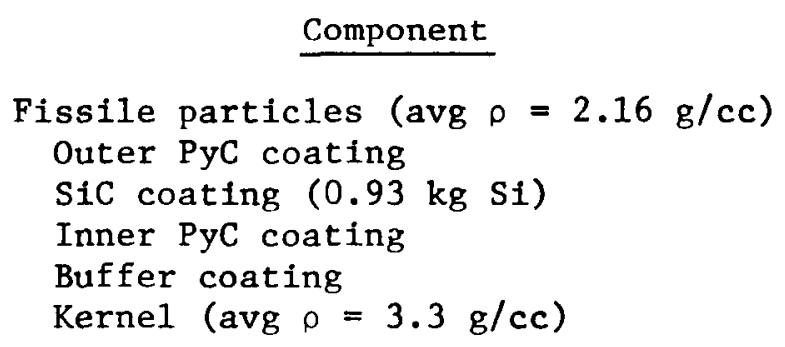

Fresh

Spent

$\begin{array}{lll}\text { U } & 0.68 & 0.16 \\ \text { Oxygen } & 0.03 & 0.03 \\ \text { Carbon } & 0.17 & 0.17 \\ \text { Fission products } & & 0.50 \\ \text { Other heavy metals } & & -\end{array}$$$
(\mathrm{Pu}=0.001)
$$

$(\mathrm{kg} / \mathrm{FE})$

1.09

1.32

0.61

0.42

0.86

Fertile particles (avg $\rho=3.15 \mathrm{~g} / \mathrm{cc}$ )

Outer PyC coating

Buffer coating

Kerne1 (avg $\rho=9.5 \mathrm{~g} / \mathrm{cc}$ )

$\begin{array}{lll} & \text { Fresh } & \text { Spent } \\ \mathrm{U} & & 0.26 \\ \text { Th } & 8.55 & 7.94 \\ \text { Oxygen } & 1.18 & 1.18 \\ \text { Fission products } & & 0.35 \\ \text { Other heavy metals } & & --\end{array}$

Carbon (includes graphite fuel element, plugs,

dowels, matrix, shim)

4.38

1.75

9.73

15.86

Boron 
TABLE 2-6 (Continued)

Radioactivity (TBV)

Fertile fraction

Tota1

$\mathrm{C} i / \mathrm{FE}$

180 Days After Discharge

30,945

48,929

79,874

Decay Heat

\begin{tabular}{c} 
W/FE \\
180 Days Decay \\
\hline
\end{tabular}

Fissile fraction

130

Fertile fraction

183 
TABLE 2-7

SPENT FUEL ELEMENT DEFINITION - TBV

(Average LHTGR U-235 Recycle Element;

TRISO UC $\mathrm{x}_{\mathrm{y}} \mathrm{O}$ Fissile; BISO $\mathrm{ThO}_{2}$ Fertile)

Fue1 Element Composition

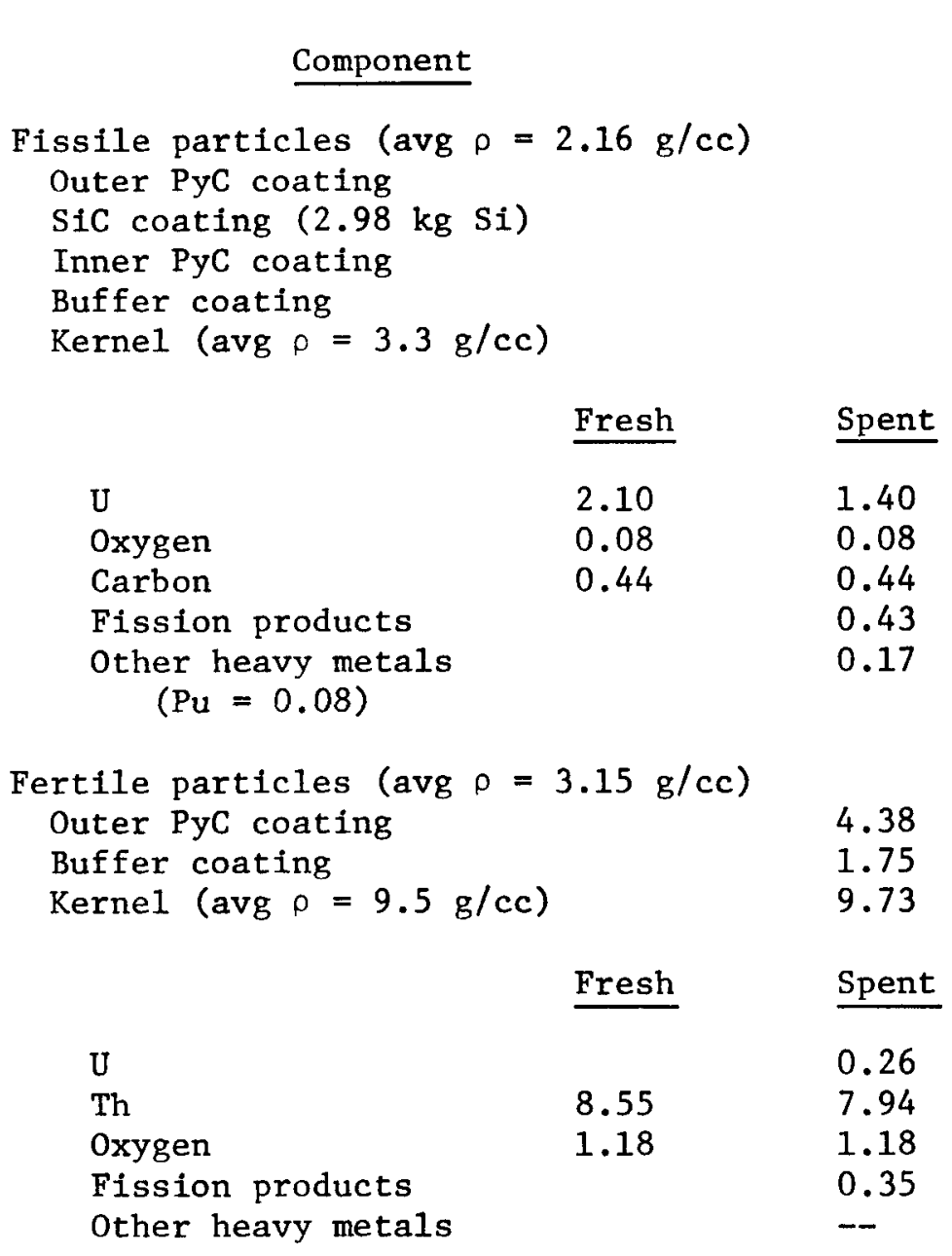

Weight

$(\mathrm{kg} / \mathrm{FE})$

issile particles (avg $\rho=2.16 \mathrm{~g} / \mathrm{cc}$ )

13.04

3.35

4.03

1.87

1.27

2.52

15.86

Carbon (includes graphite fuel element, plugs, dowels, matrix, shim)

Boron

0.01

Total Weight

121.28 
TABLE 2-7 (Continued)

Radioactivity (TBV)

\section{$\mathrm{Ci} / \mathrm{FE}$ \\ 180 Days After Discharge}

Fissile fraction

Fertile fraction

28,040

48,929

Tota1

76,969

Decay Heat

$\mathrm{W} / \mathrm{FE}$

180 Days Decay

Fissile fraction

150

Fertile fraction

183 
TABLE 2-8

RANGE OF AVERAGE VALUES FOR UC ${ }_{x} 0_{y}$ FISSILE

AND $\mathrm{ThO}_{2}$ FERTILE PARTICLES FOR LHTGR(a)

\begin{tabular}{|c|c|c|c|}
\hline & Makeup $^{(b)}$ & $23 R^{(b)}$ & $25 R^{(c)}$ \\
\hline \multicolumn{4}{|l|}{ Fissile Particle } \\
\hline Uranium ( $\mu \mathrm{g}$ U/kernel) & $40 \pm 10$ & $65 \pm 10$ & $65 \pm 10$ \\
\hline Kernel density $\left(\mathrm{g} / \mathrm{cm}^{3}\right)$ & $\geq 3.0 \geq 3.6$ & $\geq 3.0 \geq 3.6$ & $3.0-3.6$ \\
\hline Kernel size range $(\mu \mathrm{m})$ & $285-325$ & $340-380$ & $340-380$ \\
\hline $\begin{array}{l}\text { Buffer thickness }(\mu \mathrm{m}) \\
\text { Buffer density }\left(\mathrm{g} / \mathrm{cm}^{3}\right)\end{array}$ & $\begin{array}{l}45-75 \\
0.90-1.20\end{array}$ & $\begin{array}{l}50-80 \\
0.90-1.20\end{array}$ & $\begin{array}{l}50-80 \\
0.90-1.20\end{array}$ \\
\hline $\begin{array}{l}\text { Inner isotropic thickness }(\mu \mathrm{m}) \\
\text { Inner isotropic density }\left(\mathrm{g} / \mathrm{cm}^{3}\right)\end{array}$ & $\begin{array}{l}25-45 \\
1.85-1.95\end{array}$ & $\begin{array}{l}25-45 \\
1.85-1.95\end{array}$ & $\begin{array}{l}25-45 \\
1.85-1.95\end{array}$ \\
\hline $\begin{array}{l}\text { Silicon carbide thickness }(\mu \mathrm{m}) \\
\text { Silicon carbide density }\left(\mathrm{g} / \mathrm{cm}^{3}\right)\end{array}$ & $\begin{array}{l}30-40 \\
\geq 3.18\end{array}$ & $\begin{array}{l}30-40 \\
\geq 3.18\end{array}$ & $\begin{array}{l}30-40 \\
\geq 3.18\end{array}$ \\
\hline $\begin{array}{l}\text { Outer isotropic thickness }(\mu \mathrm{m}) \\
\text { Outer isotropic density }\left(\mathrm{g} / \mathrm{cm}^{3}\right)\end{array}$ & $\begin{array}{l}30-50 \\
1.75-1.90\end{array}$ & $\begin{array}{l}30-50 \\
1.75-1.90\end{array}$ & $\begin{array}{l}30-50 \\
1.75-1.90\end{array}$ \\
\hline \multicolumn{4}{|l|}{ Fertile Particle } \\
\hline $\begin{array}{l}\text { Kernel density }\left(\mathrm{g} / \mathrm{cm}^{3}\right) \\
\text { Kernel size range }(\mu \mathrm{m})\end{array}$ & $\begin{array}{l}\geq 9.50 \\
400-600\end{array}$ & $\begin{array}{l}\geq 9.50 \\
400-600\end{array}$ & $\begin{array}{l}\geq 9.50 \\
400-600\end{array}$ \\
\hline $\begin{array}{l}\text { Buffer thickness }(\mu \mathrm{m}) \\
\text { Buffer density }\left(\mathrm{g} / \mathrm{cm}^{3}\right)\end{array}$ & $\begin{array}{l}80-110 \\
0.90-1.20\end{array}$ & $\begin{array}{l}80-110 \\
0.90-1.20\end{array}$ & $\begin{array}{l}80-110 \\
0.90-1.20\end{array}$ \\
\hline $\begin{array}{l}\text { Outer isotropic thickness }(\mu \mathrm{m}) \\
\text { Outer isotropic density }\left(\mathrm{g} / \mathrm{cm}^{3}\right)\end{array}$ & $\begin{array}{l}70-90 \\
1.80-1.95\end{array}$ & $\begin{array}{l}70-90 \\
1.80-1.95\end{array}$ & $\begin{array}{l}70-90 \\
1.80-1.95\end{array}$ \\
\hline
\end{tabular}
(a) Philadelphia Electric unit type design.
(b) Reference 2-5.
(c) $25 \mathrm{R}$ particle assumed to be identical to $23 \mathrm{R}$. 
TABLE 2-9

MAJOR FISSION PRODUCTS, HEAVY METALS, AND OTHER CONTAMINANTS IN PROJECTED HRDF THROUGHPUT (PER FUEL ELEMENT) (a)

\begin{tabular}{|c|c|c|c|c|c|c|c|c|c|c|c|}
\hline \multirow[b]{2}{*}{ Element } & \multirow{2}{*}{$\begin{array}{c}\text { Major } \\
\text { Contributing } \\
\text { Isotopes (b) }\end{array}$} & \multirow[b]{2}{*}{$\mathrm{T} 1 / 2^{(\mathrm{c})}$} & \multicolumn{3}{|c|}{ Standard Makeup Element } & \multicolumn{3}{|c|}{ Standard $23 R$ Element } & \multicolumn{3}{|c|}{ Standard 25R Element } \\
\hline & & & 8 & $\mathrm{C}_{1}$ & $w$ & 8 & $C_{1}$ & w & $\mathrm{g}$ & C1 & w \\
\hline Tritium & & $12 Y$ & $4(-3)^{(d)}$ & 77 & $1(-3)$ & $4(-3)$ & 77 & $1(-3)$ & $4(-3)$ & 82 & $1(-3)$ \\
\hline Boron & & & 12 & -- & -- & 12 & -- & -- & 12 & -- & -- \\
\hline Carbon & $c-14$ & $6(3) Y$ & $1(5)$ & $3(-2)$ & $9(-6)$ & $1(5)$ & $3(-2)$ & $9(-6)$ & $1(5)$ & $3(-2)$ & $9(-6)$ \\
\hline Sulfur & $s-35$ & $87 \mathrm{D}$ & 21 & $9(-1)$ & $3(-4)$ & 21 & $9(-1)$ & $3(-4)$ & 21 & $9(-1)$ & $3(-4)$ \\
\hline Chlorine & $c 1-36$ & $3(5) Y$ & $3(-1)$ & $1(-3)$ & $2(-6)$ & $3(-1)$ & $1(-3)$ & $2(-6)$ & $3(-1)$ & $1(-3)$ & $2(-6)$ \\
\hline Krypton & $\mathrm{Kr}-85$ & $11 Y$ & 19 & $6(2)$ & $9(-1)$ & 22 & $7(2)$ & $10(-1)$ & 16 & $5(2)$ & $8(-1)$ \\
\hline Strontium & Sr $-89,90$ & $50 \mathrm{D}, 28 \mathrm{Y}$ & 37 & $6(3)$ & 13 & 40 & $6(3)$ & 13 & 32 & $5(3)$ & 12 \\
\hline Yttrium & $Y-91$ & $59 \mathrm{D}$ & 18 & $4(3)$ & 20 & 19 & $4(3)$ & 20 & 15 & $4(3)$ & 18 \\
\hline Zircontum & $2 r-95$ & $65 \mathrm{D}$ & 105 & $4(3)$ & 23 & 99 & $4(3)$ & 23 & 87 & $4(3)$ & 21 \\
\hline N1obium & $\mathrm{Nb}-95$ & $90 \mathrm{H}, 35 \mathrm{D}$ & $5(-1)$ & $14(3)$ & 51 & $5(-1)$ & $14(3)$ & 51 & $8(-1)$ & $13(3)$ & 47 \\
\hline Ruthenium & Ru-103,106 & $40 \mathrm{D}, 1 \mathrm{Y}$ & 43 & $2(3)$ & 2 & 30 & $1(3)$ & 1 & 34 & $1(3)$ & 1 \\
\hline Rhodium & $\mathrm{Rh}-103,106$ & $57 \mathrm{M}, 30 \mathrm{~S}$ & 4 & $2(3)$ & 11 & 3 & $1(3)$ & 9 & 4 & $1(3)$ & 10 \\
\hline Tin & $S n-123$ & $40 \mathrm{M}$ & $1(-1)$ & 26 & $7(-2)$ & $1(-1)$ & 29 & $8(-2)$ & $1(-1)$ & 25 & $7(-2)$ \\
\hline Antımony & $\mathrm{Sb}-125$ & $3 Y$ & $4(-1)$ & $2(2)$ & $7(-1)$ & $6(-1)$ & $3(2)$ & 1 & $4(-1)$ & $2(2)$ & $6(-1)$ \\
\hline Tellurium & $\begin{array}{l}\mathrm{T} e-125,127 \\
129\end{array}$ & $\begin{array}{l}58 \mathrm{D}, 105 \mathrm{D} \\
9 \mathrm{H}, 33 \mathrm{D}, \\
67 \mathrm{M}\end{array}$ & 12 & $8(2)$ & 1 & 16 & $1(3)$ & 1 & 11 & $8(2)$ & 1 \\
\hline Iodine & $L-129,131$ & $2(7) \times, 8 D$ & 7 & $4(-3)$ & $11(-6)$ & 10 & $4(-3)$ & $12(-6)$ & 6 & $4(-3)$ & $11(-6)$ \\
\hline Xenon & $x e-131,133$ & $12 \mathrm{D}, 5 \mathrm{D}$ & 138 & $8(-3)$ & $8(-6)$ & 122 & $8(-3)$ & $8(-6)$ & 116 & $8(-3)$ & $7(-6)$ \\
\hline Cesium & Cs-134,137 & $21 \mathrm{Y}, 30 \mathrm{Y}$ & 71 & $8(3)$ & 51 & 65 & $7(3)$ & 44 & 60 & $6(3)$ & 42 \\
\hline Barium & $\mathrm{Ba}-137$ & $3 \mathrm{M}$ & 39 & $3(3)$ & 12 & 33 & $3(3)$ & 11 & 32 & $2(3)$ & 10 \\
\hline Cerium & $\mathrm{Ce}-141$ & $32 \mathrm{D}$ & 78 & $17(3)$ & 12 & 74 & $15(3)$ & 11 & 66 & $15(3)$ & 10 \\
\hline Praseodymium & $\operatorname{Pr}-144$ & $17 \mathrm{M}$ & 34 & $17(3)$ & $1(2)$ & 34 & $15(3)$ & $1(2)$ & 30 & $15(3)$ & $1(2)$ \\
\hline Promethium & $\mathrm{Pm}-143$ & $2 \mathrm{Y}$ & 2 & $2(3)$ & 1 & 2 & $2(3)$ & 1 & 2 & $2(3)$ & 1 \\
\hline Europium & Eu-154,155 & $16 \mathrm{Y}, 2 \mathrm{Y}$ & 2 & $2(2)$ & $7(-1)$ & 2 & $1(2)$ & $5(-1)$ & 2 & 80 & $6(-1)$ \\
\hline Radon & $R n-220$ & $56 \mathrm{~s}$ & $1(-9)$ & 1 & $4(-2)$ & $1(-9)$ & 1 & $1(-1)$ & $1(-9)$ & 1 & $4(-2)$ \\
\hline Thor 1um & Th-228 & $2 \mathrm{Y}$ & $8(3)$ & 1 & $4(-2)$ & $8(3)$ & 5 & $4(-2)$ & $8(3)$ & 1 & $4(-2)$ \\
\hline Protoactinlum & $\mathrm{Pa}-233$ & $27 \mathrm{D}$ & $3(-1)$ & $4(3)$ & 10 & $3(-1)$ & $4(3)$ & 10 & $3(-1)$ & $4(3)$ & 10 \\
\hline Uranium & $\mathrm{U}-232,233$ & $74 \mathrm{Y}, 2(5) \mathrm{Y}$ & $5(2)$ & 5 & $2(-1)$ & $4(2)$ & 7 & $2(-1)$ & $17(2)$ & 5 & $2(-1)$ \\
\hline Plutonium & $\begin{array}{l}\text { Pu-238, 239, } \\
241\end{array}$ & $\begin{array}{l}89 \mathrm{Y}, 2(4) \mathrm{Y}, \\
13 \mathrm{Y}\end{array}$ & 10 & $2(2)$ & 4 & 1 & 18 & $5(-1)$ & 81 & $14(2)$ & 30 \\
\hline
\end{tabular}

(a) From Refs. 2-3 and 2-6. LHTGR standard makeup spent fuel element discharged at Reload 13, 180-day cooled.

(b) Isotopes contributing to majority of radioactivity and decay heat.

(c) Half life of major contributing isotopes. 


\section{PROCESS YIELDS AND MATERIAL THROUGHPUT}

Yields and throughput discussed in this section are based on average fuel element definitions in a recycle plant operating at equilibrium (several years after startup).

\subsection{REPROCESSING FLOW DIAGRAM AND MATERIAL BALANCE DESCRIPTION}

Figure 3-1 summarizes the current proposed HRDF reprocessing flow sheet. Detailed flow sheets, process descriptions, and development recommendations are included in General Atomic Report GA-A14319 (Ref. 3-1). The detailed flow sheets also include the processing of Fort St. Vrain (FSV) fuel, which requires special handling because of its TRISO-coated fertile particles and variations in early segment fissile particle design.

As discussed in Section 2.3, approximately half of the reprocessing plant annual throughput at equilibrium will consist of LHTGR makeup fuel elements (spent fuel elements originally loaded with 93\% U-235-enriched uranium at a fresh fuel plant as reactor segment makeup). The detailed average daily material balance for the plant, therefore, is based on 43 fuel elements per day (HRDF Phase I capacity), all makeup standard fuel elements. For most operations, this balance is, on the average, overstated by the control rod element throughput (about 15\% of the total throughput). However, without the definition of strict material controls, there is no assurance that each batch processed will contain an exact percentage of control rod elements and their effect has been neglected for this review. Since fuel design changes are pending in Lead Unit Plant studies, a complete material balance has not been developed for other types of fuel ele-

ments to be processed in the plant (FSV, 23R, and 25R), nor has a "combined" material balance been projected. (If parallel unit operations are installed in HRDF, it is likely that two different types of fuel elements could be 
SPENT FUEL ELEMENTS

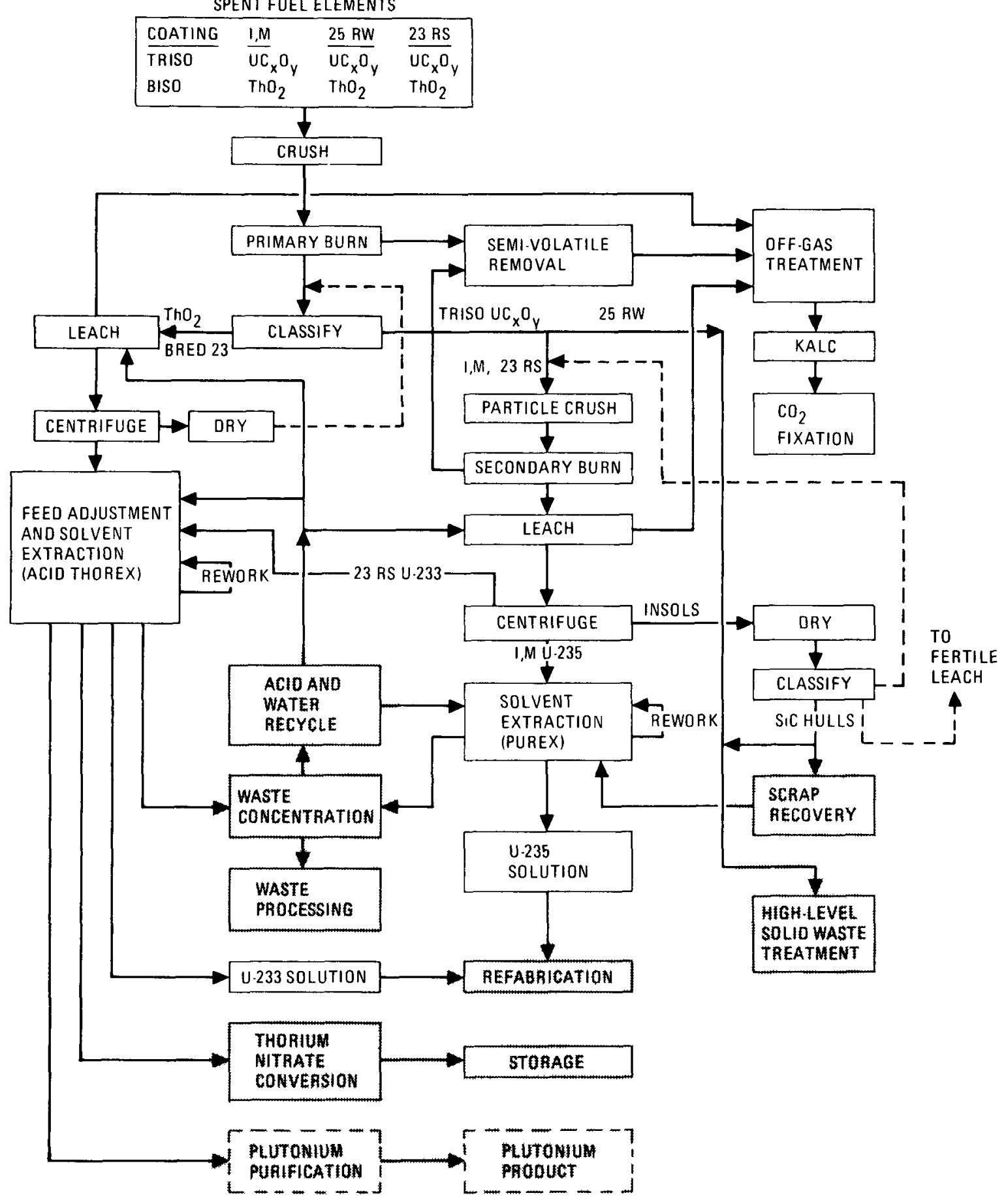

NOT ADORESSED IN THIS REFORT

Fig. 3-1. Reprocessing flow diagram 
processed simultaneously in separate burners. For example, both would be contributing at the same time to burner off-gas treatment. A planned future study including computer simulation of HRDF reprocessing operations should better define the possibilities and effects of such simultaneous processing.)

3.2. UNIT OPERATION YIELDS AND THROUGHPUT - HEAD-END

Head-end unit operations are defined as those preparing the fuel material for solvent extraction; i.e., fuel element and particle crushing and burning, particle classification, particle dissolution, and insols (insolubles) drying.

Yields and material throughput from head-end unit operations are of interest from several standpoints including:

1. Feed and product specifications - Many process steps require specific characteristics in feed material; therefore, the feed material specification becomes the product specification for the preceding step. (For example, the primary burner feed specification becomes the fuel element crusher product specification.)

2. Waste stream composition - The nuclide content, activity, and decay heat composition of waste streams define waste treatment required to minimize the environmental effect of fuel reprocessing.

3. Special nuclear material inventory - Safeguards requirements for special nuclear material will require strict accounting of locations of nonrecoverable material, as well as incoming and outgoing inventory. In addition, customer account settlements will be based on identification of recovered fissile isotopes in each customer lot, requiring strict separate accounting of customer material. The requirement to separate out U-236 to the maximum extent practical will require identification of U-235 fissile material crossover to the U-233 stream. U-233 material crossover 
to the U-235 stream will result in the loss of U-233 when the spent recycle U-235 material is retired. Both types of crossover must be identified for fuel recovery warranties. Fissile material inventory in unit operations is also important for criticality calculations.

4. Contaminant paths - Identification of paths of corrosive and erosive materials, as well as contaminants that may interfere with process operations, is important to equipment design and maintenance projections for the HRDF. Information on decay heat and activity associated with fission products is also important to design. The path of fission products is important to establishing shielding requirements.

5. Throughput rates - Achievement of recycle design throughput rates is important to fuel cycle economics and the operation of other fuel services such as fresh fuel manufacture and fuel shipping. Identification of required rates for verification in the development program or for scaleup projections is important. Very preliminary requirements are identified in this report to be further refined in future simulation studies of plant operations (HRDF Task 600 - CY-1977). Head-end required throughput for this report is based on 233 effective 24-hour operating days per year ( $80 \%$ availability, $90 \%$ efficiency, and 30 days accountability).

Not a11 of the items above can be projected for all unit operations at the present time due to insufficient experimental data. [Considerable experimental data that has been generated is applicable to carbide fuels of the FSV design (a11 TRISO coatings) and cannot be directly applied to the LHTGR fuel covered in this study.] Missing data can, however, be identified and factored into the development program where necessary. The unit operations are discussed individually below and the combined effect for head-end reprocessing in each of the above areas is summarized in Section 3.3. 


\subsubsection{Fue1 Element Crushing}

Figure 3-2 is a simplified diagram of fuel element crushing and crushed material transfer to primary burner feed. Details are given in Ref. 3-1.

1. Feed Material - The UNIFRAME Crushing System under development at General Atomic operates on the basis of whole HTGR fuel elements input to the primary crushing unit (Ref. 3-2). Since the exterior configuration of both standard and control fuel elements for both LHTGR and FSV designs can be considered identical for input to this system, no additional special feed material requirements are identified.

2. Throughput Rates - Phase I HRDF annual throughput rates of 10,000 fuel elements reprocessed annually (Ref. 3-3) require average crushing throughput of 43 fuel elements per day or approximately 2 per hour based on 233 operating days per year. Maximum required rates will be better identified in reprocessing operations simulation studies.

3. Waste Composition - Three possible waste streams are identified from crushing: 1) fission products and particulate matter possibly contained in the purge and conveying gas stream; 2) fission products and particulates possibly escaping at shroud penetrations; and 3) nonrecoverable material holdup in equipment removed for maintenance or retirement.

Data on the above items for prototypical equipment does not currently exist. Nonradioactive dust and particulate effects will be determined from UNIFRAME operating results during 1977 (Ref. 3-4). Hot engineering tests (HET) will provide comparative hot and cold fuel data in nonprototypical equipmene in about 1985 (Ref. 3-5). Therefore, only extrapolations from the above data are expected to be available for HRDF design. 
FUEL ELEMENTS FROM STORAGE

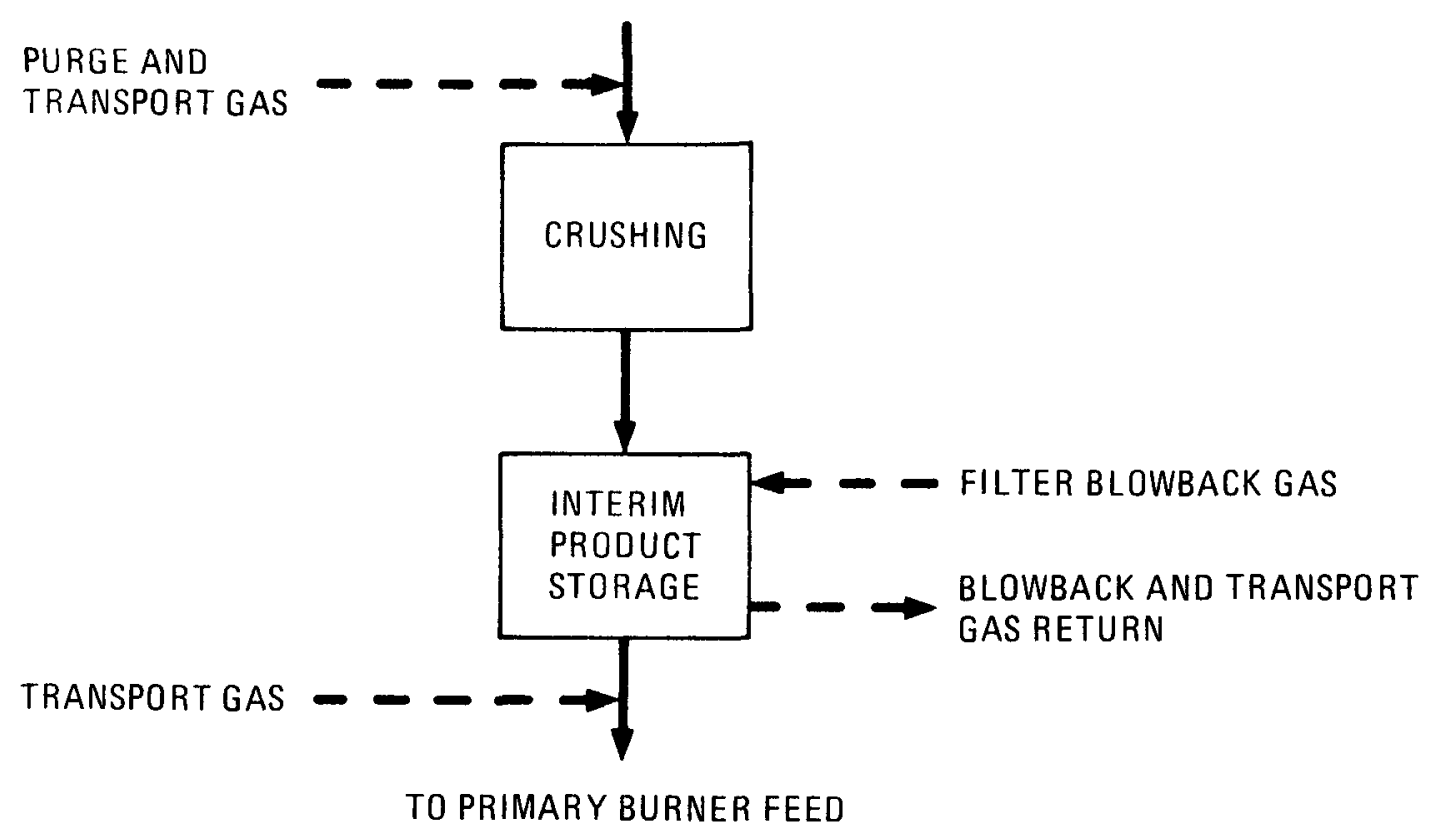

Fig. 3-2. Block diagram of fuel element crushing and material transport 
An estimate of krypton release during crushing was generated by ORNL (Ref. 3-6) in 1974 for FSV fuel. Extrapolating that data to current particle breakage assumptions for LHTGR fuel and current fuel element definitions (Ref. 3-7) would result in about $1 \times 10^{-5}$ grams per day of krypton released in the crushing step. Since this quantity is negligible compared with the total present, it has not been separately identified in material balances.

Activity plans for cold prototype crushing equipment indicate material holdup goals of $\leq 0.5 \%$ of initial throughput of a given batch for the crushing system (Ref. 3-8). Irradiated fuel behavior may be different due to decay heat effects and changes in physical and chemical properties. Therefore, comparative cold and hot fuel data from nonprototypical equipment in HET (Ref. 3-5) will be an important contribution to extrapolations for HRDF design. Assuming, at equilibrium operation, that all possible crevices are filled and material adhering to surfaces will be removed by gas flow at a rate equivalent to buildup results in negligible material holdup shown in the plant average daily material balance. No projections are included for loss with equipment removal because it is assumed that the bulk of material can be removed by vacuum or other devices required for cleanout for customer accountability.

\section{Special Nuclear Material Inventory}

Since fissile isotope composition in fuel elements and crushed fuel cannot be determined prior to the solution stage without extensive sampling and analysis of bulky and highly radioactive material, nuclear material safeguards and customer accountability projections are based on fuel element identification, manufacturing and burnup history, and weight comparisons between whole fuel element and crushed fuel element products. Projected annual uranium throughput is shown in Table 3-1 for combined Phase $I$ and Phase II of HRDF. All of this material must pass through the fuel element crusher(s). Applying 0.5\% material holdup (Ref. 3-8) to the first element of a customer lot (assuming equilibrium holdup is reached at this point) results in about $0.001 \%$ material loss per customer batch. Assuming the 
TABLE 3-1

AVERAGE ANNUAL URANIUM THROUGHPUT ( $\mathrm{kg}$ )

AT EQUILIBRIUM REPROCESSING OPERATION (a) (b)

\begin{tabular}{|c|c|c|c|c|c|c|c|c|}
\hline & \multicolumn{2}{|c|}{$\begin{array}{c}\text { From } \\
\text { M Standard } \\
\text { Elements } \\
(10,700 / y r)\end{array}$} & \multicolumn{2}{|c|}{$\begin{array}{c}\text { From } \\
\text { 23R Standard } \\
\text { Elements } \\
(8,780 / \mathrm{yr})\end{array}$} & \multicolumn{2}{|c|}{$\begin{array}{c}\text { From } \\
\text { 25R Standard } \\
\text { Elements } \\
(320 / y r)\end{array}$} & \multicolumn{2}{|c|}{$\begin{array}{c}\text { Total } \\
\text { LHTGR } \\
\text { E1ements } \\
(19,800 / y x)\end{array}$} \\
\hline & Fertile & Fissile & Fertile & Fissile & Fertile & Fissile & Fertile & Fissile \\
\hline $\mathrm{U}-232$ & 1.3 & NEGL & 1.1 & 1.0 & NEGL & NEGL & 2.4 & 1.0 \\
\hline $\mathrm{U}-233$ & 2260.1 & NEGL & 1854.9 & 282.4 & 67.6 & NEGL & 4182.6 & 282.4 \\
\hline $\mathrm{U}-234$ & 452.2 & 28.6 & 371.1 & 699.5 & 13.5 & 3.6 & 836.8 & 731.7 \\
\hline $\mathrm{U}-235$ & 92.2 & 695.8 & 75.6 & 277.0 & 2.8 & 16.3 & 170.6 & 989.1 \\
\hline $\mathrm{U}-236$ & 14.5 & 1231.6 & 11.9 & 141.2 & 0.4 & 337.3 & 26.8 & 1710.1 \\
\hline U-238 & 0.6 & 401.6 & 0.5 & 14.4 & NEGL & 89.6 & 1.1 & 505.6 \\
\hline TOTAL & 2820.9 & 2357.6 & 2315.1 & 1415.5 & 84.3 & 446.8 & 5220.3 & 4219.9 \\
\hline
\end{tabular}

$\underbrace{}_{\text {At } 93.4 \%}$

$(10,000 \mathrm{FE})$

$2636.4 \quad 2203.4$

Ref. 3-1 Material

Balance Basis

(a) Overstated in total by $\sim 15 \%$ due to neglecting control rod elements (distribution of control rod element types TBD).

(b) Fuel element composition from Ref. 3-7. 
material composition is equally distributed between fuel particles and graphite, about $0.1 \mathrm{~kg}$ of uranium per year would be lost in HRDF Phase I based on three types of fuel elements in a customer lot. This is purely conjecture at the present time. The percent of holdup and distribution between particles and graphite can be estimated by various means in cold prototype equipment. Irradiated fuel behavior differences can be projected from hot engineering tests in 1985 to further clarify this issue.

\section{Product Specification}

The fuel element crushing system must produce feed of a suitable size for primary burning. The burner feed requirement may partially conflict with minimization of particle breakage in the crusher product. Broken particles will contribute to fission product release in the crusher, transport mechanisms, and burner off-gas. Cumulative broken particle content will interfere with particle separation efficiency in the classifier and is a prime contributor to fissile/fertile stream crossover.

Approximately $0.4 \%$ of the BISO fertile particles and $0.7 \%$ of the TRISO fissile particles, on the average, are expected to be broken in incoming irradiated fuel elements (Ref. 3-9). The UNIFRAME development plan goal for cold fuel is $\leq 0.8 \%$ fertile particle and $\leq 2.6 \%$ fissile particle breakage (Ref. 3-10). Verification is expected in late 1977. Breakage differences in crushing irradiated fuel material can be partially identified in hot engineering tests (Ref. 3-5). Only early-segment FSV fuel with all TRISO coatings and different kernel composition (see Table 2-1) will be available in the hot engineering tests; therefore, additional definition may be required either from hot cell tests or from strength calculations for different types of irradiated fuel particles. Preliminary prototype burner operation indicates that feed material size requirements may be relaxed (Ref. 3-11). This may be beneficial in meeting minimum particle breakage goals. 
No attempt has been made in this review to extrapolate irradiation effects from crushing system particle breakage. The cumulative breakage for crusher product is, therefore, assumed to be $1.2 \%$ of BISO fertile particles and $3.3 \%$ of TRISO fissile particles for LHTGR fuel.

\section{Contaminant Paths}

All of the fission products and other contaminants contained in the irradiated fuel elements will pass through the crushing system. Possible alternate paths are described above under waste composition, together with the expected schedule for definition. For this review and Ref. 3-1, 100\% of the contaminants in the fuel element are considered to remain in the crusher product.

Process contaminants, such as eroded metal from crusher surfaces, will no doubt enter the product stream. Wear rate projections from cold prototype and hot engineering test operations may shed some light on this subject, but throughput levels may not be sufficient for accurate predictions. No attempt is made to project such contaminants in this study.

\subsubsection{Material Transport (Solids)}

Solid material transport consists of transfer and interim storage of solid feed and products for all dry head-end systems. Transport system routes and storage points identified in the current flow sheet review and material balance (Ref. 3-1) are summarized in Fig. 3-3, along with identification of the material to be transferred or stored and the assumed method of transport. Details are shown on PF-200-1, PF-200-2, and PF-200-3 in Ref. 3-1.

\section{Throughput Rates}

A $1 \mathrm{lb} / \mathrm{sec}(0.45 \mathrm{~kg} / \mathrm{sec})$ solids transfer rate based on 2 -in. 1ines and $95 \mathrm{ft} / \mathrm{sec}$ gas velocity is tentatively proposed for pneumatic transport (Ref. 3-12). This results in relatively insignificant additions to 
MATERIAL TRANSFERREQ

FUEL ELEMENTS

CRUSHED FUEL ELEMENTS

CRUSHEO FUEL ELEMENTS

CRUSHED FUEL ELEMENTS

BURNED BACK FUEL PARTICLES

BUANEO BACK FUEL PARTICLES

BURNEO BACK FUEL PARTICLES

BURNED BACK FUEL PARTICLES

FERTILE PARTICLE KERNELS

FERTILE PARTICLE KERNELS

FERTILE PARTICLE KERNELS

INSOLUBLE PRODUCTS

INSOLUBLE PRODUCTS
$--------$

SIC COATED PARTICLES

SIC COATED PARTICLES

SIC COATED PARTICLES

CRUSHED SIC COATED PARTICLES

CRUSHEO SIC COATEO PARTICLES

FISSILE PARTICIE KERNELS \& HULLS

FISSILE PARTICLE KERNELS \& HULLS

FISSILE PARTICLE KERNELS \& HULLS

INSOLUBLE PRODUCTS

SIC-COATED PARTICLES

SIC COATED PARTICLES

HULLS \& OTHER INSOLUBLE PRODUCTS

HULLS \& OTHER INSOLUBLE PRODUCTS

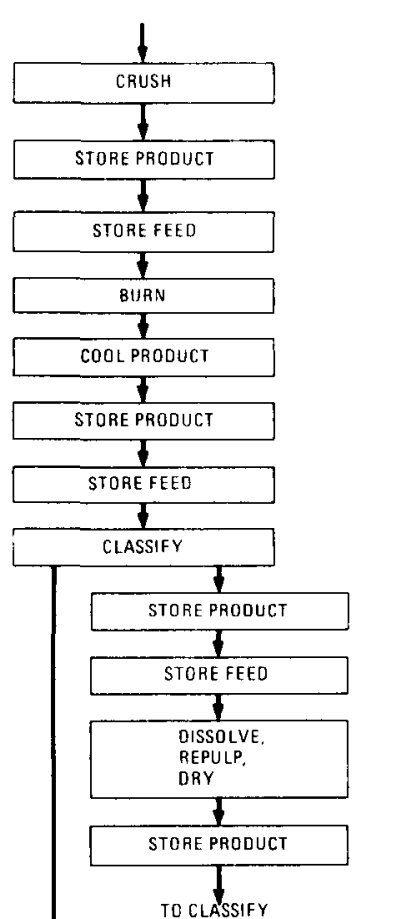

.

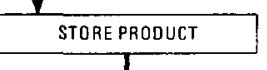

1

STORE FEED

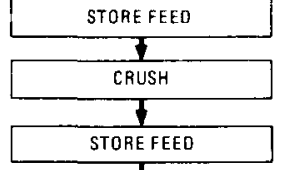

STORE FEED

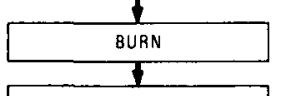

STORE PRODUCT

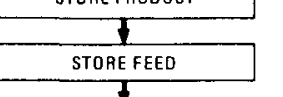

J

LEACH, REPULP, ORY

STORE FEEO

CLASSIFY

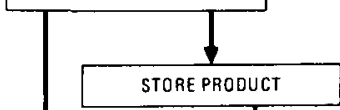

STORE PRODUCT

TO PARTICLE CRUSH

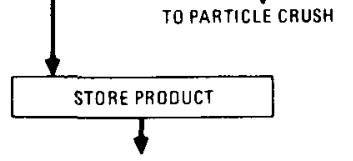

TO WASTE OR RECOVERY (TBD)
MODE OF TRANSFEH

TBD IN FUEL STORAGE SYSTEM

CRUSHER PURGE GAS

NEGATIVE PRESSURE

PNEUMATIC

GRAVITY

GRAVITY

PNEUMATIC

PNEUMATIC

GRAVITY

GRAVITY

PNEUMATIC

GRAVITY

PNEUMATIC

PNEUMATIC

CLASSIFYING GAS

PNEUMATIC

GRAVITY

GRAVITY

GRAVITY

GRAVITYIVACUUM PNEUMATIC

PNEUMATIC

GRAVITY

PNEUMATIC

GRAVITY

CLASSIFYING GAS

PNEUMATIC

GRAVITY

PNEUMATIC

Fig. 3-3. Transport system routes and storage points 
processing time for most transport operations. Surge storage requirements have not been quantified for this study because process simulation studies planned for late 1977 should provide guidance for HRDF design.

\section{$\underline{\text { Product Specification }}$}

Material transport, due to the multiplicity of operations, is potentially one of the most significant contributors to particle breakage. For simplicity in the current review only, a single transport operation has been assumed between any process and storage points. A reasonable target for particle breakage for the two transfers from fuel element crushing to primary burner feed storage has been set at 0.2 wt-\% BISO fertile particles and $2.0 \mathrm{wt}-\%$ TRISO fissile particles. Breakage in transport from burning to the classifier feed has been targeted at 0.3 wt-\% fertile kernels and 2.0 wt. $-\%$ burned-back TRISO fissile particles. A burner discharge cooling hopper has been added to the flow sheet, partially to reduce particle breakage attributable to introducing high-temperature $\left(\sim 800^{\circ} \mathrm{C}\right)$ particles into low-temperature transport gas streams.

Particle breakage to and from dissolver operations may also be significant. The fertile fraction will contain some quantity of burned-back TRISO fissile particles. A provision in the current flow sheet review has been made for recovery of the fissile particles from the other insolubles after drying; however, if these particles are broken in transit, their contents (including unburned carbon) may enter the fertile dissolver solution. The same rationale applies to the whole fissile particles remaining in the crushed particle stream to the fissile dissolver, since heavy metal carbides and nitric acid may form organic acids that will produce undesirable effects in solvent extraction. Particle breakage in transport from the insols dryer to the classifying stage could possibly result in particles that are difficult to separate from other insols for recovery. Data for these transfer operations is currently not available and particle breakage has been assumed to be negligible. 
Special Nuclear Material Inventory

Material holdup in lines and filters and material escaping filters represent possible loss mechanisms. Cold prototype activity plans indicate goals of $100 \%$ filter efficiency on particles $>2 \mu$ and greater than $95 \%$ recovery of material from preloaded filters (Ref. 3-13). The composition of the nonrecoverable filter material is unknown at present. Material behavior, including decay heat effects on the presence of semivolatile fission products, may vary significantly from cold test results. Examination of filters during or after cold prototype and hot engineering test operations is required to characterize, as well as quantify, the material 1oss. The possibility of uranium loss if particulates < $5 \mu$ pass through the filters needs to be determined, as well as the probable path for any lost material. Material plateout or holdup in transport lines and in hoppers needs to be determined and characterized for possible nuclear material loss, recovery requirements, and criticality considerations, both during normal operations and when failed equipment and/or piping is removed. Again, because of the multiplicity of transfers and hoppers, potential losses could be significant if provision is not made for cleanout or for recovery from cleanout and decontamination operations. Identification of losses will need to be extrapolated from cold prototype operations without radioactive material and from hot engineering tests with nontypical fuel. No projection is included in the material balances portion of this study.

Waste Stream Composition and Contaminant Paths

Waste streams from solid material transport include contaminated transport gases, replaced filters, and equipment or piping removed for repair or replacement.

No assessment of the transport gas system has been made in this review. The transport gas system has not been assessed to determine how much transport gas recycle is feasible. Gases will become contaminated and require periodic cleanup or removal. Possibly, separate supply systems should be 
provided since the crushed fuel element product should not contaminate as fast as the burner product stream, for example, because the majority of fission products should still be contained by particle coatings.

No attempt has been made to project gas stream contamination or, conversely, the contaminant contribution to the product streams from equipment erosion and corrosion.

\subsubsection{Fue1 Element Burning}

Figure 3-4 is a simplified diagram of fuel element (primary) burning and material transfer to particle separation (classifying). Details are given in Ref. $3-1$.

\section{Feed Material}

All of the crusher product is assumed to arrive at the burner in this study. Cumulative particle breakage at this point is assumed to be $1.4 \mathrm{wt}-\%$ of the BISO fertile particles and $5.3 \mathrm{wt}-\%$ of the TRISO fissile particles.

\section{Throughput Rates}

Material balances prepared during this study (Ref. 3-1) indicate an average daily burner discharge with fissile and fertile material equivalent to the average daily feed particle content. A semicontinuous operating mode is planned to reduce thermal cycling of the burner; that is, only part of the bed is discharged, leaving a bed heel to reduce startup time, minimize fines generation, and minimize temperature fluctuations between batches (Ref. 3-14).

Recent cold pilot plant work indicates that an $L / D$ of 2 is the minimum stable operating bulk bed height (Ref. 3-15). It has been tentatively recommended (Ref. 3-15) that the operating range for the primary burner lie between a minimum L/D of 2 and a maximum L/D of 4. For example, feeding 


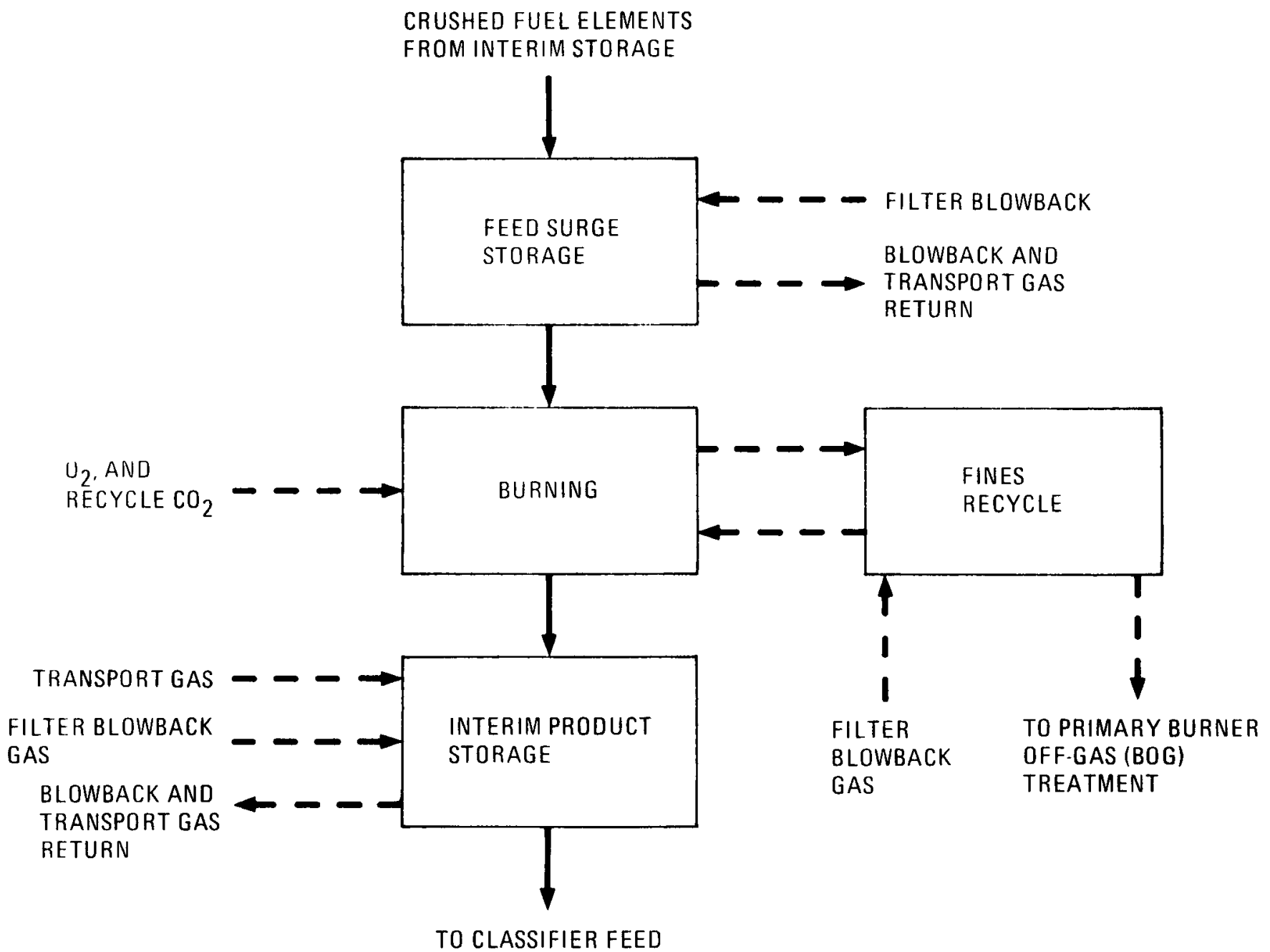

Fig. 3-4. Block diagram of fuel element burning and material transport 
and burning would continue for several days (depending on burner size) to build up a bed height of $L / D=4$. After tail burning, the bed would be partially removed to $>L / D=2$. Feeding would commence to build the bed to $\mathrm{L} / \mathrm{D}=4$, etc. The final withdrawal of a customer batch would then consist of the product from a bed of $L / D=4$.

The burn rate of material may be fairly constant. However, the burner operation throughput rate will also depend on the number of tail burn and partial bed removal cycles for a customer batch and the number of startups and complete bed removals occurring due to different types of elements in a customer batch. That is, initial core segments could be treated as a single batch for semicontinuous burner operation, but shipping and storage schedules may dictate at least two batches. When makeup segments also contain recycle fuel, separate burner runs will be required for makeup, 23RS, and 25RS elements, as well as any further splits that may occur as a result of shipping and storage scheduling. The Purex solvent extraction line will also require a continuous feed which may require a dedicated burner. Process simulation studies should help define the number of burners required to meet necessary plant throughput rates, as well as the required surge storage to accommodate sufficient burner product to provide a flow of feed to allow downstream operations to meet their required throughput rates.

Product

The operating mode described above may result in variation of product composition. Stratification in the bed may result in early dumps consisting largely of the more dense fertile fraction with a higher proportion of fissile particles and other noncombustibles in the later dumps. Cold prototype operations also indicate that the majority of unburned graphite in a batch is likely to appear in the first dump (Ref. 3-16). The daily output shown on the material balance averages out these variations, but they must be recognized in the design of downstream components. 
Additional particle breakage is targeted in the burning cycle as $0.1 \%$ fertile kernels and $4.5 \%$ silicon-carbide coated fissile particles. Fertile kernel breakage is important because the fragments will tend to classify into the fissile fraction. Fissile breakage is important to the expected volatile and semivolatile fission product release into the burner off-gas stream.

The burner product is expected to consist of burned-back (coatings removed) fertile kernels, fertile kernel fragments, burned-back (coating exterior to silicon-carbide coating removed) fissile particles, burned-back fissile kernels, and $\mathrm{SiC}$ hulls resulting from broken fissile particles, and approximately $1 \mathrm{wt}-\%$ unburned carbon (exclusive of the coatings interior to the SiC fissile coating). In attempting to project the unburned carbon path in later operations for the material balance, it is assumed that about $0.4 \mathrm{wt}-\%$ of the fertile kernels and burned-back fissile particles remain as unburned coatings; about 6 wt-\% of the fissile kernels and SiC hulls remain as unburned coatings; and the balance of the $1 \mathrm{wt}-\%$ of total burner product is free carbon and/or unburned graphite. Size distribution of the unburned graphite is important, because particles significantly larger than fuel particles may present plugging problems in wet head-end operations.

It is expected that some agglomerates will form. Agglomerate formation in cold prototype runs has been negligible (Ref. 3-16). Expected fission product eutectics when irradiated fuel is burned will not be characterized until the hot engineering tests are completed. No attempt has been made to project agglomerate formation for this study.

Formation of fission product compounds, activation product compounds, and other impurities and heavy metal compounds in the burner has not been characterized. For this study, it has been assumed that fission products and heavy metals from broken particles form oxides. Fissile particle uranium is assumed to form $\mathrm{U}_{3} \mathrm{O}_{8}$. Fertile particle uranium is expected to form some intermediate compound(s); however, for this study, it is assumed to be $\mathrm{UO}_{2}$. Boron is assumed to form $\mathrm{B}_{2} \mathrm{O}_{3}$. 
Waste Stream Composition and Contaminant Paths

The major waste stream from primary burning will be the burner off-gas. other waste will include material held up or plated out in equipment removed for repaix or replacement. No attempt is made in this study to project failed equipment waste streams.

Certain radioactive gases and volatile fission products are expected to be released in the burner and follow the off-gas stream. Following German experimental work on $\mathrm{ThO}_{2}$ fuels, projections for fertile particle release have been made as follows: $10 \%$ of the krypton, $20 \%$ of the tritium, and $4 \%$ of the iodine (Refs. 3-17 and 3-18). For this study, xenon release has also been assumed to be $10 \%$. In addition, it has been assumed that $100 \%$ of the above fission products are released from the broken fissile particles (Ref. 3-19).

For material balance purposes, the quantities shown for 180-day cooled fuel in Ref. 3-7 have been used for the above percentage applications. No attempt has been made in this study to project any changes in fission product quantity due to processing time lapses, even after separation from precursors. Such complexities are beyond the scope of a short-term study and will be assessed in on-going off-gas work.

Radon will also be released in the burner. The major contributor to the radon activity levels in LHTGR fuel is radon-220, which has a half life of only 56 seconds. However, it is continuously generated when U-232 and Pu-236 are present. Examination of the projected composition of 180-day, 1-year, 3-year, and 5-year cooled fuel (Ref. 3-7) indicates that the radon present is relatively constant over time, or that the generation rate is roughly equal to the decay rate. The radon released into the off-gas stream from any unit operation is therefore a function of batch size and process time. For example, a 24-in. burner in a semicontinuous operating mode could have particles from over 100 fuel elements present at any given time over many days. Therefore, stating radon as a function of average daily throughput rate on a "single-quantity" basis (the figure given in the spent fuel 
element definition of Ref. 3-8) could understate the off-gas radon component by several orders of magnitude. Radon release calculations require detailed studies including equipment sizing and batch or operating mode definition. Such calculations are beyond the scope of this study and radon quantities have not been included in the material balance.

Sulfur from the graphite and fuel rod matrix is assumed to volatilize in the burner and follow the off-gas stream (Ref. 3-19). Experimental verification of the form and quantity volatilized is required. Some $\mathrm{B}_{2} \mathrm{O}_{3}$ may volatilize, but no projection has been made for this study. Trace amounts of other possible volatile elements include chlorine, phosphorous, nitrogen, and bromine; however, their form and paths have not been projected in this study.

Several other fission products are also expected to volatilize in the primary burner, many perhaps cooling and condensing before reaching the offgas stream. The rate of emission of these semivolatiles is dependent on a number of burner operating parameters. Lack of definition for these parameters for irradiated fuel makes projections on forms and quantities of products present in the off-gas speculative at the present time. Some work on identifying semivolatile emissions has been done in hot laboratory-scale equipment on nonrepresentative (of Large HTGR) fuel (Refs. 3-20 and 3-21). Equipment configuration is also an important variable determining the semivolatile paths. More nearly representative equipment will be available in the hot engineering tests, but only FSV irradiated fuel will be available for testing. The TRISO coating on FSV fertile particles will interfere with obtaining semivolatile release information from the primary burner. A run with crushed TRISO fertiles to simulate BISO is planned (Ref. 3-5) but the carbide fertile particles in burning to a fine oxide powder will not typify LHTGR oxide particles, nor will fluidization characteristics be typical, again interfering with obtaining results for HRDF projections.

Carbon-14, an activation product, will evolve as ${ }^{14} \mathrm{CO}_{2}$. For material balance purposes, $\sim 90 \%$ of the $C-14$ in a fuel element (Ref. 3-8) is assumed 
to originate from graphite, matrix, and coatings, which are converted to gaseous combustion products in the primary burner.

During burner operations, an appreciable fraction (10-20\%) of the carbon will be converted to $\mathrm{CO}$, rather than fully oxidized to $\mathrm{CO}_{2}$. A hypothetical 24-in. burner operation was projected for material balance purposes which averaged out to $11.6 \%$ CO (Refs. 3-10 and 3-19). Occasional oxygen peaks ( $\sim 10 \%$ ) will occur in the off-gas during tail burning and partial bed removal. Over the hypothetical cycle, the $\mathrm{O}_{2}$ content of the stream averaged $0.2 \%$. The balance of the stream is assumed to be $\mathrm{CO}_{2}$ and the radioactive gases described above. Radioactive gas volume in the material balance was generally neglected as insignificant in the large $\mathrm{CO}_{2} / \mathrm{CO} / \mathrm{O}_{2}$ volume of the off-gas stream.

The balance of fission products and other contaminants are assumed to follow the burner product stream. No addition has been made to the stream in this study for added contaminants from equipment erosion and corrosion.

\section{Special Nuclear Material Inventory}

Some special nuclear material may be carried out in the off-gas stream. Broken fissile particles may result in a very fine uranium oxide powder. Cold prototype burner off-gas filters will remove all particulate matter $>1 \mu$ in diameter (Ref. 3-22). The quantity of fine material generated and its special nuclear material content, passage through filters, and holdup on filters cannot be quantified until larger scale hot laboratory and/or hot engineering tests are performed. Some characterization can be done on particulates in general in cold operations, but decay heat effects on material holdup in filters require hot laboratory work. Broken particle characterization will also be an important factor.

Cold prototype work indicates superfine material will adhere to burner system surfaces. Irradiated material may be even more cohesive. No doubt there will be a buildup of material that will at some point begin falling 
back into the material stream, and some of the material will be retrievable in inventory cleanout operations. Until nuclear content of material holdup and cleanout efficiencies are established, no projection of loss and/or required recovery techniques can be made. This type of information should be obtained in the hot engineering tests (Ref. 3-4); however, the tests will be on low-burnup TRISO/TRISO FSV fuel, which may significantly reduce decay heat effects on material holdup in the primary burner as compared to high burnup TRISO/BISO LHTGR fuel.

\subsubsection{Fuel Particle Separation (Classification)}

Figure 3-5 is a simplified diagram of fuel particle classification and material transfer to particle dissolution or to particle crushing. Details are given in Ref. 3-1.

\section{Feed Materia1}

All of the burner product is assumed to arrive at the classifier for this study. Cumulative particle breakage at this point is assumed to be $1.8 \%$ of the fertile kernels, $9.8 \%$ of the fissile stream as kernels and hulls, and $2 \%$ of the fissile stream as broken particles (SiC coatings broken and inner carbon coatings exposed), broken in transit after leaving the burner.

\section{$\underline{\text { Product }}$}

All of the material is assumed to leave the classifying operation as either the fissile or fertile fraction product stream. An additional $0.5 \%$ of the burned-back fissile particles are assumed to break in classifying. The following crossover assumptions are made (Ref. 3-19):

1. $1.5 \%$ of whole fertile kernels to the fissile stream.

2. $75 \%$ of broken fertile kernels and $100 \%$ of broken fissile particles to the fissile stream.

3. $2 \%$ of whole burned-back fissile particles to the fertile stream. 


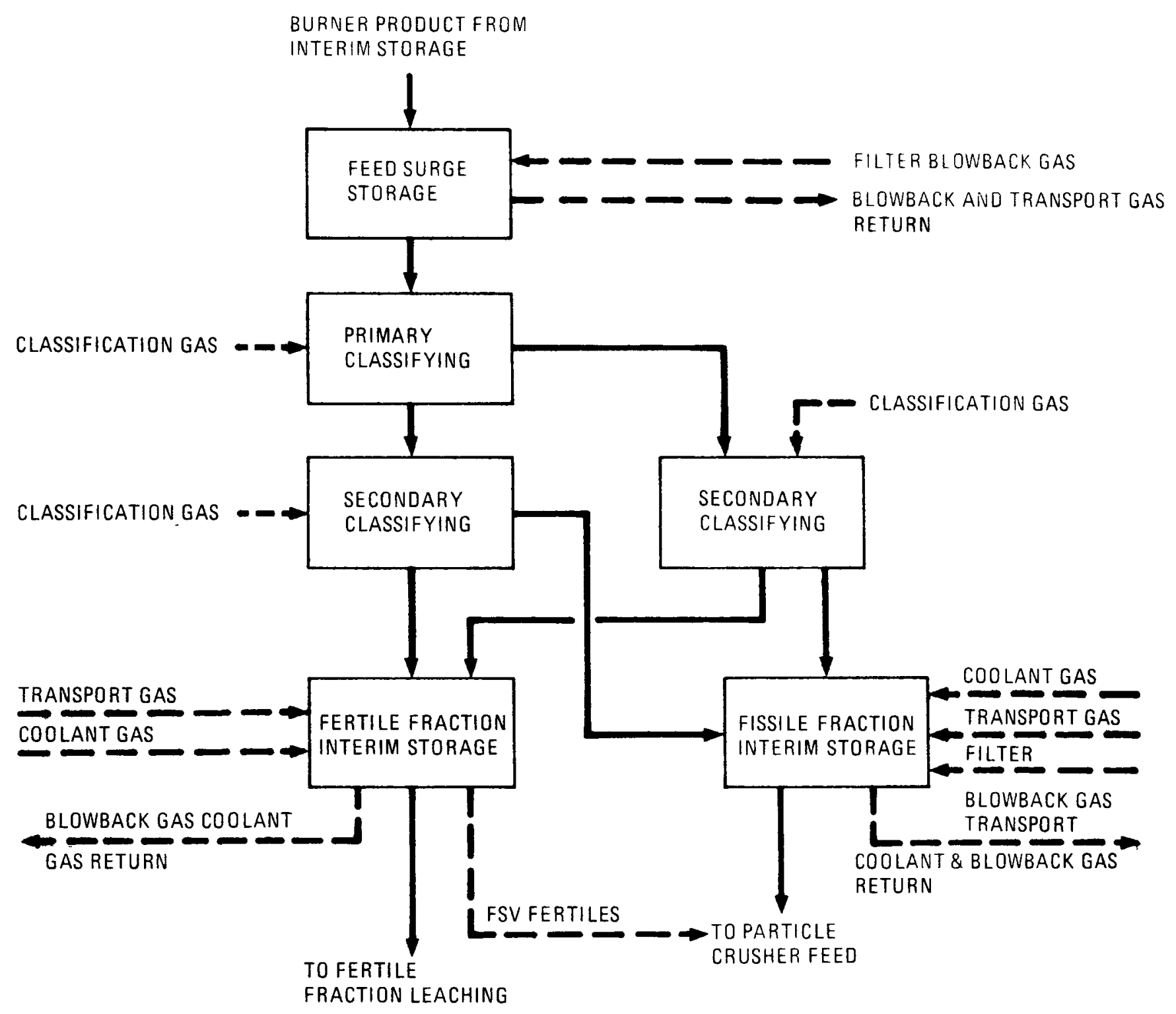

Fig. 3-5. Block diagram of fuel particle classifying 
Unburned carbon directly associated with the particles and hulls (Section 3.2.3) is assumed to follow the respective associated product stream; $98 \%$ of the free carbon is assumed to follow the fissile overhead product stream. In the material balance, the $2 \%$ in the bottom stream is negligible and the separation does not appear. All of the boron is assumed to follow the fissile overheads stream as $\mathrm{B}_{2} \mathrm{O}_{3}$. (Experimental work is needed to establish the path of the boron.) All of the above are the total product goals after the secondary classifying stage.

\section{Special Nuclear Material Inventory}

Possible special nuclear material loss mechanisms include holdup in equipment, transport lines, and filters as discussed in Section 3.2.2. No projection has been made for these losses.

The reference recycle design basis includes the retirement of the fissile fraction from spent $U-235$ refabricated fuel elements. This could represent about $16 \mathrm{~kg} / \mathrm{yr}$ of fissile U-235 (Table 3-1) at equilibrium operating conditions or about $0.3 \%$ of the U-233/U-235 throughput. The loss could be a great deal higher in early plant operating years when there is a higher percentage of 25RS fuel. In addition, when the 25RS particles are separated by classification, $1.5 \%$ of the whole fertile kernels and $75 \%$ of the broken fertile kernels in the 25RS fuel elements are expected to follow the fissile stream, representing an additional possible loss of $2 \mathrm{~kg} / \mathrm{yr}$ of $\mathrm{U}-233$ or $0.04 \%$ of the U-235/U-233 inventory.

\section{Waste Streams}

Waste streams include possible contaminant contribution to the conveying/classifying gas supply, material held up in equipment removed for repair or replacement, and the retired 25RS fissile particles. On the average, at equilibrium the retired fissile particles will represent about $3200 \mathrm{~kg} / \mathrm{yr}$ of high-level sold waste (before any additions for conversion to a form acceptable to a federal repository). 


\section{Throughput Rate}

A $2-\mathrm{kg} / \mathrm{min}$ solids separation rate is projected for pneumatic classification (Ref. 3-13). This results in approximately 5 hours per day in which to process the average daily throughput. However, as discussed in Section 3.2.3, burner product removal is likely to be at less-than-daily intervals. The classifying operation may then take several hours to process more than one day's throughput. Process simulation and surge storage studies will better define the preferred operating mode.

\subsubsection{Fertile Fraction Leaching}

Figure 3-6 is a simplified diagram of fertile fraction leaching for LHTGR fuel (FSV fertile particles are TRISO-coated, requiring particle crushing and burning before dissolution). Details of fertile fraction leaching are given in Ref. 3-1.

\section{Feed Materials}

Dissolver feed material is the fertile fraction from fuel particle classification, including burned-back fertile kernels with small percentages of associated unburned carbon, fissile particles burned back to the SiC coating, and free carbon from unburned graphite.

A potassium fluoride-aluminum nitrate-cadmium nitrate (poison) Thorex solution is combined with recycle nitric acid and recycle water to produce a 13 molar $\mathrm{HNO}_{3}, 0.05$ molar $\mathrm{F}^{-}, 0.1$ molar $\mathrm{Al}^{++}, 0.075$ molar $\mathrm{Cd}^{++}$dissolving solution. Sufficient solution is added to produce an approximately $1 \underline{M}$ thorium product after dissolving. After dissolution and separation of insoluble materials from the decanted dissolver solution in a centrifuge, the insols are repulped with an 0.2 molar poisoned nitric acid solution to increase the heavy metal recovery. The required dilute acid feed is based on the quantity of solution required to transport the insols as a slurry; $\sim 50$ liters of solution is required for each $7 \mathrm{~kg}$ of insols (Ref. 3-23). 


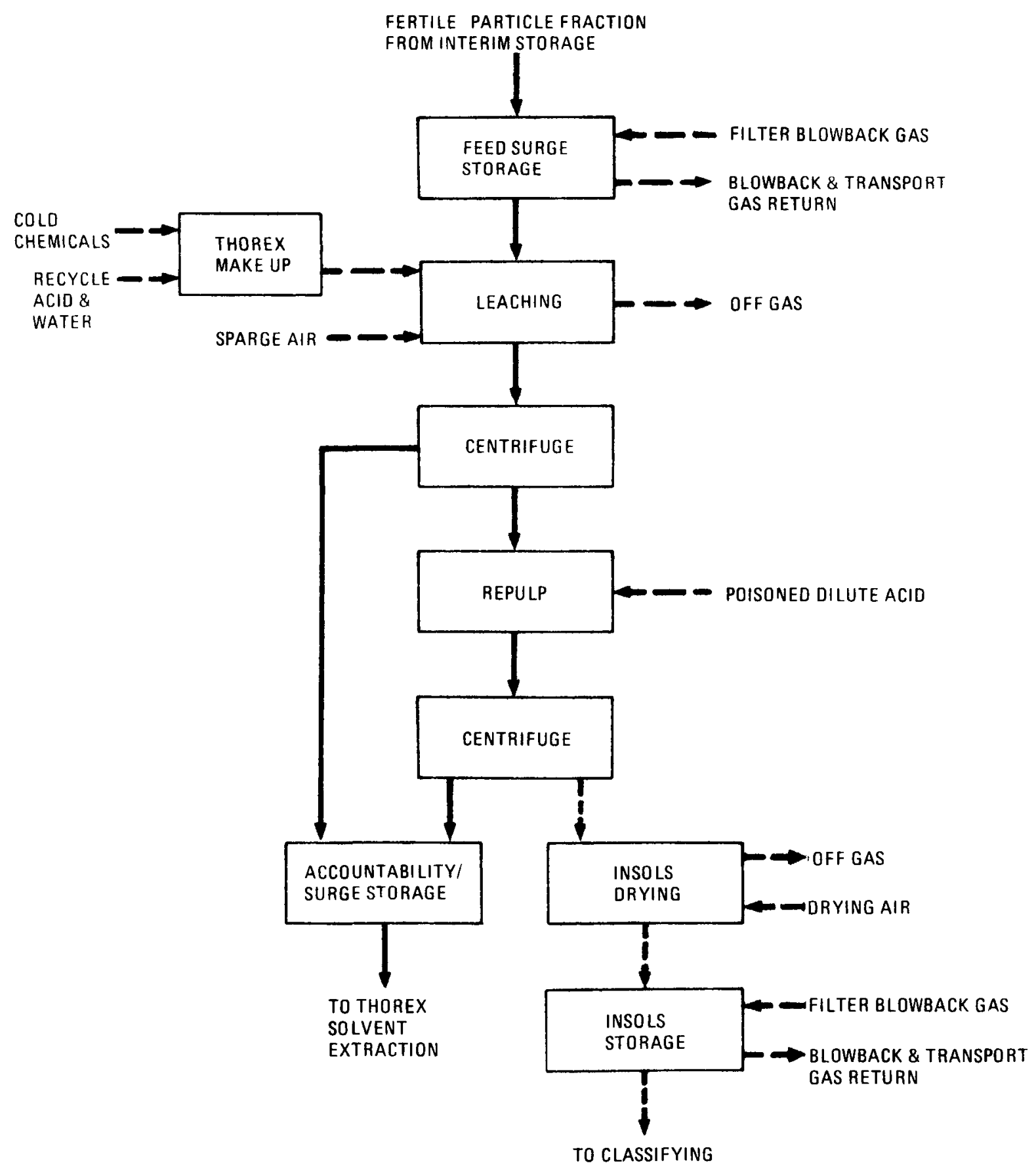

Fig. 3-6. Block diagram of fertile fraction leaching 


\section{Product}

The Thorex solution/fertile fraction slurry is heated and sparged in the dissolver until an approximately 1 molar thorium solution is achieved (Ref. 3-24). The dissolver product solution is diluted slightly by the repulping solution but the final product is still nearly 1 molar thorium and $\sim 8.4$ molar $\mathrm{HNO}_{3}$.

Table 3-2 indicates the assumed heavy metal, fission product, and other insoluble product paths assumed for this study. Dissolution rates and efficiencies and fission product paths for Thorex dissolution will be projected from cold pilot work and extrapolation from nonrepresentative fuels in hot engineering tests. For the current study, LWR fuel dissolution results (Ref. 3-25) have been used to project yields. These results are from full-burnup uranium oxide fuel and might be expected to be more typical of the fissile fraction leaching.

\section{Throughput Rates}

The fertile fraction average daily throughput is assumed to dissolve in a 24-hour period. Dissolution rates are not well established for typical irradiated fuels, nor has a size been specified for the dissolver and other leaching unit equipment. The heel mode of operation currently being investigated at General Atomic would include partial removal of dissolver solution and feed addition at intervals during a customer lot dissolving cycle. The heel operating mode is expected to significantly shorten dissolution time. The reduced time would allow equipment size reduction and the average daily throughput of fertile fraction would still be dissolved in a 24-hour period. 
TABLE 3-2

ASSUMED DISTRIBUTION OF HEAVY METALS, FISSION PRODUCTS, AND INSOLUBLES IN FERTILE FRACTION DISSOLUTION

\begin{tabular}{|c|c|c|c|c|c|c|}
\hline & \multirow{2}{*}{\multicolumn{3}{|c|}{ Daily Throughput (a) }} & \multicolumn{3}{|c|}{ Percent of Total in Fraction } \\
\hline & & & & \multirow{2}{*}{$\begin{array}{r}\text { Dissolver } \\
\text { Solution }\end{array}$} & \multirow{2}{*}{$\begin{array}{l}\text { Repulping } \\
\text { Solution }\end{array}$} & \multirow[b]{2}{*}{ Insolubles } \\
\hline & Grams & Curies & Watts & & & \\
\hline Fissile particles & 3,600 & 26,100 & 114 & -- & -- & 100.0 \\
\hline Free carbon & 1,700 & NEGL & NEGL & 25.0 & -- & 75.0 \\
\hline Uranium & 11.007 & 97 & 6 & 99.5 & 0.495 & 0.005 \\
\hline Thorium & 331,360 & 58 & 2 & 99.5 & 0.495 & 0.005 \\
\hline Protactinium & 11 & 171,964 & 420 & 99.5 & 0.495 & 0.005 \\
\hline Other actinides & 4 & 19 & NEGL & 99.5 & 0.495 & 0.005 \\
\hline Europium & 26 & 1,748 & 7 & 99.5 & 0.49 & 0.01 \\
\hline $\begin{array}{l}\text { Cerium/ } \\
\text { Praseodymium }\end{array}$ & 1,827 & 756,408 & 3,010 & 99.5 & 0.49 & 0.01 \\
\hline Promethium & 53 & 50,589 & 26 & 99.5 & 0.49 & 0.01 \\
\hline Other lanthanides & 2,175 & 194 & 1 & 99.5 & 0.49 & 0.01 \\
\hline $\begin{array}{l}\text { Palladium/ } \\
\text { rhodium/ruthenium }\end{array}$ & 629 & 63,890 & 239 & 50.0 & 5.0 & 45.0 \\
\hline
\end{tabular}

(a) Based on Ref. 3-7, 180-day cooled fuel discharged at reactor Reload 13. 
Waste Stream Composition and Contaminant Paths

Waste streams for fertile particle leaching include:

1. Dissolver off-gas

2. Insoluble materials (insols)

3. Material held up in equipment removed for repair or replacement

4. Insols dryer off-gas

5. Insols dryer off-gas condensate

All of the iodine, krypton, and xenon in soluble materials in the dissolver is expected to follow the off-gas stream. While some of the iodine will, no doubt, be returned by the reflux condenser, LWR program data with irradiated $\mathrm{UO}_{2}$ fuel dissolution indicates that $99.5 \%$ of the iodine can be driven off (Ref. 3-26).

No compounds are formed and released from the dissolver. For the material balance, an $80 \%$ scrubbing efficiency has been assumed in the reflux condenser (Ref. 3-19).

As discussed for the primary burner waste stream composition (Section 3.2.3), radon production and decay are essentially steady state as long as Th-228 is present, leading to considerable uncertainty as to the quantities of radon released over time in various process operations. Calculations require equipment sizing and operating mode definition beyond the scope of this study; hence, no projections for radon are included in the material balance.

In secondary burning, $90 \%$ of the carbon-14 projected to be in the fissile fraction is assumed released ( $10 \%$ being released in primary burning from broken fissile particles).

Insoluble materials assumed for this study are indicated in Table 3-2. A simplifying assumption has been made that all fertile particles are sufficiently burned back to be $100 \%$ dissolved. No doubt, a certain percent 
of undissolved or partially dissolved fertile kernels may be present as well. Due to the expected fissile particle content, the current flow sheet (Ref. 3-1) indicates return of the insols to pneumatic classification for recovery of the fissile particles. Several uncertainties exist, including insols size and density distribution and possible fissile particle breakage in various operations after initial classification. Recovery of fissile particles in this stream has therefore not been factored into material balances for this study.

In addition to uncertainty in the percentage distribution of material to the insols projected in Table 3-2, certain fallacies are introduced into the material balance by ignoring processing time intervals. For example, protactinium is a major contributor to the activity levels shown for the insols in the material balance; however, it has a 27-day half life and its precursor, thorium-233, is essentially absent at 180-day cooldown. Any substantial delay in processing time beyond 180 days after reactor discharge could greatly reduce the protactinium activity contribution to both the insols and the dissolver solution. The activity level of the insols at processing time also cannot be directly projected to waste disposal since many of the high-activity products have relatively short half lives. Detailed analyses, including storage time, will be required to project activity levels upon transfer to repositories.

Insols drying as a unit operation is not currently defined. Insols dryer off-gas composition and the resulting condensate waste stream have not been projected for this study. Waste associated with failed equipment has not been identified.

Some contaminant paths have been defined in Table 3-2 and in the offgas discussion above. All other contaminants are assumed to be in solution in the leaching system product. No attempt has been made to identify corrosion products or undesirable compounds that might be formed during dissolution. Development programs will define corrosion for various candidate equipment materials. Corrosion assessment should include the effects 
of hydrogen evolution, temperature, stream velocity, stream concentration, time, and impurities (such as the aluminum ions included as corrosion inhibitors, as well as impurities that may accelerate corrosion).

\section{Special Nuclear Material Inventory}

Leaching product solution represents the initial major accountability point in the process by analytical measurement of special nuclear material content. It also represents the first customer accountability point for fissile isotopes. Analytical measurement uncertainty on solutions containing a full range of fission products, activation products, and heavy metals will contribute to uncertainty in inventory accounting. Commercial plant measurement accuracy limits for HTGR fuel have been proposed at $1 \%$ for U-235 (Ref. 3-27). U-233 measurement technology development is not as advanced and no projection can currently be made. In other words, physical losses can only be established with a certain degree of accuracy, contingent on sampling, analytical, and calculational techniques employed. (See Section 3.2.8.)

Potential loss mechanisms in the fertile fraction leaching operation include material volatilized (or carried out with other volatiles) in the dissolver and/or insols dryer off-gas streams, material held up in equipment removed for repair or replacement, and material lost to waste with the insolubles.

For the current study, $0.005 \%$ of the fertile fraction uranium and plutonium are considered insoluble. The loss to insols requires better definition because there may be a requirement for further processing of insols if the special nuclear material content is high.

About $3.6 \mathrm{~kg}$ per day of fissile particles are projected to be in the fertile fraction insols. Some recovery will be effected through classification and rework; however, $100 \%$ recovery would be unlikely. (It could be essentially zero if the fissile particles broke in transport and could not 
be separated). The recovery stream has not been projected for this study or for the material balance.

\subsubsection{Fuel Particle Crushing and Burning}

Figure 3-7 is a simplified diagram of fissile particle crushing and burning and material transfer to fissile particle leaching operations. Details of fissile and FSV fertile particle crushing and burning are given in Ref. 3-1.

\section{Feed Material}

Fissile particle crusher feed material is the fissile fraction from fuel particle classification, including whole and broken fissile particles burned back to the SiC coating and fissile kernels and hulls with some associated unburned carbon. About $1.5 \%$ of the whole fertile kernels, $75 \%$ of the broken fertile kernels, $98 \%$ of the free carbon left in primary burning, and $100 \%$ of the $\mathrm{B}_{2} \mathrm{O}_{3}$ are assumed to be in the fissile fraction.

\section{$\underline{\text { Product }}$}

It is projected that $1 \%$ of the whole fissile particles will remain uncrushed and unburned (Ref. 3-28). Unbroken particles will, no doubt, be a function of crusher wear rate and vary over time; the $1 \%$ goal is an ayerage figure. The burner product is assumed to contain 1 wt-\% unburned carbon. Approximately $100 \%$ of the tritium, iodine, krypton, and xenon in the crushed fissile particles is assumed to volatilize (Ref. 3-29).

No projection has been made for semivolatiles release; the balance of the fission and activation products and heavy metals is assumed to be in the burner product stream.

Agglomerate formation in the secondary burner has not been projected for this study. Larger scale hot laboratory tests and hot engineering tests 


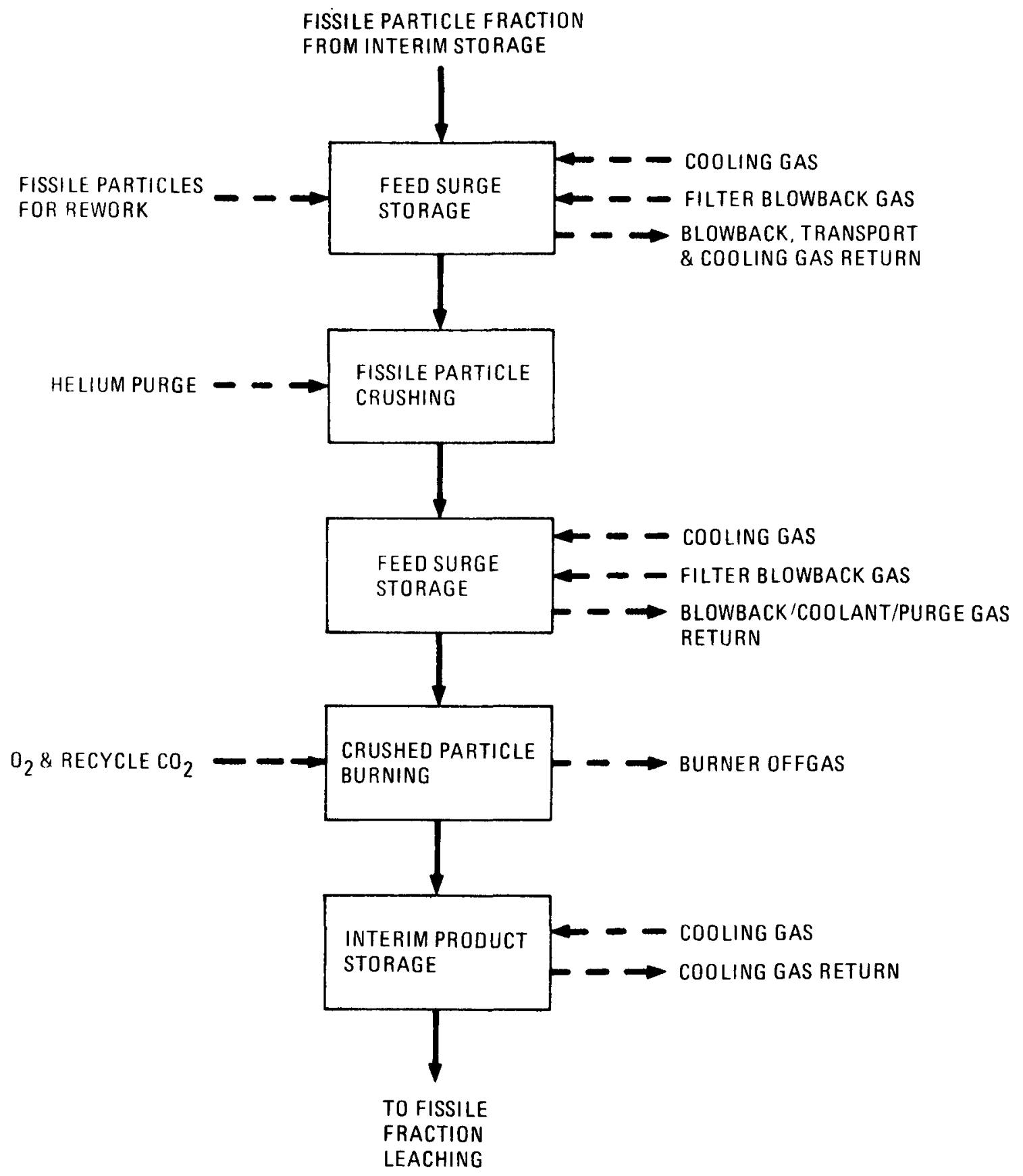

Fig. 3-7. Fissile fraction particle crushing and burning 
should at least qualitatively define the forms of agglomerates likely to appear, although projecting quantities from nontypical fuel may not be possible.

\section{Throughput Rates}

Cold pilot work on FSV fertile particles has indicated that crusher roll speed does not significantly affect product size distribution (Ref. 3-11). Using a conservative $40-\mathrm{kg} / \mathrm{hr}$ throughput rate allows the average daily throughput to be processed in about 5 hours operating time. The average daily throughput of crushed feed ( $210 \mathrm{~kg}$ ) is assumed to be burned in four 5.5-hour batches (Ref. 3-19).

\section{Waste Stream Composition}

The waste streams identified for particle crushing and burning include coolant/purge/conveying gas contamination, material held up in equipment removed for repair or replacement, and the burner off-gas stream.

Conveying/coolant/purge gas waste streams have not been addressed in this study. The majority of possible contamination from crushing should flow into the secondary burner in the arrangement shown in Ref. 3-1. The major effect on the material balance is the neglect of the helium flow in the burner off-gas stream composition.

Table 3-3 indicates the assumed average particle burner off-gas composition over a LHTGR-type fuel batch operation, exclusive of helium added by the feed operation. Peak co flows over shorter time periods may considerably exceed the average. Approximately $100 \%$ of the tritium, iodine, and krypton remaining in the fissile fraction is expected to volatilize in the burner and enter the off-gas stream (Ref. 3-29). No additional release is projected from the small quantity of fertile kernels and uncrushed fissiles in the burner. Radon release has not been projected. No attempt has been made to project semivolatile release and paths since most of the experimental 
TABLE 3-3

PARTICLE BURNER TYPICAL OFF-GAS FLOW

(From Ref. 3-19)

\begin{tabular}{l|c|c|c|c}
\hline \multirow{2}{*}{ Operation } & \multirow{2}{*}{$\begin{array}{c}\text { Duration } \\
(\mathrm{hr})\end{array}$} & \multicolumn{3}{|c}{ Percent Composition (a) } \\
\cline { 3 - 5 } & 0.5 & $\mathrm{CO}_{2}$ & $\mathrm{CO}$ & $0_{2}$ \\
\hline Feeding & 1.0 & 99.7 & 0.3 & 0 \\
Start-up & 1.5 & 93.0 & 3.0 & 0 \\
Steady State & 1.0 & 57.8 & 6.8 & 0 \\
Tail Burn & 1.0 & 76.2 & $\sim 0$ & 42.2 \\
Soak & 0.5 & 100.0 & 0 & 23.8 \\
Shut-down & 5.5 & 81.8 & 4.3 & 13.9 \\
\multicolumn{1}{c}{ Average } & & & & 0 \\
\hline
\end{tabular}

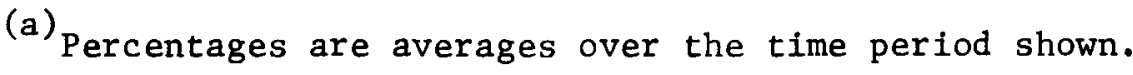


work on semivolatiles has been on nontypical (of LHTGR) fuels and/or in nontypical or laboratory-scale equipment. Activity levels and decay heat projected in the material balance are, therefore, understated by any semivolatile contribution.

\section{Special Nuclear Material Inventory}

Possible special nuclear material loss mechanisms include various coolant and conveyor gas streams, burner off-gas, holdup in filters, and holdup in equipment removed for repair or replacement.

Projections for the above loss mechanisms have not been included in the material balance because data is not generally available. The particle crushing activity plan (Ref. 3-28) sets a goal of $\leq 0.5 \%$ of the total material throughput unaccounted for when processing FSV fuel. The special nuclear material content of the "material unaccounted for" requires definition and verification for LHTGR fuel. Cold pilot plant tests will characterize material holdup for heavy metal content. Decay heat effects and the effect of semivolatile fission products will be extrapolated from hot engineering tests to project holdup for HRDF.

Burner filters are expected to remove $100 \%$ of $\geq 1 \mu \mathrm{m}$ and $98 \%$ of $>0.4 \mu \mathrm{m}$ particles from the off-gas stream. Cold pilot smear tests for radioactive thorium material indicate there may be no breakthrough of special nuclear material. The special nuclear material holdup on filters, particularly in the presence of decay heat, is not known. Some of this information will come from hot engineering tests, again with nontypical fuel forms (see Table 2-1).

\subsubsection{Fissile Fraction Leaching}

Figure 3-8 is a simplified diagram of fissile fraction leaching and accountabllity. Details of fissile and FSV fertile particle leaching are given in Ref. 3-1. 


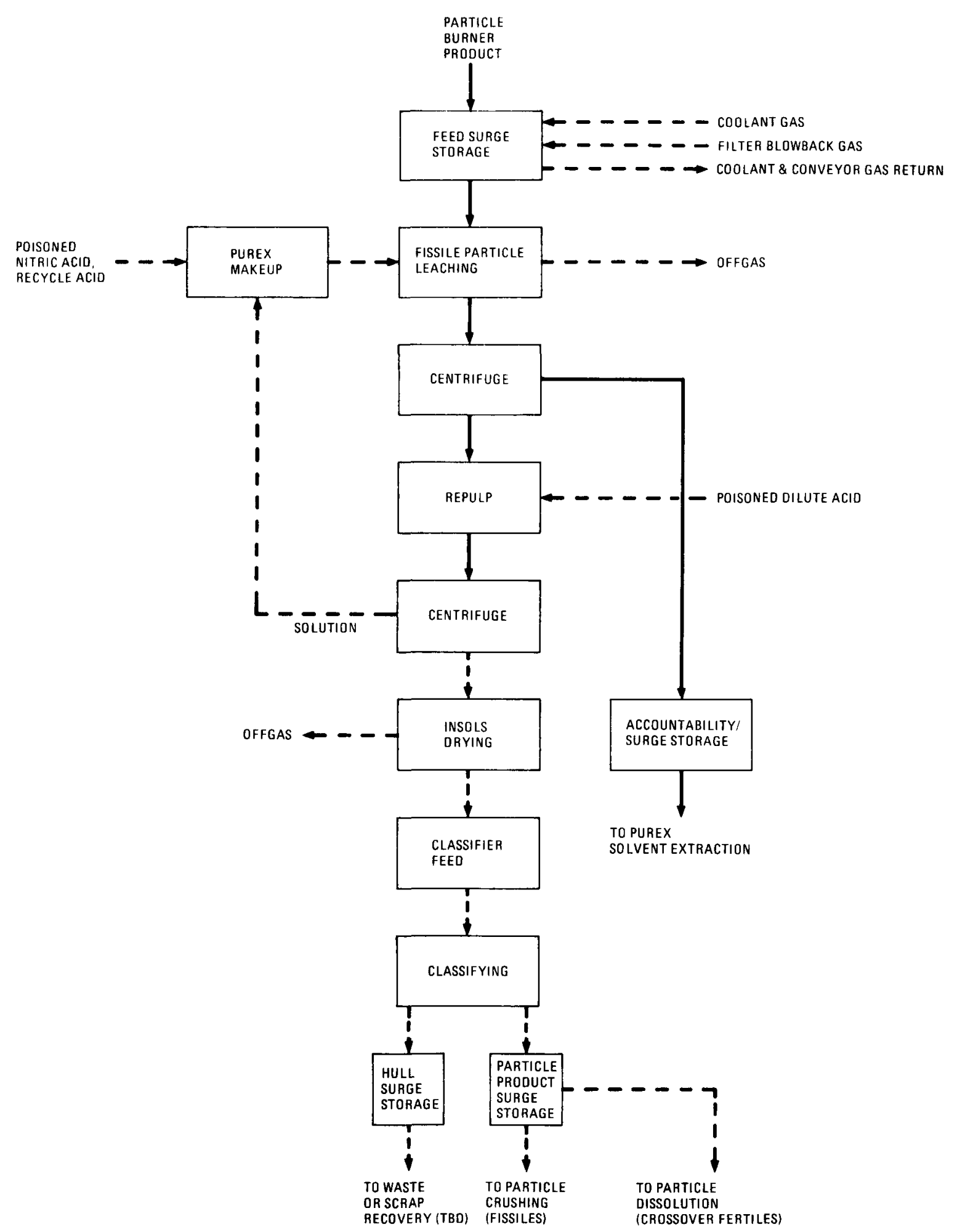

Fig. 3-8. Block diagram of fissile fraction leaching 


\section{$\underline{\text { Feed Material }}$}

The fissile fraction leaching feed consists of $100 \%$ of the crushed particle burner product (assumed to include uranium), heavy metal and fission product oxides, silicon carbide hulls, fertile kernels (from crossover into the fissile fraction), uncrushed and unburned fissile particles, boron as $\mathrm{B}_{2} \mathrm{O}_{3}$, and about 1 wt-\% unburned carbon. Some mixed agglomerate material is expected, but has not been projected for this study. Some of the whole fissile particles are expected to break in transport, exposing inner carbon coatings; however, breakage has not been projected beyond the classifier at this time.

Solution feed consists of poisoned 2.5 molar nitric acid mixed with 0.2 molar nitric acid repulping solution and approximately 10.5 molar recycle nitric acid, to produce an approximately 2 molar nitric acid final product after dissolution. The quantity of repulping solution necessary to move the large insols fraction (about 1000 liters/day) would dilute the product excessively; therefore, the repulping wash is returned as part of the dissolver makeup rather than added to the dissolver product stream. Only the final repulping solution from a customer lot will be sent directly to the accountability tanks.

\section{Product}

The concentration of the fissile leaching product solution is fissionproduct-limited. The product must also be approximately 2 molar $\mathrm{HNO}_{3}$ to avoid the need for a solvent extraction feed adjustment step. Combining these criteria with the solution feed specifications given above results in a fission product concentration about twice that of the fertile leacher and a concentration of about 0.035 molar uranium. Table 3-4 indicates the assumed heavy metal, fission product, and other insoluble product paths assumed for this study. As a simplification, fertile particle content (from crossover) is assumed to be $100 \%$ in the insols. A very small fraction of the $\mathrm{ThO}_{2}$ kernels may dissolve, but a percentage has not been projected. 
TABLE 3-4

ASSUMED DISTRIBUTION OF HEAVY METALS, FISSION PRODUCTS, AND INSOLUBLES IN FISSILE FRACTION LEACHING

\begin{tabular}{|c|c|c|c|c|c|c|c|}
\hline & \multirow{2}{*}{\multicolumn{3}{|c|}{ Daily Throughput (a) }} & \multicolumn{4}{|c|}{ Percent of Total in Fraction } \\
\hline & & & & \multirow{2}{*}{$\begin{array}{r}\text { Dissolver } \\
\text { Solution } \\
\end{array}$} & \multirow{2}{*}{$\begin{array}{r}\text { Repulping } \\
\text { Solution } \\
\end{array}$} & \multirow[b]{2}{*}{$\mathrm{Hu} 1 \mathrm{ls}$} & \multirow{2}{*}{$\begin{array}{l}\text { Other } \\
\text { Insols } \\
\end{array}$} \\
\hline & Grams & Curies & Watts & & & & \\
\hline $\begin{array}{l}\text { SiC-coated } \\
\text { fissile } \\
\text { particles }\end{array}$ & 1700 & 15347 & 67 & & & & 100 \\
\hline Fertile kernels & 11700 & 61016 & 228 & & & & 100 \\
\hline SiC hulls & 87900 & -- & -- & & & 100 & \\
\hline Free carbon & 1400 & NEGL & NEGL & 25 & & & 75 \\
\hline Uranium & 9219 & 1 & NEGL & 99.4 & 0.495 & 0.1 & 0.005 \\
\hline $\begin{array}{l}\text { Thorium/ } \\
\text { protactinium }\end{array}$ & NEGL & NEGL & NEGL & 99.4 & 0.495 & 0.1 & 0.005 \\
\hline Plutonium & 434 & 7652 & 162 & 99.4 & 0.495 & 0.1 & 0.005 \\
\hline Other actinides & 603 & 1059 & 38 & 99.4 & 0.495 & 0.1 & 0.005 \\
\hline Europium & 66 & 4856 & 20 & 89.5 & 0.49 & 10 & 0.01 \\
\hline $\begin{array}{l}\text { Cerium/ } \\
\text { praseodymium }\end{array}$ & 2843 & 661633 & 2668 & 89.5 & 0.49 & 10 & 0.01 \\
\hline Promethium & 47 & 44173 & 23 & 89.5 & 0.49 & 10 & 0.01 \\
\hline $\begin{array}{l}\text { Other } \\
\text { lanthanides }\end{array}$ & 4396 & 196 & NEGL & 89.5 & 0.49 & 10 & 0.01 \\
\hline $\begin{array}{l}\text { Palladium/ } \\
\text { rhodium/ } \\
\text { ruthenium }\end{array}$ & 1821 & 67680 & 289 & 45.0 & 4.5 & 10 & 40.5 \\
\hline
\end{tabular}

(a) Based on Ref. 3-7, 180-day cooled fuel discharged at reactor Reload 13. 
Fission product and heavy metal content in the silicon carbide hulls follows projections by Lin (Ref. 3-30). Otherwise, LWR fuel dissolution results (Ref. 3-25) from high-burnup uranium oxide fuels have been used to project yields. Several types of uranium-bearing materials will, at various times, be in the insols, including uncrushed and unburned silicon-carbide coated fissile particles or FSV fertile particles and undissolved or partially dissolved LHTGR fertile particles (from crossover into the fissile stream). A classifying step for recovery of these materials for rework has been included in the current flow sheet (Ref. 3-1). No projection of the recovery efficiency has been made for this study since the insols product has not yet been characterized. Of particular concern may be the form and density of fission product eutectics included in the product, and particle and/or kernel breakage in various unit operations and transports.

\section{Throughput Rates}

It is assumed that the average daily throughput of burner product can be dissolved in one or more batches within a 24-hour period. Centrifugation requires about 30 minutes. A more limiting factor may be sample turnaround time at the accountability tanks. It is assumed that techniques can be developed that can handle the required quantity of samples in 24 hours. Rework rates for recovered undissolved particles have not been projected. Process simulation studies should establish whether rework material can be customer-batched or whether it will represent a plant "stock" for which customers are reimbursed.

Waste Stream Composition and Contaminant Paths

Waste streams for fissile fraction leaching include:

1. Dissolver off-gas

2. Insols

3. Insols dryer off-gas

4. Insols dryer off-gas condensate 
5. Material held up in equipment removed for repair or replacement

6. Material held up in filters

All of the remaining traces of krypton, iodine, and xenon in the fissile kernels is expected to follow the off-gas stream, largely composed of sparge air. Less than $1 \%$ of the krypton and xenon and about $2 \%$ of the iodine from the fissile fraction is assumed to be present (Ref. 3-19), resulting in negligible concentrations in the off-gas stream.

As previously discussed, radon generation from U-232 is relatively steady state and requires equipment and batch sizing information to calculate release rates; therefore, radon is not projected for the material balance.

All of the tritium present is assumed to remain in solution (Ref. 3-19).

$\mathrm{NO}_{x}$ compounds are formed and released from the dissolver. For the material balance, an $80 \%$ scrubbing efficiency has been assumed in the reflux condenser (Ref. 3-19). About 300 1iters per day of $\mathrm{NO}_{\mathrm{x}}$ are assumed to enter the off-gas system for treatment in this study.

Table 3-4 indicates the assumed paths for heavy metals and some partially insoluble fission products in the dissolver solution and insols. Possible fission product eutectics formed in particle burning have not been projected in Table 3-4. All other fission and activation products and the boron are assumed to be in the product solution.

The insols drying operation has not been characterized and the off-gas flow is understated by the dryer off-gas contribution. Corrosion products and possible paths have not been projected. Fissile leaching corrosion rates would be expected to differ from fertile leaching due to the presence of more dilute nitric acid, the absence of fluoride, and a higher fission product concentration. 


\section{Special Nuclear Material Inventory}

Leaching product solution represents the first special nuclear material physical inventory point and the customer accountability point for fissile isotopes. Analytical measurement uncertainty on solutions containing a full range of fission products, activation products, and heavy metals will contribute to inventory uncertainty. Measurement accuracy limits for U-235 for HTGR fuels in a commercial plant have been proposed at 1\% (Ref. 3-27). Potential loss mechanisms in the fissile fraction leaching operation include material volatilized (or carried out with other volatiles) in the dissolver and/or dryer off-gas streams, material held up in equipment removed for repair or replacement, and material lost to waste with the silicon carbide hulls and other insolubles.

For the current study, $0.005 \%$ of the uranium and plutonium are assumed to be insoluble and $0.1 \%$ is assumed to be associated with the hulls. Special nuclear material possibly included in fission product eutectics from the burner is unknown and is not included.

In the material balance for the current study, burned-back fissile particles and fertile kernels in the insols would contain $0.1 \mathrm{~kg} \mathrm{U-235-}$ bearing uranium and $0.4 \mathrm{~kg} \mathrm{U}-233$-bearing uranium, respectively. The recoverable quantity will depend on particles broken in transport and on classifier efficiencies. The logistics of separating and identifying rework material may affect the customer accounting of reworked uranium. No projection has been made for material holdup in equipment and filters and loss to off-gas.

\subsubsection{Material Sampling}

A detailed sampling plan for HRDF reprocessing has not been prepared. Requirements are expected to include sampling for process control, effluent control, quality assurance (on solvent extraction products), customer accountability, and special nuclear material accountability and safeguards. 
In addition, since the $\mathrm{HRDF}$ is a demonstration plant, sampling for experimental data gathering may be a requirement. Required accuracy and turnaround times on analyses may vary according to sample purpose but are expected to be more stringent than current technology allows in order to meet the commercial production and throughput criteria for the HRDF. Since samples will also represent a special nuclear material loss mechanism, nondestructive test techniques and/or methods of returning the special nuclear material values contained in samples to process are desirable.

Development work is in progress at several National Laboratories, as well as at General Atomic, on measurement techniques, including at low concentrations. Most of the work is aimed at U-235; however, some measurement technique development for $\mathrm{U}-233$ is in progress, but mainly for refabrication. It is expected that hot engineering test representive sampling and analytical measurement operations will contribute significantly to pointing up areas requiring development for reprocessing. No program is currently planned for production line (fast turnaround) techniques for sampling, transport, and measurement for reprocessing.

\subsection{YIELDS AND THROUGHPUT SUMMARY - HEAD-END OPERATIONS}

\subsubsection{Reprocessing Throughput Summary}

HRDF reprocessing daily throughput will vary, depending on the type of fuel elements (or mix of types) being processed. A list of the various types is shown in Table 2-1. The effect of the fuel type on different process unit operations varies. For example, primary crushing depends on numbers of fuel elements and only slightly depends on their composition (type of graphite and control vs. standard elements). The primary burner operation is more dependent on composition (burnable carbon content, oxide vs. carbide fuels, and TRISO vs. BISO coatings) while classification, secondary crushing, and secondary burning are composition-dependent (quantities of particles, particle size and density distribution, and coating characteristics). Dissolution and solvent extraction depend on heavy meta1 and fission product content. 
Due to possible fuel design changes resulting from Lead Unit Plant studies that could make the material balances prepared for this study obsolete, only a single type of fuel element has been addressed: the LHTGR Standard Makeup Fuel Element. The characteristics of the fuel element assumed for this study are shown in Table 2-5. Detailed material balances based on 43 fuel elements per day average throughput are included in Ref. 3-1. The resulting product streams from head-end operations are shown in Table 3-5.

A summary of some of the pertinent variables in the average throughput is shown in Table 3-6. Approximations for other types of fuel elements can be determined by obtaining ratios from Tables 2-5 through Table 2-8 and applying the ratio to Table 3-6. For example, the uranium ratio in the fissile 23R element in Table 2-6 with reference to Table 2-5 is 0.16/0.22. Purex solvent extraction feed for 23R throughput is then $\sim 6.5 \mathrm{~kg}$ per day when the ratio is applied to Table 3-6. Similar detailed data may be obtained by ratioing any fuel element components as given in Ref. 3-7 (or Table 2-9) and applying the ratio to the detailed material balances as given in Ref. 3-1.

\subsubsection{Reprocessing Yields Summary}

The separation of HTGR fissile and fertile particles has two goals: (1) to provide a means of purging accumulated U-236 (a neutron poison) from the fuel cycle without undue penalties in loss of fuel values, and (2) to provide maximum recovery of fissile U-233 bred in the reactor to replace the need for fresh makeup U-235. The efficiency of particle separation within the processing plant and the ability to recover a maximum amount of useful fuel value in a purified form for refabrication affect HTGR economics. Definition of expected process performance is required to properly evaluate HTGR fuel cycles. The lack of representative irradiated HTGR fuel to obtain experimental verification of expected process yields precludes specific definition at this time. This study, therefore, has addressed establishing reasonable goals for fuel separation and recovery and the identification of ongoing experimental plans and target dates for experimental verification. 
TABLE $3-5$

LEACHER PRODUCT TO SOLVENT EXTRACTION

\begin{tabular}{|c|c|c|}
\hline & $\begin{array}{l}\text { Fertile } \\
\text { Leacher } \\
\text { Product }\end{array}$ & $\begin{array}{l}\text { Fissile } \\
\text { Leacher } \\
\text { Product }\end{array}$ \\
\hline Average liquid flow (1/day) (a) & 1479.6 & 1132.2 \\
\hline Heat load $(W / 1)^{(b)}$ & 5.1 & 5.0 \\
\hline Activity $(\mathrm{C} i / 1)$ & 1351.9 & 1145.6 \\
\hline Carbon $(g / 1)$ & 0.3 & 0.2 \\
\hline Uranium $(g / 1)$ & 7.3 & 8.0 \\
\hline Thorium $(g / 1)$ & 224.2 & NEGL \\
\hline Plutonium $(g / 1)$ & NEGL & 0.4 \\
\hline Fission products $(g / 1)$ & 7.3 & 15.5 \\
\hline Boron $(g / 1)$ & -- & 0.4 \\
\hline $\mathrm{HNO}_{3}(\underline{\mathrm{M}})$ & 8.4 & 2.0 \\
\hline $\mathrm{F}^{-}(\underline{\mathrm{M}})$ & 0.05 & -- \\
\hline $\mathrm{Al}^{++\overline{+}}(\underline{M})$ & 0.1 & -- \\
\hline $\mathrm{Cd}^{++}(\underline{\mathrm{M}})$ & 0.075 & 0.075 \\
\hline Total $\mathrm{NO}_{3}^{-}(\underline{M})$ & 13.0 & 2.5 \\
\hline
\end{tabular}

(a) Exclusive of rework material; based on 233 equivalent operating days/year, 43 standard makeup elements/day.

(b) Decay heat only. 
TABLE $3-6$
ASSUMED HRDF - PHASE I AVERAGE DAILY THROUGHPUT (KG OF FEED) (a)

\begin{tabular}{|c|c|c|c|c|c|c|}
\hline & $\begin{array}{c}\text { Fuel } \\
\text { Elements }\end{array}$ & $\begin{array}{l}\text { Fissile } \\
\text { Particles }\end{array}$ & $\begin{array}{c}\text { Fertile } \\
\text { Particles }\end{array}$ & $\begin{array}{c}\text { SiC } \\
\text { Hulls }\end{array}$ & Uranium & Thorium \\
\hline Crushing & 5098 & & & & & \\
\hline Primary burning & 5098 & & & & & \\
\hline Classifying & & 185 & 419 & 9 & & \\
\hline Fertile leaching & & 4 & 407 & & & \\
\hline Particle crushing & & 181 & 12 & 9 & & \\
\hline Particle burning & & 181 & 12 & 9 & & \\
\hline Fissile leaching & & 44 & 12 & 90 & & \\
\hline $\begin{array}{l}\text { Thorex solvent } \\
\text { extraction }\end{array}$ & & & & & 11 & 332 \\
\hline $\begin{array}{l}\text { Purex solvent } \\
\text { extraction }\end{array}$ & & & & & 9 & NEGL \\
\hline
\end{tabular}

(a) 43 standard makeup fuel elements per day $(10,000 /$ year $)$ of Philadelphia Electric unit type design. 
Classifier separation efficiency goals for LHTGR fuel (Ref. 3-19) are identified as:

1. $1.5 \mathrm{wt}-\%$ crossover of whole fertile kernels to the fissile stream.

2. 75 wt-\% crossover of broken fertile kernels to the fissile stream.

3. 2 wt-\% crossover of burned-back (to SiC coating) fissile particles to the fertile stream.

4. All of the broken fissile particles are assumed to follow the fissile stream.

Results of experimental classification studies at General Atomic (Ref. 3-31), summarized in Fig. 3-9, indicate that these goals are achievable, particularly with two-stage classification as recommended in the current flowsheet review (Ref. 3-1).

A fissile fraction leacher included after classification in the prior flow sheet review (Ref. 3-23) to recover fertile crossover material was removed because a significant percentage of broken fissile particles that could contaminate the solution with U-236 was identified. Fissile particle breakage will also contribute significantly to primary burner off-gas contamination and to fines recycle. Both fissile and fertile particle breakage are thus significant to a number of processes, as well as to ultimate special nuclear material recovery and overall yield. The particle breakage assumptions used in this study are summarized in Table 3-7. The assumed components of the breakage due to irradiation damage in the reactor are shown in Table 3-8. Breakage due to irradiated fuel handling is not included in the process projections; they are, instead, current design goals for cold fuel in the pilot plant. Adjustment in process projections for irradiated fuel differences will come from hot engineering test data and/or calculations. The breakage of the small percent of entrained crossover particles in each stream after the classifier will be important to the recovery of the 


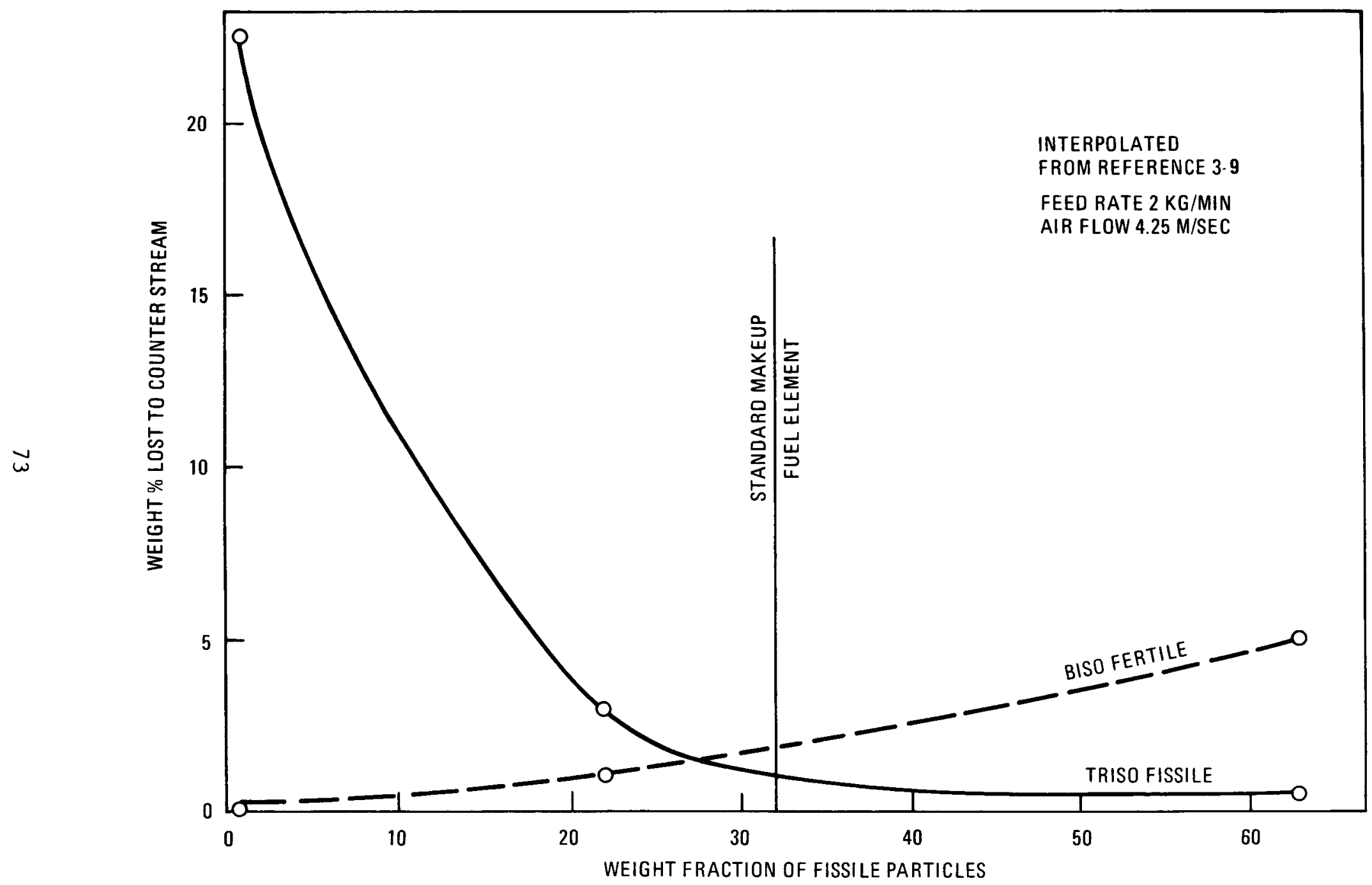

Fig. 3-9. Crossover of fuel particles vs weight fraction of fissile particles 
TABLE 3-7

DESIGN BASIS GOALS - PARTICLE BREAKAGE

\begin{tabular}{l|c|c|c}
\hline & \multicolumn{3}{|c}{ Percent } \\
\cline { 2 - 4 } & Fertile & Fissile & $\begin{array}{c}\text { Total } \\
\text { Particles }\end{array}$ \\
\hline Irradiation damage & 0.4 & 0.7 & 0.5 \\
Crushing & 0.8 & 2.6 & 1.3 \\
Transport (crush to burn) & 0.2 & 2.0 & 0.7 \\
Primary burn & 0.1 & 2.5 & 1.4 \\
plus fines recycle & 0.3 & 2.0 & 0.8 \\
Transport (burn to classify) & -- & 0.5 & 0.2 \\
Classify & 1.8 & 12.3 & 4.9 \\
\multicolumn{1}{c}{ Total } & & 2.0 & 4.3 \\
\hline
\end{tabular}


TABLE 3-8

SUMMARY OF PARTICLE BREAKAGE DUE TO IRRADIATION (a)

(\% of Total TRISO or BISO Particles)

\begin{tabular}{l|l|l}
\hline Particle Failure Mechanism & TRISO WAR UCO & BISO $^{\text {ThO }_{2}}$ \\
\hline Amoeba migration & 0.1 & Negligible \\
Fission product attack & Negligible & Negligible \\
Pressure vessel failure & 0.4 & 0.3 \\
Matrix-particle interaction & Negligible & Negligible \\
Manufacturing defects & 0.2 & 0.1 \\
Summary & 0.7 & 0.4 \\
\hline
\end{tabular}

(a) From Ref. 3-9. 
crossed-over material; however, no data currently exists on expected breakage for small quantities of particles in a large stream of particles of a different size and density.

While definitive process yields cannot be predicted until additional cold pilot plant and hot engineering test data are available, potential loss mechanisms for fissile U-233 and U-235 can be identified. Table 3-9 summarizes the potential loss mechanisms identified in this study, quantifying the potential loss where possible.

of the losses that can be quantified at this time, crossover particles represent the greatest potential loss. Therefore, the current flow sheet review (Ref. 3-1) has included concepts for the recovery of this material. Assessment of the recovery yield can probably be made in cold pilot material transport classification and dissolution studies.

Material holdup in equipment and filters may represent a significant factor in losses due to the multiplicity of possible holdup points. Development plans include sweepdown capability investigations and design requirements to minimize holdup. If necessary, provision can be made for collecting material from failed equipment in the HRDF for return to processing. Definition of in-situ cleanout capabilities over the next few years should identify any required recovery from failed equipment in order to allow provision in HRDF design. Plans are included in hot laboratory and hot engineering tests to quantify special nuclear material content of agglomerates possibly formed in fuel element and fuel particle burning so that recovery mechanisms can be provided if necessary. Analytical techniques can be specified and/or developed for HRDF that will allow the return of samples to processing.

Table 3-10 summarizes current development program plans and recommendations for obtaining needed data to predict and control yields and throughput rates for HRDF reprocessing head-end operations. 
TABLE 3-9

URANIUM LOSS PROJECTIONS - HRDF REPROCESSING

\begin{tabular}{|c|c|c|}
\hline Unit Operation & $\begin{array}{c}\text { Combined } \\
\text { U-235/U-233 } \\
\text { Loss }(\%)\end{array}$ & Basis \\
\hline Crushing & 0.001 & $\begin{array}{l}0.5 \% \text { material holdup } \\
\text { For first fuel element of a } \\
\text { customer batch (arbitrarily assumes } \\
\text { holdup equally distributed between } \\
\text { particles and graphite) }\end{array}$ \\
\hline $\begin{array}{l}\text { Material Transport } \\
\text { (Solids) }\end{array}$ & To be determined & $\begin{array}{l}\text { Holdup in transport lines for a } \\
\text { minimum of } 27 \text { transfers (see } \\
\text { Fig. 3-3) } \\
\text { Holdup in filters and hoppers for } \\
\text { a minimum of } 16 \text { storage locations } \\
\text { (see Fig. 3-3) }\end{array}$ \\
\hline Primary Burning & To be determined & $\begin{array}{l}<1 \mu \text { material loss to off-gas } \\
\text { Holdup in filters and equipment } \\
\text { Agglomerate content }\end{array}$ \\
\hline Particle Separation & 0.3 & $\begin{array}{l}\text { Fissile particles retired from } \\
320 \text { 25RS elements at equilibrium - } \\
\text { Phase II (Table 3-1) }\end{array}$ \\
\hline & 0.4 & $\begin{array}{l}\text { Fissile kernel crossover to } \\
\text { retired fissile stream at equili- } \\
\text { brium - Phase II (1.5\% of whole } \\
\text { kernels, } 75 \% \text { of broken kernels) } \\
\text { (Ref. 3-19) }\end{array}$ \\
\hline & To be determined & Holdup in equipment and filters \\
\hline Fertile Leaching & 0.004 & $\begin{array}{l}\text { Insoluble compounds based on } \\
\text { LWR } \mathrm{UO}_{2} \text { fuel dissolution results } \\
\text { (Table } 3-3 \text {, Ref. 3-25) }\end{array}$ \\
\hline & $<0.4$ & $\begin{array}{l}\text { Fissile particle crossover to } \\
\text { fertile particle stream-recovery } \\
\text { efficiency to be determined } \\
\text { (Table 3-3) }\end{array}$ \\
\hline $\begin{array}{l}\text { Secondary Crushing } \\
\text { and Burning }\end{array}$ & To be determined & $\begin{array}{l}\text { Agglomerate content } \\
\text { Equipment and filter holdup } \\
\text { Material loss to off-gas }\end{array}$ \\
\hline
\end{tabular}


TABLE 3-9 (Continued)

\begin{tabular}{|c|c|c|}
\hline Unit Operation & $\begin{array}{l}\text { Combined } \\
U-235 / U-233 \\
\text { Loss }(\%) \\
\end{array}$ & Basis \\
\hline \multirow[t]{4}{*}{ Fissile Leaching } & 0.02 & $\begin{array}{l}0.1 \% \text { of fissile fraction uranium } \\
\text { in hulls (Ref. } 3-30 \text { ) }\end{array}$ \\
\hline & 0.001 & $\begin{array}{l}\text { Insoluble compounds based on } \\
\text { LWR UO dissolution results } \\
\text { (Ref.3-25) }\end{array}$ \\
\hline & $<0.2$ & $\begin{array}{l}\text { Whole fissile particle content in } \\
\text { insols - recovery efficiency to } \\
\text { be determined (Table } 3-5 \text { ) }\end{array}$ \\
\hline & $<2.1$ & $\begin{array}{l}\text { Fertile kernel content in insols } \\
\text { from crossover - recovery } \\
\text { efficiency to be determined } \\
\text { (Table 3-5) }\end{array}$ \\
\hline A11 & To be determined & $\begin{array}{l}\text { Sampling losses due to archive } \\
\text { samples and destructive testing }\end{array}$ \\
\hline $\mathrm{A} 12$ & To be determined & $\begin{array}{l}\text { Decontamination waste streams for } \\
\text { equipment removed for repair or } \\
\text { replacement }\end{array}$ \\
\hline
\end{tabular}


TABLE 3-10

DEVELOPMENT PLAN INFORMATION AVAILABILITY FOR HRDF

(Applicable to Yields and Throughput)

\begin{tabular}{|c|c|c|c|}
\hline $\begin{array}{l}\text { Information } \\
\text { Required }\end{array}$ & & Development Recommendations & $\begin{array}{l}\text { Data } \\
\text { Available }\end{array}$ \\
\hline \multirow[t]{4}{*}{ Particle Breakage } & (1) & $\begin{array}{l}\text { Characterize cold pilot system particle breakage for typically } \\
\text { sized and coated BISO and TRISO particles in ratios expected for } \\
\text { various HRDF process operations (including crossover material } \\
\text { ratios) }\end{array}$ & $1977-1978$ \\
\hline & (2) & $\begin{array}{l}\text { Compare radioactive vs. nonradioactive particle breakage for } \\
\text { nontypical fuel in hot engineering test systems }\end{array}$ & $1985-1986^{(a)}$ \\
\hline & (3) & $\begin{array}{l}\text { Obtain strength calculations for irradiated and nonirradiated } \\
\text { LHTGR and FSV particles }\end{array}$ & TBD \\
\hline & (4) & $\begin{array}{l}\text { Extrapolate data from (2) and (3) to (1) to predict breakage } \\
\text { for HRDF }\end{array}$ & $\sim 1986$ \\
\hline \multirow{4}{*}{$\begin{array}{l}\text { Special Nuclear } \\
\text { Materia1 (SNM) } \\
\text { Holdup and Losses }\end{array}$} & & Filter Holdup & \\
\hline & (1) & $\begin{array}{l}\text { Characterize material holdup in filters for LHTGR fuel (heavy } \\
\text { metal vs. other) in cold pilot systems }\end{array}$ & $1977-1978$ \\
\hline & (2) & $\begin{array}{l}\text { Compare filter material held up for irradiated and nonirradiated } \\
\text { nontypical fuel in HET-Repro systems }\end{array}$ & $1985-1986$ \\
\hline & (3) & $\begin{array}{l}\text { Extrapolate (2) to (1) to project HRDF holdup and need to recover } \\
\text { SNM for holdup }\end{array}$ & $\sim 1986$ \\
\hline
\end{tabular}

(a) Assumes summary data available at the end of hot engineering tests. 
TABLE 3-10 (Continued)

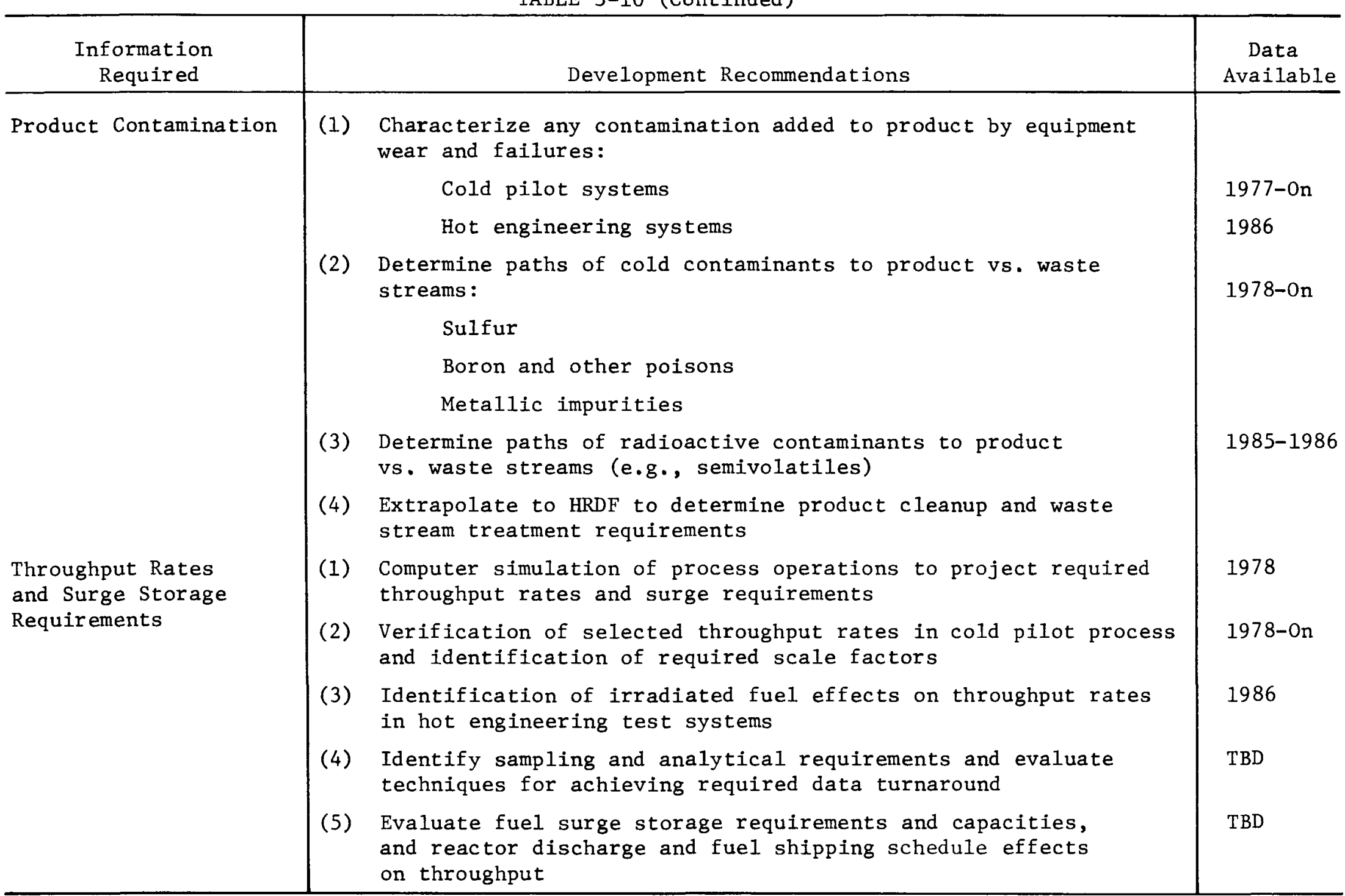


TABLE 3-10 (Continued)

\begin{tabular}{|c|c|c|c|}
\hline $\begin{array}{l}\text { Information } \\
\text { Required }\end{array}$ & & Development Recommendations & $\begin{array}{c}\text { Data } \\
\text { Available }\end{array}$ \\
\hline $\begin{array}{l}\text { Special Nuclear } \\
\text { Materia1 (SNM) } \\
\text { Holdup and Losses, } \\
\text { (Continued) }\end{array}$ & $\begin{array}{l}\text { (1) } \\
(2) \\
(3) \\
(4) \\
(1) \\
(2) \\
(3) \\
(4)\end{array}$ & $\begin{array}{l}\text { Equipment Holdup } \\
\text { Determine degree of equipment cleanout achievable in cold pilot } \\
\text { systems for LHTGR fuel } \\
\text { Characterize material remaining in failed equipment (heavy metal } \\
\text { vs. other) in cold pilot systems for LHTGR fuel } \\
\text { Compare degree of cleanout and characterize material holdup for } \\
\text { irradiated and nonirradiated nontypical fuel in HET-Repro systems } \\
\text { Extrapolate ( } 3 \text { ) to (1) and (2) to project SNM losses to HRDF and } \\
\text { determine need for recovery of decontamination materials } \\
\text { Crossover Material Recovery } \\
\text { Characterize classification efficiency for insols } \\
\text { Characterize particle breakage in various ratios of crossover } \\
\text { streams in transport } \\
\text { Establish fertile particle dissolution rate in fissile dissolver } \\
\text { Characterize uranium in hulls and agglomerates for LHTGR fuel } \\
\text { to determine need for recovery }\end{array}$ & $\begin{array}{l}1977-1978 \\
1977-1978 \\
1985-1986 \\
\sim 1986\end{array}$ \\
\hline
\end{tabular}




\subsection{YIELDS AND MATERIAL THROUGHPUT - OFF-GAS TREATMENT}

Figure 3-10 is a simplified block diagram of the proposed off-gas treatment system for HRDF. Details are given in Ref. 3-1.

Off-gas treatment systems are being evaluated and will be separately reported under Task 200 of the Thorium Utilization Program. Information in this report represents only minor updating of Task 200 work reported in Ref. 3-18. The following summary addresses only the major assumptions incorporated in the material balances accompanying the HRDF flow sheet review (Ref. 3-1).

Table 3-1l summarizes the relative off-gas compositions assumed for this study of head-end operations. Releases in various operations are based on particle breakage projections in Table 3-7. Rework of whole particles in the insols is not included in the material balance, resulting in several < $100 \%$ release assumptions. Assumptions necessary for radon release calculations are discussed in detail in Section 3.2.3 under "Waste Stream and Contaminant Paths." Table 2-9 quantifies the radioactive contaminants on a per-fuel-element basis and can be used with Table 3-11 to assess average daily input to the off-gas treatment system for any desired number of standard makeup elements. The percentages shown on Table 3-11 should not be applied to 23R, 25R, and FSV elements because many of the percentages will change when the ratio of fissile to fertile particle content changes (see Tables 2-5 to 2-7).

Table 3-12 summarizes the decontamination factors (DF) and/or conversion and reduction efficiencies for the various off-gas treatment systems assumed for material balances in Ref. 3-1. The simplifying assumption was made that the DF for a given contaminant applied only to its specific treatment unit, while, in reality, removal of a contaminant may occur in more than one system. It should be emphasized that the DFs for iodine and tritium are goals and do not necessarily represent current state of the art (Ref. 3-32). 


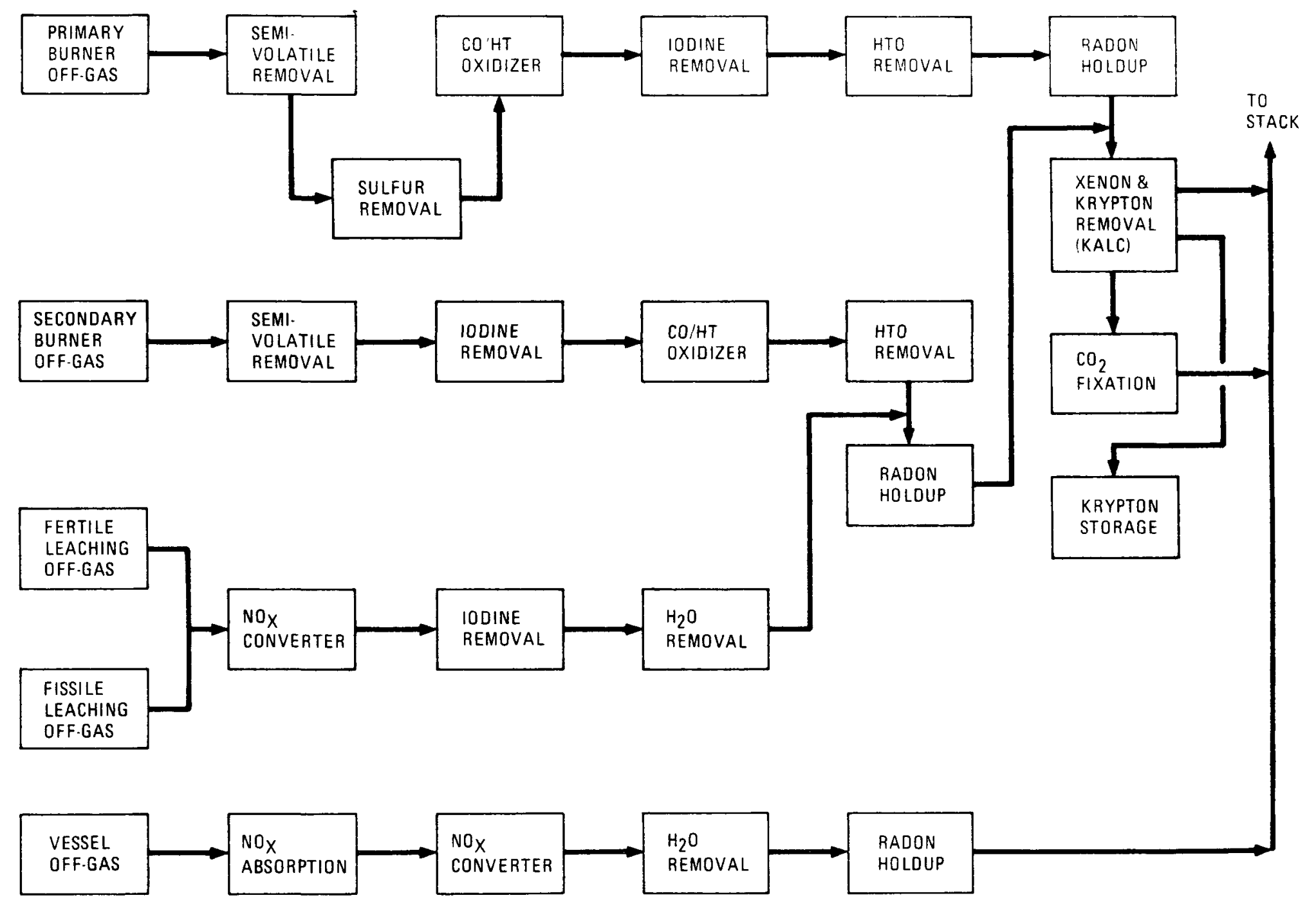

Fig. 3-10. Proposed reprocessing off-gas treatment scheme (Ref. 3-1) 
TABLE 3-11

ASSUMED OFF-GAS DISTRIBUTION FROM HRDF HEAD-END OPERATIONS

\begin{tabular}{|c|c|c|c|c|c|c|c|c|c|c|c|}
\hline & \multirow{2}{*}{$\begin{array}{c}\% \text { of } \\
\text { Tota } 1 \\
\text { Off-Gas } \\
\end{array}$} & \multicolumn{10}{|c|}{ Percent of Total } \\
\hline & & $\mathrm{CO}$ & ${ }^{14} \mathrm{C}$ & $\mathrm{I}_{2}$ & $\mathrm{Kr}$ & $\mathrm{Xe}$ & Sulfur & Radon & $\mathrm{NO}_{\mathbf{x}}$ & $3 \mathrm{H}$ & $\mathrm{sV}^{(\mathrm{a})}$ \\
\hline Primary Burning & 93.3 & 80.5 & 90.6 & 6.0 & 9.9 & 9.9 & 98.1 & $\mathrm{TBD}$ & -- & 75.7 & TBD \\
\hline Secondary Burning & 3.2 & 19.5 & 0.4 & 31.0 & 45.4 & 56.4 & $\mathrm{TBD}$ & TBD & -- & 0.1 & TBD \\
\hline Fertile Leaching & 3.1 & -- & -- & 58.6 & 40.8 & 30.3 & -- & $\mathrm{TBD}$ & 80.0 & -- & TBD \\
\hline Fissile Leaching & 0.4 & -- & -- & 0.7 & 0.5 & 0.5 & -- & TBD & 20.0 & - & TBD \\
\hline Total & 100.0 & 100.0 & $91.0^{(b)}$ & $96.3^{(b)}$ & $96.6^{(c)}$ & $97.1^{(c)}$ & $98.1^{(d)}$ & $\mathrm{TBD}^{(\mathrm{e})}$ & 100.0 & $75.8^{(f)}$ & $(g)$ \\
\hline
\end{tabular}

(a) Balance in dissolver solution and undissolved particles.

(b) Balance to fertile dissolver solution.

(c) Balance in undissolved particles.

(d) Balance in fissile fraction TBD whether in off-gas or solution.

(e) Randon release calculations require detailed batch sizing and operating mode definition beyond the scope of this study.

(f) Balance in dissolver solution and undissolved particles.

(g) Semivolatiles (e.g., Ru, Cs, Rb, Tc, Te, $\mathrm{Zr}, \mathrm{Nb}, \mathrm{Sb}, \mathrm{Ce}, \mathrm{Se}-$ all in solution or insols for this study). 
TABLE 3-12

OFF-GAS TREATMENT ASSUMPTION

\begin{tabular}{|c|c|c|}
\hline Treatment Unit & $\begin{array}{c}\text { Decontamination } \\
\text { Factor }\end{array}$ & $\begin{array}{c}\text { Unit } \\
\text { Efficiency }\end{array}$ \\
\hline $\begin{array}{l}\text { Semivolatile Removal } \\
\text { Sulfur Removal } \\
\text { CO/HT Oxidation } \\
\text { Iodine Removal } \\
\text { Tritium Removal } \\
\text { NO Conversion } \\
\text { KALC System } \\
\text { Absorber/Fractionator/Stripper }\end{array}$ & 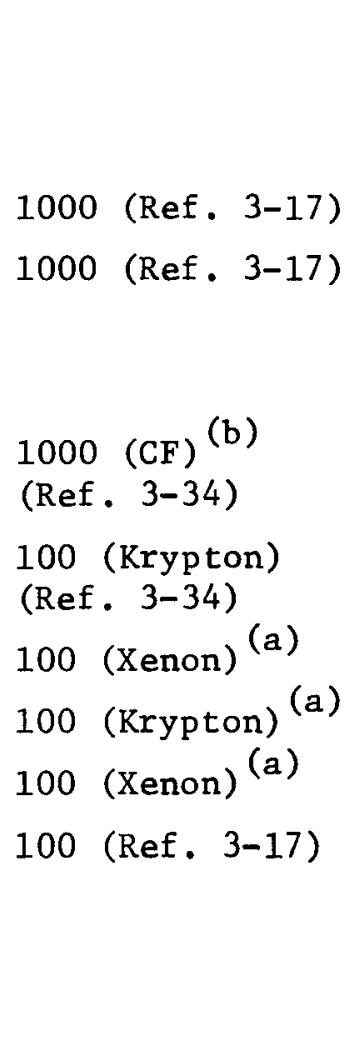 & $\begin{array}{l}\text { TBD } \\
95 \% \text { (a) } \\
98 \% \text { (Ref . 3-33) } \\
99 \%(\operatorname{Ref} \cdot 3-17)\end{array}$ \\
\hline
\end{tabular}

(a) Arbitrary assignment.

(b) Concentration factor $=\frac{\text { Other Gases Per Unit } \mathrm{Kr} \text { In }}{\text { Other Gases Per Unit } \mathrm{Kr} \text { Out }}$. 
Table 3-13 summarizes material balance information on secondary burner (Stream 164) and combined leacher off-gas (Stream 528). The activity levels, heat loads, and flow rates of the two streams can be seen to be of the same order of magnitude. The two streams are, therefore, combined for radon holdup and sent to the KALC process (Fig. 3-10). The alternative of separately removing $\mathrm{CO}_{2}$ from Stream 164 for $\mathrm{CO}_{2}$ fixation would result in decreasing the gas flow rate and greatly increasing the fission product concentration; therefore, it seems reasonable to combine the streams. The air from the leacher off-gas will be largely removed in KALC concentration and not increase the $\mathrm{CO}_{2}$ treatment gas throughput significantly.

Table 3-14 summarizes the off-gas release to the stack resulting from the above assumptions for head-end operations.

\subsection{YIELDS AND MATERIAL THROUGHPUT - SOLVENT EXTRACTION}

Figures 3-11 and 3-12 are simplified block diagrams of the proposed Thorex and Purex solvent extraction systems for HRDF. Conventional process flow diagrams are shown in GA-A14319 (Ref. 3-1).

Developmental work on both Thorex and Purex systems for process refinement and equipment definition is currently in progress at General Atomic. Several simplifying assumptions have been made in the material balance based on results of the developmental program (Refs. 3-35, 3-12). Table 3-15 summarizes the separation factors for uranium from thorium and for thorium from uranium and the fission product decontamination factors assumed for Thorex solvent extraction. The uranium losses assumed in preparing the material balances are also 11sted. Table 3-16 presents similar information for Purex solvent extraction.

The assumptions for the Thorex cycles reflect cold pilot development work at General Atomic using zirconium tracers. Verification of the assumptions in the presence of high levels of activity from a mixture of fission products will not be avallable until hot engineering tests (Ref. 3-4) are complete (about 1985). 
TABLE $3-13$

SECONDARY BURNER OFF-GAS AND LEACHER OFF-GAS TO TREATMENT

\begin{tabular}{|c|c|c|c|}
\hline Stream Number & $\begin{array}{c}\text { To Radon } \\
\text { Holdup } \\
\text { Unit From } \\
\text { SBOG } \\
164 \\
\end{array}$ & $\begin{array}{l}\text { To Radon } \\
\text { Holdup } \\
\text { Unit From } \\
\text { LoG } \\
528\end{array}$ & $\begin{array}{c}\text { To KALC } \\
\text { Process } \\
166\end{array}$ \\
\hline Type of Flow & Batch & Semi-Cont. & Semi-Cont. \\
\hline Average Operating $\mathrm{Hr} /$ Day ${ }^{(\mathrm{a})}$ & 24 & 24 & 24 \\
\hline $\begin{array}{l}\text { Average Gas Flow } \\
(\text { SLPD/1000) }(b)\end{array}$ & 419.4 & $>456.7$ & $>876.1$ \\
\hline Heat Load $\left(\right.$ Watts/l) ${ }^{(c)}$ & $>3.4(-5)$ & $<4.1(-5)$ & $<3.7(-5)$ \\
\hline Activity $(\mathrm{Ci} / \mathrm{l})$ & $>2.2(-2)$ & $<2.7(-2)$ & $<2.5(-2)$ \\
\hline $\mathrm{O}_{2}(\mathrm{SLPD} / 1000)$ & 48.9 & & 48.8 \\
\hline $\mathrm{CO}_{2}(\mathrm{SLPD} / 1000)$ & 370.0 & & 370.0 \\
\hline CO (SLPD/1000) & 0.4 & & 0.4 \\
\hline $\mathrm{NO}_{x}(\mathrm{SLPD} / 1000)$ & & 0.003 & 0.003 \\
\hline AIR (SLPD/1000) & & $>456.4$ & $>456.4$ \\
\hline $\mathrm{NH}_{3}(\mathrm{SLPD} / 1000)$ & & 0.006 & 0.006 \\
\hline $\mathrm{N}_{2}(\mathrm{SLPD} / 1000)$ & & 0.3 & \\
\hline Sulfur $(g / \ell)$ & TBD & & TBD \\
\hline Carbon-14（g/l) & $2.3(-9)$ & & $<1.1(-9)$ \\
\hline Radon $(g / \ell)$ & TBD & TBD & TBD \\
\hline Tritium $(g / l)$ & $4.8(-11)$ & & $<2.3(-11)$ \\
\hline Krypton $(g / l)^{(d)}$ & $8.7(-4)$ & $<7.0(-4)$ & $<8.0(-4)$ \\
\hline Xenon $(g / \ell)$ & $8.0(-3)$ & $<4.0(-3)$ & $<5.9(-3)$ \\
\hline Iodine $(g / \ell)$ & $2.1(-7)$ & $<3.7(-7)$ & $<3.9(-7)$ \\
\hline Other FP $(\mathrm{g} / \ell)$ & TBD & TBD & TBD \\
\hline Other Particulates $(\mathrm{g} / \mathrm{l})$ & TBD & & TBD \\
\hline
\end{tabular}

(a) Exclusive of rework - based on 233 equivalent operating days per year.

(b) Exclusive of filter blowback and bed regeneration $\mathrm{CO}_{2}$ additions. Not including impurities.

(c) Decay heat only (exclusive of process heating or cooling).

(d) Volume of krypton $\sim 200$ liters (volume not previously considered). 
TABLE $3-14$

ASSUMED DAILY OFF-GAS TO STACK

(Standard Makeup Elements)

\begin{tabular}{|c|c|c|c|c|}
\hline Component & $\begin{array}{l}\text { From } \\
\text { KALC }\end{array}$ & $\begin{array}{c}\text { From } \\
\mathrm{CO}_{2} \\
\text { Fixation }\end{array}$ & $\begin{array}{l}\text { From } \\
\text { KALC } \\
\text { or } \mathrm{CO}_{2} \\
\text { Fixation }\end{array}$ & Remarks \\
\hline $\mathrm{O}_{2}$ (SLPD) & Neg1. & 115,100 & & \\
\hline $\mathrm{CO}_{2}$ (SLPD) & Neg1. & $1,328,400$ & & \\
\hline CO (SLPD) & Neg1. & 28,800 & & \\
\hline Air (SLPD) & Negl. & 321,000 & & \\
\hline Krypton (SLPD) & 2 & 200 & & \\
\hline Xenon (SLPD) & 1000 & 1,000 & & \\
\hline $\mathrm{NO}_{\mathrm{x}}$ (SLPD) & Neg1. & 3 & & \\
\hline $\mathrm{NH}_{3}$ (SLPD) & Negl. & 6 & & \\
\hline Carbon-14 & Negl. & & $2 \times 10^{-2}$ & \\
\hline Radon (g) & TBD & TBD & & \\
\hline Tritium (g) & TBD & TBD & $\left.2 \times 10^{-4}\right\}$ & Requires definition \\
\hline Iodine $(\mathrm{g})$ & TBD & TBD & $\left.4 \times 10^{-1}\right\}$ & $\begin{array}{l}\text { of paths in KALC } \\
\text { process }\end{array}$ \\
\hline Other FP & $\mathrm{TBD}$ & TBD & & $\begin{array}{l}\text { Requires definition } \\
\text { of semivolatile } \\
\text { content and paths }\end{array}$ \\
\hline Other Particulates & $\mathrm{TBD}$ & TBD & & $\begin{array}{l}\text { Requires definition } \\
\text { of particulate con- } \\
\text { tent and paths }\end{array}$ \\
\hline Activity (Ci) & 2 & 251 & & \\
\hline
\end{tabular}




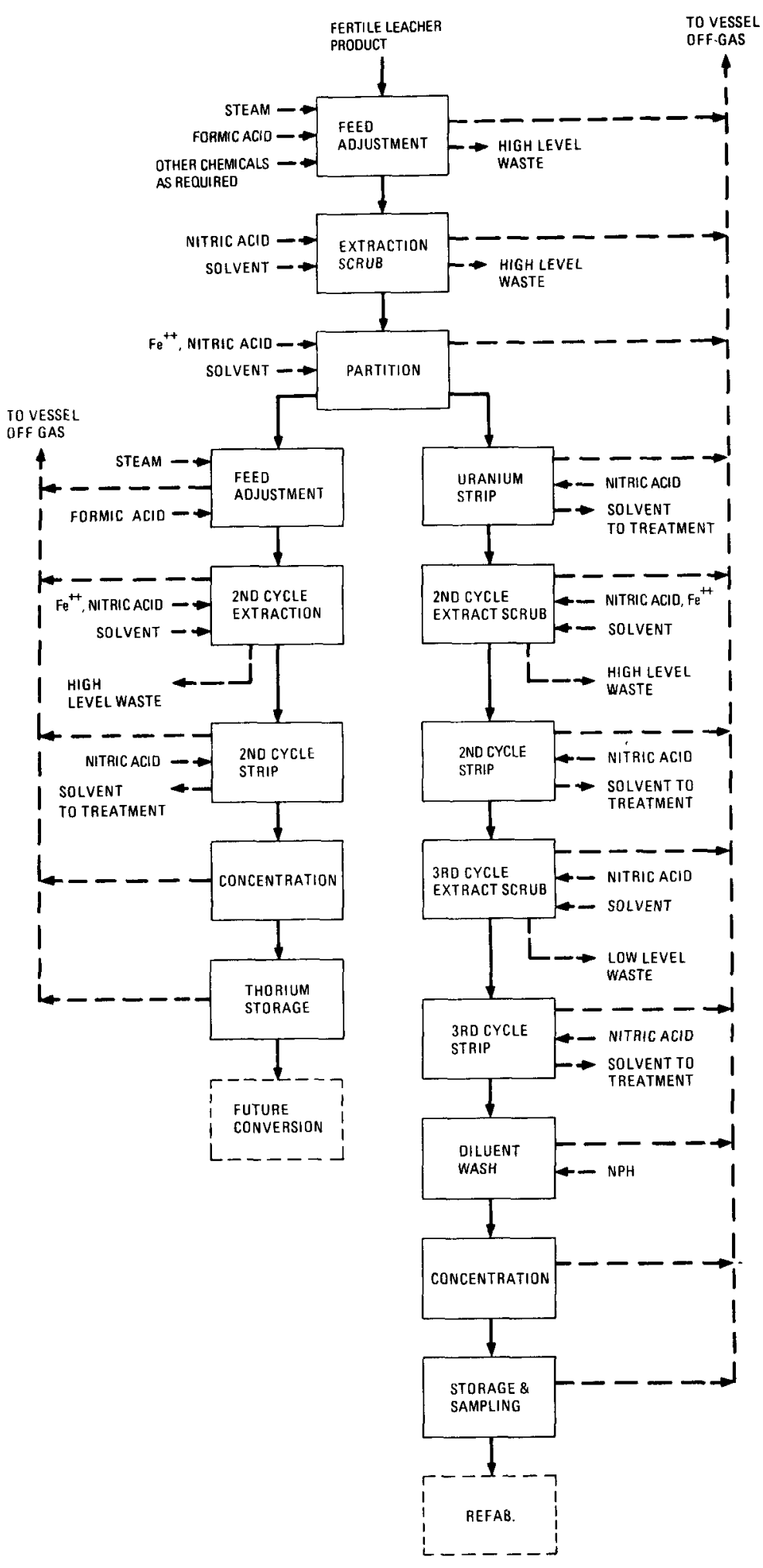

Fig. 3-11. Thorex solvent extraction diagram 


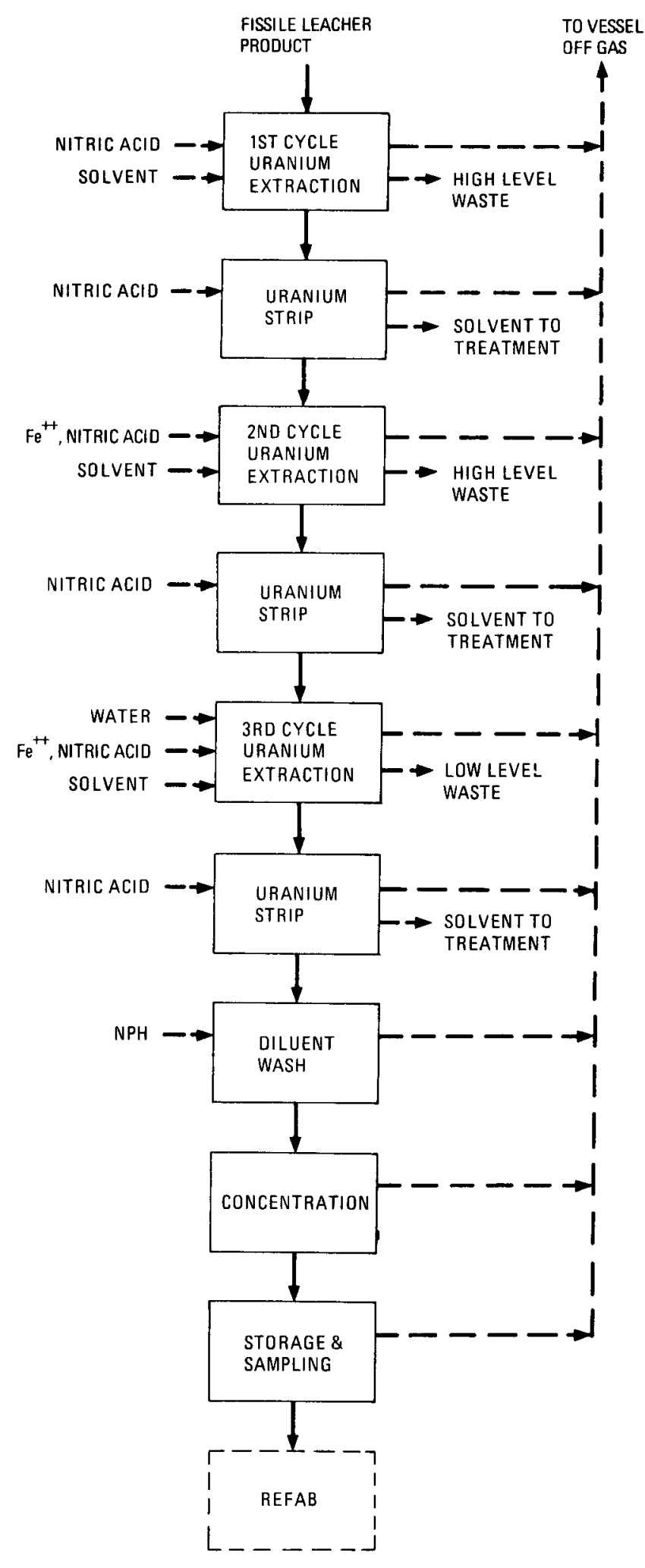

Fig. 3-12. Purex solvent extraction diagram 
TABLE 3-15

THOREX SOLVENT EXTRACTION ASSUMPTIONS $(\mathrm{a})$

\begin{tabular}{|c|c|c|c|}
\hline Process Step & $\begin{array}{l}\text { Fission Product } \\
\text { Decontamination/ } \\
\text { U/Th Separation } \\
\text { Factor Assumed }\end{array}$ & $\begin{array}{c}\text { Uranium Loss } \\
\text { Assumed (b) } \\
(\%)\end{array}$ & Comments \\
\hline Feed Adjustment & None & None & $\begin{array}{l}0.67 \mathrm{H}^{+} / \mathrm{Th} \text { mol ratio in } \\
\text { product }\end{array}$ \\
\hline First Cycle Extraction & $\mathrm{DF}-10,000$ & 0.1 & $\begin{array}{l}\text { DF based on fission product/ } \\
\text { thorium ratio }\end{array}$ \\
\hline Th/U Partition & $\begin{array}{l}U \text { from } T h-10^{4} \\
T h \text { from } U-10^{3}\end{array}$ & 0.3 & $\begin{array}{l}\text { Assume } 5 \% \text { of FPs follow IBU } \\
\text { stream }\end{array}$ \\
\hline Uranium Strip & & & Remaining thorium removed \\
\hline Second Cycle Uranium & $\mathrm{DF}-100$ & 0.2 & $\begin{array}{l}\text { Overall factors for entire } \\
\text { cycle }\end{array}$ \\
\hline Third Cycle Uranium & $\mathrm{DF}-100$ & 0.2 & $\begin{array}{l}\text { Assume DF and recovery } \\
\text { identical to second cycle }\end{array}$ \\
\hline Second Cycle Thorium & $D F-100$ & 0.1 & $\begin{array}{l}\text { Thorium loss also assumed to } \\
\text { be } 0.1 \%\end{array}$ \\
\hline
\end{tabular}

(a) $\operatorname{Ref}$. 3-35.

(b) Rework and recovery from waste not considered. Overall total recovery with rework is expected to be $99.9 \%$.

(c) $0.2 \%$ used for material balance. 
TABLE 3-16

PUREX SOLVENT EXTRACTION ASSUMPTIONS

\begin{tabular}{|c|c|c|c|}
\hline Process Step & $\begin{array}{l}\text { Fission Product } \\
\text { Decontamination } \\
\text { Factor Assumed }\end{array}$ & $\begin{array}{c}\text { Uranium Loss } \\
\text { Assumed (a) } \\
(\%)\end{array}$ & Comments \\
\hline $\begin{array}{l}\text { First Cycle Extract. } \\
\text { and Strip }\end{array}$ & 1000 & 0.13 & $\begin{array}{l}\text { Overall factor } \\
\text { for cycle }\end{array}$ \\
\hline Second Cycle & 500 & 0.15 & $\begin{array}{l}\text { Overall factor } \\
\text { for cycle }\end{array}$ \\
\hline Third Cycle & 100 & 0.05 & $\begin{array}{l}\text { Overall factor } \\
\text { for cycle }\end{array}$ \\
\hline
\end{tabular}

(a) Loss assumed excluding rework. Overall recovery factor is expected to be $99.9 \%$. 
The Purex decontamination factors are assumed to be similar to those for Thorex and loss factors are more optimistic. However, verification of the assumptions for high-burnup fuel is not expected until hot engineering tests are completed.

The application of the assumptions in the solvent extraction material balance to the leacher streams shown in Table 3-5 results in solvent extraction products as shown in Table 3-17. The leacher product stream average daily flows are based on the net 233 days per year operation in the head-end systems. The solvent extraction systems are assumed to operate for 263 days per year (no customer accountability requirements since customer accounts are closed in head-end). The average daily flow of the solvent extraction feed streams is accordingly adjusted from the leacher product streams. Sufficient surge storage to allow continuous solvent extraction operation is assumed to be available. Surge storage requirements and process coupling feasibility will be determined in computer simulations of operating modes performed under a separate task.

The product streams shown in Table 3-17 do not reflect the recovery of uranium from high-level waste and represent a total uranium loss of $2.6 \%$ in the Thorex line and $0.4 \%$ in the Purex line. The target goal for solvent extraction, including rework and waste recycle, is $99.9 \%$ recovery of uranium values.

Section 4 compares the solvent extraction product assumptions with current refabrication feed specifications (Ref. 3-36).

\section{REFERENCES}

3-1. Abraham, L., and N. Holder, "Reprocessing Flow Sheet Review and Material Balance," General Atomic Report GA-A14319, to be published.

3-2. Baxter, B. J., et al., "Conceptual Design for a Prototype Fuel Element Size-Reduction System Designated UNIFRAME," ERDA Report GA-A13275, General Atomic Company, September 1, 1975. 
TABLE $3-17$

SOLVENT EXTRACTION PRODUCT

\begin{tabular}{l|l|l|l}
\hline & $\begin{array}{c}\text { From Thorex } \\
\text { Solvent Extraction } \\
\text { to Refabrication }\end{array}$ & $\begin{array}{c}\text { From Thorex } \\
\text { Solvent Extraction } \\
\text { to Th Storage }\end{array}$ & $\begin{array}{c}\text { From Purex } \\
\text { Solvent Extraction } \\
\text { to Refabrication }\end{array}$ \\
\hline Average Liquid Flow (1/day) (a) & 40 & 624 & 17 \\
Head Load (watts/1) (b) & 0.1 & 0.002 & Neg1 \\
Activity & Neg1 (d) & 0.007 & 0.05 \\
From fission products (Ci/1) & 2.2 & Neg1 \\
From U (Ci/1) & Neg1 & 0.002 & Neg1 \\
From Th (Ci/1) & 233 & 0.04 & 470 \\
Uranium (g/1) & Trace $(\mathrm{d})$ & 464 & Neg1 \\
Thorium (g/1) & -- & Neg1 & Trace \\
Other Heavy Metal (g/1) & Negl & Trace & Trace \\
Fission Products (g/1) & 0.25 & 0.5 & 0.2 \\
HNO M &
\end{tabular}

(a) Exclusive of rework material. Based on 263 equivalent operating days per year; 10,000 spent standard makeup fuel elements processed per year.

(b) Decay heat.

(c) Based on activity level for $\mathrm{Th}$, U, or fission products given in Ref. 3-7. Does not account for decay time during processing.

(d) "Trace" designates concentration in the range of $10^{-5}$. "Negligible" designates $\geq 10^{-6}$. 
3-3. "National Program Plan for HTGR Fuel Recycle Development," United States Energy Research and Development Administration, October 1976.

3-4. Goedde1, W. V., "Status Report: (A) Milestones (B) Agreements and Commitments (C) Critical Items, Month Ending November 30, 1976; Thorium Utilization Program, P.A. 53," General Atomic Company, unpublished data.

3-5. Union Carbide Corporation (UCC-ND), et al., "Criteria Document for HTGR Fuel Recycle Hot Engineering Test," Vol. III, October 1976.

3-6. Vaughan, V. C., "Release of Kr During HTGR Fuel Element Crushing for Off-Gas SDD Support," Oak Ridge National Laboratory, unpublished data, November $11,1974$.

3-7. Hamilton, C. J., et al., "HTGR Spent Fuel Composition and Fuel Element Block Flow," Volumes I and II, General Atomic Report GA-A13886, July 1976.

3-8. Strand, J. B., "Activity Plans-Fuel Element Size Reduction," General Atomic Company, unpublished data, October 14, 1976.

3-9. Shenoy, A. S., and D. W. McEachern, "HTGR Core Thermal Design Methods and Analysis," General Atomic Report GA-A12985, December 31, 1974.

3-10. Strand, J., "Engineering Change Notice, Fuel Element Size Reduction System Design Criteria," General Atomic Company, unpublished data, December 1976.

3-11. "Thorium Utilization Program Quarterly Progress Report for the Period Ending August 31, 1976," ERDA Report GA-A14085, General Atomic Company, September 30, 1976.

3-12. Richards, P. C., "HRDF Gas Requirements for Pneumatic Conveying and Classification," General Atomic Company, unpublished data, October $28,1976$.

3-13. De Lesdernier, D., "Activity Plan: Prototype Solids Handling System," General Atomic Company, unpublished data, August 23, 1976.

3-14. Carney, H. C., and V. H. Pierce, "Burner Cyclical Operations in a Commercial HTGR Reprocessing Facility," General Atomic Company, unpublished data, July 23, 1975.

3-15. Young, D. T., "Proposed HRDF Primary Burner Operating Cycle," General Atomic Company, unpublished data, November 2, 1976. 
3-16. Young, D. T., "Demonstration of the HRDF Primary Burner Operating Cycle," General Atomic Company, unpublished data, September 22, October 11, 1976.

3-17. Pence, D. T., "Airborne Effluent Control for HTGR Fuel Reprocessing Plants," General Atomic Report GA-A13929, May 1976.

3-18. "Thorium Utilization Program Quarterly Progress Report for the Period Ending November 30, 1976," ERDA Report GA-A14214, General Atomic Company, December 1976.

3-19. Park, U. S., "HRDF Head-End Material Balance," General Atomic Company, unpublished data, November 1, 1976.

3-20. Fitzgerald, C. L., and C. L. Vaughen, "Information and Data for HTGR Fuel Burner Off-Gas Streams: Final Response to Program Request," Allied Chemical Corporation Report ACC-ORNL-3, May 1975.

3-21. "Technical Progress Report, November 1976," Allied Chemical Corporation Report HL-28-76, November 10, 1976.

3-22. Zimmerman, R. D., and J. S. Rode, "Design Criteria: $40 \mathrm{~cm}$ Prototype Fluidized-Bed Crushed Fuel Element Burner," General Atomic Company, unpublished data, January 23, 1976.

3-23. "Thorium Utilization Program Quarterly Progress Report for the Period Ending May 31, 1976," ERDA Report GA-A13949, General Atomic Company, June 30, 1976.

3-24. Abraham, L., et a1., "Flowsheet Review for Production Reprocessing and Production Refabrication Requirements," General Atomic Report GA-A13751, to be published.

3-25. Vondra, B. L., "LWR Fuel Reprocessing and Recycle Program Quarterly Report for Period July 1 to September 30, 1976," ERDA Report ORNL/TM-5660, Oak Ridge National Laboratory.

3-26. Vondra, B. L., "LWR Fuel Reprocessing and Recycle Program Quarterly Report for Period April 1 to June 30, 1976," ERDA Report ORNL/TM5547, Oak Ridge National Laboratory.

3-27. Hogan, James, P., General Atomic Company, unpublished data, April $18,1973$.

3-28. "Activity Plan - Fuel Particle Crusher," General Atomic Company, unpublished data, August 10, 1976. 
3-29. Shefcik, J. J., "A Review of the HTGR Reprocessing Off-Gas Treatment Development Requirements," General Atomic Company, unpublished data, August 10, 1976.

3-30. Lin, K. H., "Characteristics of Radioactive Waste Streams Generated in HTGR Fuel Reprocessing," ERDA Report ORNL-TM-5096, Oak Ridge National Laboratory, January 1976.

3-31. De Lesdernier, D. L., "Pneumatic Classification of the TRISO/BISO Fuel Blend," General Atomic Company, unpublished data, May 15, 1975.

3-32. "LWR Fuel Reprocessing and Recycle Progress Report for July 1 through September 30, 1976," Idaho Chemical Processing Plant Report ICP-1108, December 1976.

3-33. "HTGR Fuel Reprocessing Facility System Design Description for offGas Cleanup System," SSD 1.3A, Allied Chemical Corporation, June 1975.

3-34. Kasten, R. R., et a1., "Gas-Cooled Reactor Program, Annua1 Progress Report for the Period Ending December 31, 1972," ERDA Report ORNL4911, Oak Ridge National Laboratory, March 1974.

3-35. Reddick, G. W., "Solvent Extraction in HTGR Reprocessing, Interim Development Report," ERDA Report GA-A13835, General Atomic Company, February 1976.

3-36. Trauger, D. B., "Thorium Utilization Program: Interim II Specifications for Uranyl Nitrate Feed Solution to the Resin-Loading Process," Oak Ridge National Laboratory, unpublished data, December $15,1976$. 


\section{COMPARISON OF REPROCESSING YIELDS WITH PRODUCT SPECIFICATION}

Interim specifications for uranyl nitrate feed solution to the resinloading fabrication process have been prepared by Oak Ridge National Laboratory (Ref, 4-1). Table 4-1 lists the specification maximum limits for the major categories of impurities, an average spent fuel element impurity concentration, and the solvent extraction decontamination factor (DF) required to reduce the spent fuel concentration to values within the specification limits. The required DFs are well within the fission product DF goals given in Tables $3-15$ and 3-16 for process operations and the expected heavy metal separation factors and DFs. However, several uncertainties in the impurity concentrations indicate that it would be prudent to include the third cycle cleanup in both the Purex and Thorex uranium extraction flow sheet. As indicated in footnote (k) in Table 4-1, a number of impurities expected to be present in the spent fuel are not included in the specification, but do significantly contribute to the total boron equivalent content and will certainly contribute to the required DF. Process impurities, including equipment corrosion and erosion products, are not considered in Table 4-1. In addition, spent fuel concentrations may vary significantly from the expected average. Concentration variations coupled with as yet unproven DFs for high-burnup fuel result in a threecycle. flow sheet recommendation for both Purex and Thorex uranium extraction.

A thorium specification does not currently exist; however, a tentative specification proposed in a previous flow sheet review (Ref. 4-2) is shown in Table 4-2. The product thorium stream shown in Table 3-17 appears to acceptably meet the specification except for uranium content. The product projection is based on current cold development work (Ref. 4-1) and does not necessarily reflect the final separation factor that can be achieved in HRDF. In addition, the acceptable level of U-232 contamination in the thorium must still be determined in order to define whether $<25$ ppm uranium is indeed a requirement. 
TABLE 4-1

IMPURITY CONCENTRATIONS AND REQUIRED SOLVENT EXTRACTION DECONTAMINATION FACTORS

(Excluding Impurities Added in Processing)

\begin{tabular}{|c|c|c|c|c|c|}
\hline \multirow[b]{3}{*}{ Element } & \multirow{3}{*}{$\begin{array}{l}\text { Specification } \\
\text { Max. Limit } \\
(\mu g / g \text { U) (a) }\end{array}$} & \multicolumn{2}{|c|}{$\begin{array}{c}\text { Spent Fue1 Element }(\mathrm{b}) \\
\text { Concentration }(\mu \mathrm{g} / \mathrm{g} \mathrm{U})\end{array}$} & \multirow{2}{*}{\multicolumn{2}{|c|}{ DF Required }} \\
\hline & & \multirow{2}{*}{$\begin{array}{l}\text { Fertile } \\
\text { Stream }\end{array}$} & \multirow{2}{*}{$\begin{array}{l}\text { Fissile } \\
\text { Stream }\end{array}$} & & \\
\hline & & & & Thorex & Purex \\
\hline Aluminum & 75 & - & -- & -- & -- \\
\hline $\begin{array}{l}\text { Calcium plus } \\
\text { Magnesium }\end{array}$ & 150 & -- & -- & -- & -- \\
\hline $\begin{array}{l}\text { Chlorine plus } \\
\text { Fluorine }\end{array}$ & 50 & $1,224^{(c)}$ & -- & $0^{(d)}$ & $0^{(\mathrm{d})}$ \\
\hline Chromium & 150 & -- & -- & -- & -- \\
\hline Cobalt & 75 & $2 \times 10^{-3}$ & $1 \times 10^{-4}$ & 0 & 0 \\
\hline Copper & 200 & -- & -- & -- & -- \\
\hline $\begin{array}{l}\text { Iron plus } \\
\text { Chromium }\end{array}$ & 200 & - & -- & -- & -- \\
\hline Lead & 200 & 160 & $3 \times 10^{-2}$ & 0 & 0 \\
\hline Manganese & 200 & -- & -- & -- & -- \\
\hline Molybdenum & 200 & 117,118 & 277,525 & 600 & 1,400 \\
\hline Nickel & 150 & 7,298 & 586 & 50 & 4 \\
\hline Phosphorus & 200 & $5 \times 10^{-3}$ & $2 \times 10^{-5}$ & $0^{(\mathrm{d})}$ & $0^{(\mathrm{d})}$ \\
\hline Silicon & 200 & -- & $--(e)$ & -- & $0^{(\mathrm{e})}$ \\
\hline Sulfur & 30 & $78,027^{(c)}$ & 31 & $0^{(\mathrm{d})}$ & $0^{(\mathrm{d})}$ \\
\hline Tantalum & 200 & -- & -- & -- & -- \\
\hline Tin & 200 & 341 & 473 & 2 & 3 \\
\hline Titanium & 200 & -- & -- & -- & -- \\
\hline Tungsten & 200 & -- & -- & -- & -- \\
\hline Vanadium & 200 & - & -- & -- & -- \\
\hline Zinc & 200 & $-\infty$ & -- & $\underline{--}$ & -- \\
\hline $\begin{array}{l}\text { Total of Above } \\
\text { Elements }\end{array}$ & $\overline{1,200}$ & $\overline{204,168}$ & $\overline{278,615}$ & $\overline{200}$ & $\overline{250}$ \\
\hline
\end{tabular}


TABLE 4-1 (Continued)

\begin{tabular}{|c|c|c|c|c|c|}
\hline \multirow[b]{3}{*}{ Element } & \multirow{3}{*}{$\begin{array}{l}\text { Specification } \\
\text { Max. Limit } \\
(\mu \mathrm{g} / \mathrm{g} U)(\mathrm{a})\end{array}$} & \multicolumn{2}{|c|}{$\begin{array}{r}\text { Spent Fuel Element } \\
\text { Concentration }(\mu \mathrm{g} / \mathrm{g} \mathrm{U})\end{array}$} & \multirow{2}{*}{\multicolumn{2}{|c|}{ DF Required }} \\
\hline & & \multirow{2}{*}{$\begin{array}{l}\text { Fertile } \\
\text { Stream }\end{array}$} & \multirow{2}{*}{$\begin{array}{l}\text { Fissile } \\
\text { Stream }\end{array}$} & & \\
\hline & & & & Thorex & Purex \\
\hline Plutonium & $\begin{array}{l}30(\mathrm{U}-233) \\
3(\mathrm{U}-235)\end{array}$ & 91 & 47,050 & 3 & 15,700 \\
\hline Thorium & 600 & $3 \times 10^{7}$ & $2 \times 10^{-1}$ & $50^{(\mathrm{f})}$ & \\
\hline $\begin{array}{l}\text { Total Impurities, } \\
\text { Burnable }(\mathrm{g})\end{array}$ & $20 \operatorname{TEBC}^{(h)}$ & $63,893^{(h, i)}$ & $56,131^{(h)}$ & 3,200 & 2,800 \\
\hline $\begin{array}{l}\text { Total Impurities, } \\
\quad \text { Nonburnable }(j)\end{array}$ & $2 \operatorname{TEBC}{ }^{(h)}$ & $1,318^{(h)}$ & $3,745^{(h)}$ & $700^{(k)}$ & $1,900^{(\mathrm{k})}$ \\
\hline other ${ }^{(k)}$ & None & $1 \times 10^{6}$ & $2 \times 10^{6}$ & $0^{(k)}$ & $0^{(\mathrm{k})}$ \\
\hline
\end{tabular}

(a) Reference 4-1.

(b) Reference 4-3; standard makeup fuel element (cooled 180 days).

(c) Quantity includes contribution from graphite in fuel element.

(d) Element is assumed to volatilize during burning step.

(e) Silicon is expected to be disposed of as hulls as a product of burning. Only a negligible residue should be in solution.

${ }^{(f)} D F$ of 50 required after separation factor of 1000 for thorium from uranium is applied.

(g) Burnable elements include boron, cadmium, 1ithium, samarium, gadolinium (Ref. 4-1).

(h) $\mathrm{TEBC}=$ total equivalent boron content.

(i) Includes boron from poison wafers.

(j) Nonburnable elements include aluminum, barium, calcium, chlorine, chromium, cobalt, copper, iron, indium, manganese, molybdenum, nickel, phosphorus, silicon, silver, tin, tungsten, vanadium, zinc, europium, dysprosium.

(k) Other impurities present in fuel but with no specification limit in Ref. 4-1 include 37 fission and activation products. TEBC $\cong 1365$ (fertile) and 3241 (fissile). The TEBC is principally attributable to neodymium and technicium. Assuming the maximum limit of 2 TEBC for nonburnable impurities applies would increase the required DF for Thorex from 700 to $\sim 1350$ and for Purex from 1900 to 23500 . 
TABLE 4-2

TENTATIVE THORIUM PRODUCT SPECIFICATIONS FOR STORAGE

\begin{tabular}{l|l}
\hline Thorium & $2.1 \pm 0.1 \mathrm{M}$ Th $\left(\mathrm{NO}_{3}\right)_{4}$ \\
$\mathrm{NO}_{3}^{-} / \mathrm{Th}$ & $4<\mathrm{NO}_{3}^{-} / \mathrm{Th}<4.5$ \\
Uranium & $<25 \mathrm{ppm}$ \\
Plutonium & $<10 \mathrm{ppm}$ \\
$\begin{array}{l}\text { Residual } \beta-\gamma \text { activity } \\
>0.06 \mathrm{MeV}\end{array}$ & $<20 \mathrm{Ci} / 1 \quad(2 \mathrm{M}$ Th solution) \\
\hline
\end{tabular}

(a) Corresponds to a fission product (and $\mathrm{Pa}-233$ ) DF greater than 200 from average spent fuel. 
REFERENCES

4-1. Trauger, D. B., "Thorium Utilization Program: Interim II Specifications for Uranyl Nitrate Feed Solution to the Resin-Loading Process," Oak Ridge National Laboratory, unpublished data, December 15, 1976.

4-2. Abraham, L., et al., "Flowsheet Review for Production Reprocessing and Production Refabrication Requirements, General Atomic Report GA-A13751, to be published.

4-3. Strand, J. B., "Activity Plans - Fuel Element Size Reduction," General Atomic Company, unpublished data, October 14, 1976. 
TABLES (Continued)

2-7. Spent fuel element definition - TBV (average LHTGR U-235 recycle element; TRISO UC $\mathrm{X}_{\mathrm{y}}$ fissile; $\mathrm{BISO} \mathrm{ThO}_{2}$ fertile). • . 23

2-8. Range of average values for $\mathrm{UC}_{\mathrm{x}} \mathrm{O}$ fissile and $\mathrm{ThO}_{2}$ fertile particles for LHTGR . . . . . . . . . . . . . . 25

2-9. Major fission products, heavy metals, and other contaminants in projected HRDF throughput (per fuel element). . . . . 26

3-1. Average annual uranium throughput $(\mathrm{kg})$ at equilibrium reprocessing operation. . . . . . . . . . . . . . . 34

3-2. Assumed distribution of heavy metals, fission products, and insolubles in fertile fraction dissolution. . . . . . . . 53

3-3. Particle burner typical off-gas flow. . . . . . . . . 60

3-4. Assumed distribution of heavy metals, fission products, and insolubles in fissile fraction leaching . . . . . . . . . . . 64

3-5. Leacher product to solvent extraction . . . . . . . . 70

3-6. Assumed HRDF - Phase I average daily throughput ( $\mathrm{kg}$ of feed )...................... 71

3-7. Design basis goals - particle breakage. . . . . . . . . . 74

3-8. Summary of particle breakage due to irradiation . . . . . . 75

3-9. Uranium loss projections - HRDF reprocessing. . . . . . . . 77

3-10. Development plan information availability for HRDF. . . . . 79

3-11. Assumed off-gas distribution from HRDF head-end operations. 84

3-12. Off-gas treatment assumption. . . . . . . . . . . . 85

3-13. Secondary burner off-gas and leacher off-gas to treatment . 87

3-14. Assumed daily off-gas to stack. . . . . . . . . . . 88

3-15. Thorex solvent extraction assumptions . . . . . . . . . . 91

3-16. Purex solvent extraction assumptions. . . . . . . . . . 92

3-17. Solvent extraction product. . . . . . . . . . . . . 94

4-1. Impurity concentrations and required solvent extraction decontamination factors . . . . . . . . . . . . . 99

4-2. Tentative thorium product specifications for storage. . . . 101 